


\title{
THE EVOLUTION OF METASOMATIC URANIUM ORE SYSTEMS IN THE CENTRAL MINERAL BELT OF LABRADOR
}

\author{
By \\ Charlene Duffett \\ A thesis submitted to the \\ Faculty of Graduate and Post Doctoral Affairs
}

in partial fulfillment of the requirements for the degree of

Master of Science

Carleton University

Ottawa, Ontario

September, 2019 
The undersigned recommended to the Faculty of Graduate and Post Doctoral Affairs acceptance of this thesis

THE EVOLUTION OF METASOMATIC URANIUM ORE SYSTEMS IN THE CENTRAL MINERAL BELT OF LABRADOR

Submitted by Charlene Duffett in partial fulfilment of the requirement of the degree Master of Science.

Dr. Brian Cousens, Thesis Supervisor, Chair

Department of Earth Sciences 


\section{Abstract}

In quantitative LA-ICP-MS maps of uraninite from the Kitts-Post Hill belt in Central Labrador, remobilization of $U$ and LREE along grain boundaries/fractures support the varying degrees of alteration recorded in major/trace element chemistry. Primary uraninite contains elevated $\mathrm{Th}, \mathrm{Zr}$, and REE contents implying crystallization from high-temperature fluids capable of transporting HFSE. Altered grains are characterized by elevated Zr, low Th and low REE contents, indicating potential remobilization in response to regional tectonic-magmatic events. In chondritenormalized plots of uraninite, contrasting REE signatures imply three populations, formed under different temperatures/physico-chemical conditions. Magnetite geochemistry reveals at least two events, characterized by both magmatic-like $\mathrm{V}$ contents, and hydrothermal $\mathrm{Ni} / \mathrm{Cr}$ ratios. The inferred contrasting fluid sources, reflected in the major/trace element compositions, reveal a fluid history complicated by post-ore magmatism and metamorphism. Potential syn-uranium mineralization hydrothermal zircon grains from the Kitts and Gear deposits were analyzed by SHRIMP and record isotopic re-setting ca. 1800 Ma. 


\section{Acknowledgements}

I would like to first thank my supervisor Eric Potter for his guidance and encouragement during my years at the Geological Survey of Canada, I honestly could not have asked for a better supervisor. Brian Cousens is thanked for his supervision and unlimited advice during this project.

To Pedro Acosta-Gongora for his help in the field, knowledge of the area and systems and help with paper 1 of this study, it was invaluable. To Greg Sparkes and Glenn Penney of the Newfoundland and Labrador Geological Survey for their knowledge and support during my field work. To Louise Corriveau for her expertise in IOAA systems, her short course was incredible and it was a huge help during the writing of this thesis, all in only two days.

To Nunatukavut for their financial support during my studies, nakummek. To the Research Affiliate Program of the Government of Canada for their continued funding throughout this project. Duane Petts for his expertise with the laser and data processing. Pat Hunt, Chris Koblynski, Katherine Venance, Glenn Poirier and Bill Davis for all their work and expertise in the labs and Chris Lawley and Alex Zagorevski for their constructive reviews and edits. Finally to my friends and family for their unconditional support throughout my studies. 


\section{Preface}

This is a paper-based thesis and therefore there are some repetitions throughout the dissertation - in the Abstracts, Introduction, Methods and Conclusion sections of the paper and the thesis. The thesis is comprised of five chapters: an introduction; three chapters of results; and a conclusion. Chapter 2 is the manuscript for the first paper of this thesis.

The student is the lead author of chapter 2 (paper 1), the co-authors are Eric Potter, Duane Petts, Pedro Acosta-Góngora, Brian Cousens and Greg Sparkes. The student was the main contributor in data acquisition, background research and analyzing results.

In the first paper (chapter 2), we determined that remobilization due to metasomatic fluids have affected the uranium mineralization at the Kitts deposit, and that REE chondrite normalized patterns of uraninite are more susceptible to changes due to fluids than previously thought.

In chapter 3, LA-ICP-MS element maps revealed that that magnetite of the KittsPost Hill belt has characteristics of both magmatic Fe-Ti-V magnetite and hydrothermal magnetite. In chapter 4, SHIRMP zircon U-Pb geochronology revealed that remobilization of the uranium mineralization of the Kitts deposit possibly occurred ca. 1800 Ma.

We will submit paper 1 (chapter 2 ) to Ore Geology Reviews. We have modified the figure and table captions to be consistent throughout the thesis. 
Table of Contents

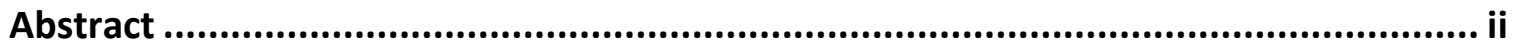

Acknowledgements ................................................................................... ii

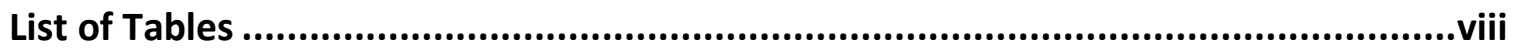

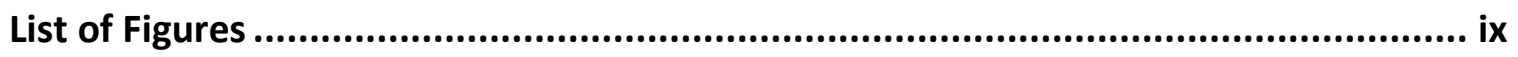

List of Appendices ..................................................................................

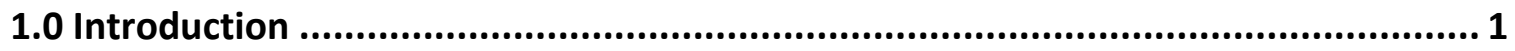

2.0 The evolution of metasomatic uranium ore systems in the Kitts-Post Hill belt of the

Central Mineral Belt, Labrador.........................................................................6 6

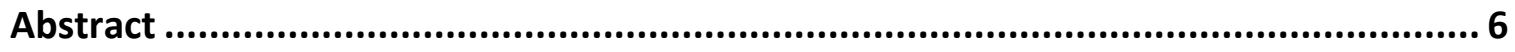

2.1 Introduction ..................................................................................... 7

2.1.1 IOAA systems evolution ........................................................... 10

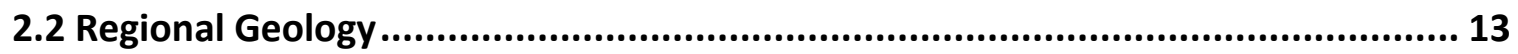

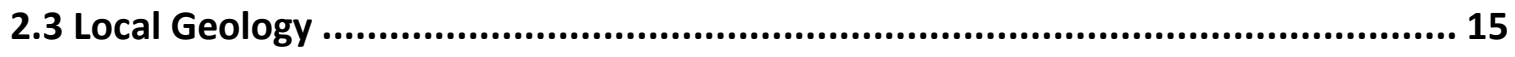

2.3.1 Uranium genetic classification ........................................................... 18

2.3.2 Deposits of the Kitts-Post Hill belt.................................................. 19

2.3.3 Timing of uranium mineralization................................................ 22

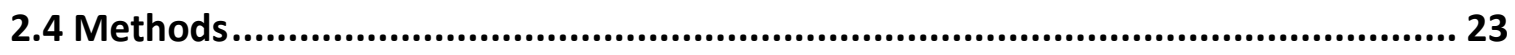

2.4.1 Rock collection and mineral identification ....................................... 23 


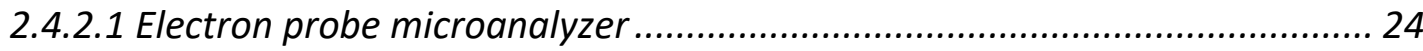

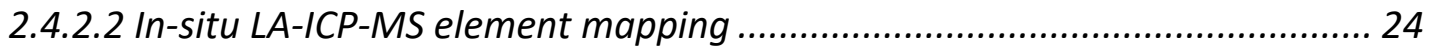

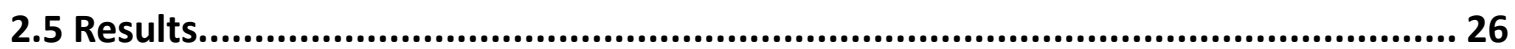

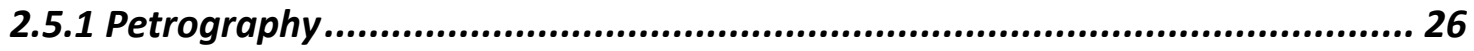

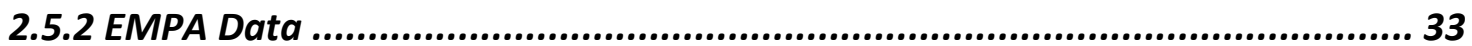

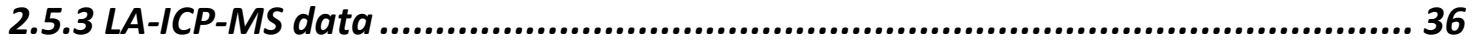

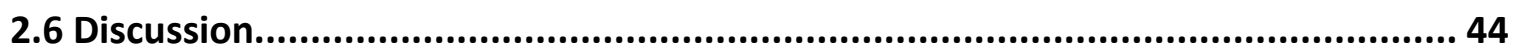

2.6.1 IOAA facies in the Kitts-Post Hill belt ............................................... 44

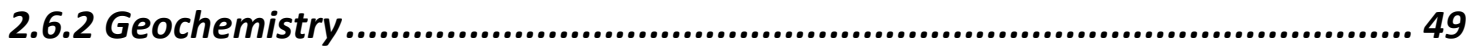

2.6.3 Mineralization in terms of regional tectono-metamorphic history................ 55

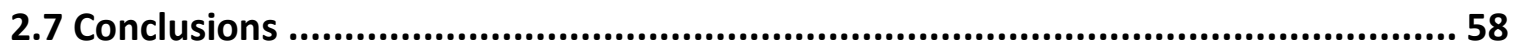

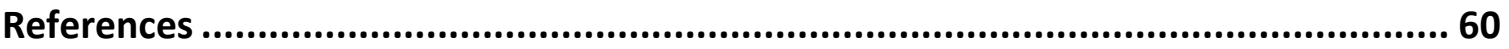

3.0 Magnetite geochemistry of the Kitts-Post Hill belt of the Central Mineral Belt,

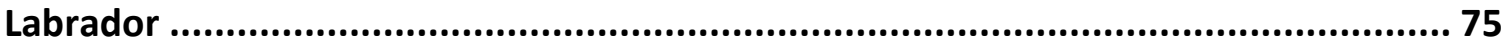

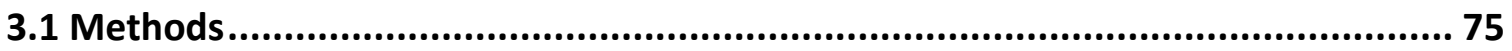

3.1.1 Rock collection and mineral identification ........................................... 75

3.1.2 In-situ LA-ICP-MS element mapping............................................ 76

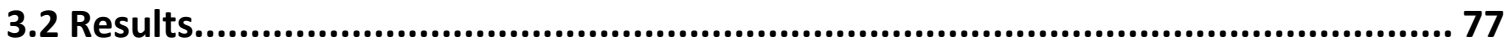




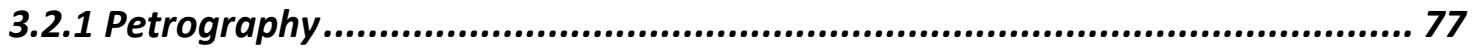

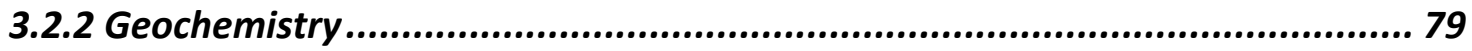

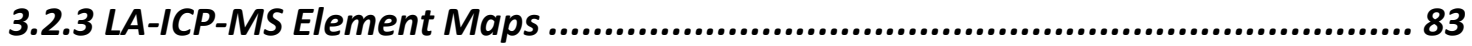

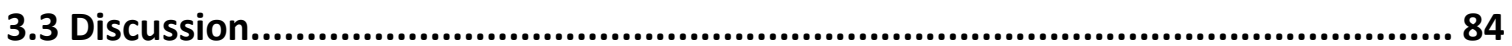

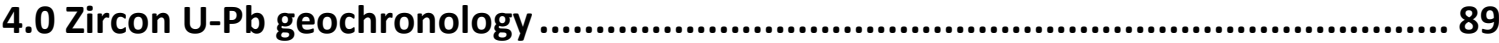

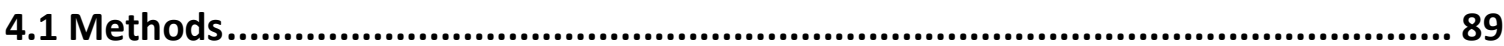

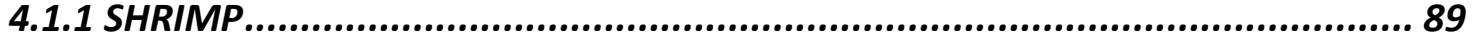

4.1.2 Electric pulse disaggregation ............................................................... 90

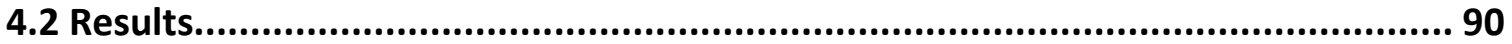

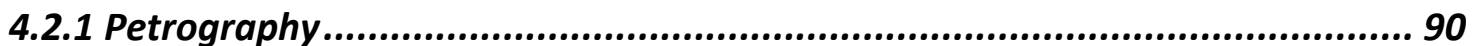

4.2.2 Zircon SHRIMP geochronology...................................................... 93

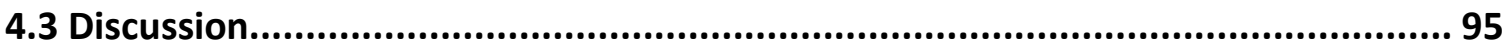

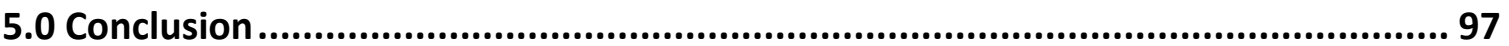

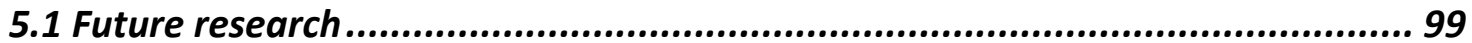

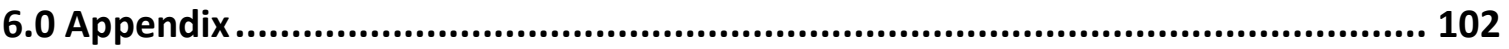

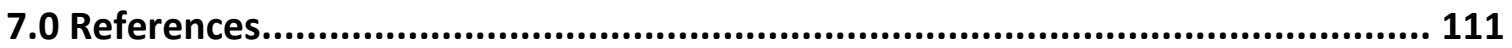




\section{List of Tables}

Table 2-1: Location, drill hole and lithology information for the samples described ...... 28

Table 2-2: Petrography of samples representative of alteration and mineralization within the sample suite. Abbreviations: amphibole (amp), andradite (adr), apatite (ap), arsenopyrite (aspy), biotite (bio), calcite (cal), chalcopyrite (cpy), clinozoisite (clz), epidote (ep), galena (gal), hematite (hem), ilmenite (ilm), K-feldspar (K-spar), magnetite (mag), molybdenite (moly), monazite (mnz), plagioclase (plag), pyrite (py), pyroxene (pxn), quartz (qz), titanite (ttn), and uraninite (urn). 30

Table 2-3: Silicate EMPA data in wt \% (* denotes average composition) 34

Table 2-4: Average uraninite compositions in wt\% from each sample area

Table 2-5: Representative trace element data of uraninite from LA-ICP-MS (in ppm), filtered to lower detection limits. Top row is the sample number, second row gives the location number analyzed on the sample.

Table 2-6: Average REE contents of Mistamisk uraninite compared to analyses by Lach et al. (2013). Analyses by LA-ICP-MS in this study, with error reported in 1 standard

deviation $(\sigma)$

Table 3-1: LA-ICP-MS data (ppm) of magnetite used to create Fig. 3-2. Abbreviations:

minimum (min); first quartile (Q1); median (med); third quartile (Q3); maximum $(\max )$

Table 4-1: SHRIMP zircon geochronology data, corrected for common ${ }^{204} \mathrm{~Pb}$ 94 


\section{List of Figures}

Fig. 1-1: Summary table of the alteration and mineralization of IOAA systems where depth is correlated to temperature (after Corriveau et al., 2010, 2016, 2018). Abbreviations: High temperature (HT); low temperature (LT); hematite (hem); magnetite (mag).

Fig. 2-1: (a) Location and geology of Labrador; (b) Geology of the Central Mineral Belt area, with locations of deposits and showings of uranium mineralization, modified from

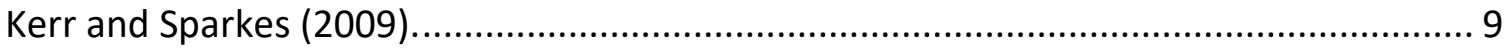

Fig. 2-2: Geology of the Post Hill group near the Kitts-Post Hill belt, modified from Sparkes (2017).

Fig. 2-3: Simplified cross section of the Kitts-Post Hill deposits; a) Kitts; b) Gear; c) Inda;

and d) Nash. Modified from Sparkes (2017). 20

Fig. 2-4: Generalized paragenetic sequence of the deposits within the Kitts-Post Hill trend, weight of lines indicate relative abundance, dashed lines represent uncertainty in the sequence. Abbreviations: amphibole (amp), arsenopyrite (aspy), biotite (bio), chalcopyrite (cpy).chlorite (chl), clinozoisite (clz), epidote (ep), hematite (hem), Kfeldspar (K-spar), magnetite (mag), molybdenite (moly), pyrite (py), pyroxene (pxn) and, stilpnomelane (stilp). 29

Fig. 2-5: Backscatter electron (BSE) images of (a) fine-grained uraninite in veinlet cutting albite, amphibole and magnetite; sample 18-CD-10. (b) Fine-grained uraninite in amphibole, plagioclase and K-feldspar crosscut by late iron oxide veinlet; sample GS-08266. (c) Uraninite in amphibole, plagioclase, quartz, K-feldspar and stilpnomelane; 
sample GS-08-267, (d) Coarse-grained uraninite veinlet crosscutting plagioclase and amphibole; sample 18-CD-14b. (e) Fine-grained uraninite in matrix of K-feldspar and chlorite; sample 17-CD-024. (f) Fine-grained amphibole veinlet crosscutting plagioclase, rimmed by fine-grained uraninite, molybdenite, titanite and monzonite; sample CD-17-

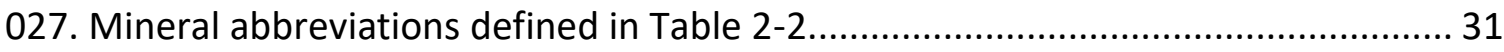

Fig. 2-6: BSE images of (a) coarse-grained pyrite with inclusions of amphibole in matrix of plagioclase, juxtaposed against a matrix of pyroxene and andradite, which is being cross-cut by veinlet of fine-grained plagioclase; Sample 17-CD-09. (b) Clinozoisite and magnetite veinlet crosscutting matrix of plagioclase, amphibole, K-feldspar and calcite; Sample 17-CD-17. (c) Amphibole and garnet matrix hosting a plagioclase veinlet, that is host to fine-grained REE mineralization; Sample 17-CD-09. (d) Veinlet of fine-grained stilpnomelane with minor molybdenite, titanite and ilmenite crosscutting plagioclase matrix; Sample GS-08-268. (e) Fine-grained andradite veinlet crosscutting plagioclase, biotite/chlorite and K-feldspar, overprinted by magnetite; Sample 17-CD-10. (f) Coarsegrained amphibole-titanite-iron-oxide veinlet crosscutting plagioclase, K-feldspar and biotite matrix; Sample 17-CD-76. Mineral abbreviations defined in Table 2-2.

Fig. 2-7: Chondrite normalized REE plots for uraninite from the Kitts deposit (black lines), plotted against data from the Mistamisk veins of Quebec (orange lines, this study), Nori deposit of the Great Bear magmatic zone (blue lines, Potter et al., 2014, accepted), Kawanga deposit of Zambia (red lines, Mercadier et al., 2011), and Domes region of Zambia respectively (green lines, Eglinger et al., 2013). 
Fig. 2-8: LA-ICP-MS element maps of coarse-grained uraninite and pyrite in albite and amphibole from sample 18-CD-014b (Group 1) of the Kitts deposit.

Fig. 2-9: LA-ICP-MS element maps of a fine-grained uraninite veinlet cutting amphibole and quartz from sample GS-08-267 (Group 3) of the Kitts deposit. 43

Fig. 2-10: LA-ICP-MS element maps of coarse-grained uraninite in albite, K-feldspar, amphibole and quartz from sample GS-08-267 (Group 3) of the Kitts deposit, highlighting the remobilization of $\mathrm{U}(\mathrm{b}), \mathrm{Pb}(\mathrm{c})$ and $\mathrm{La}(\mathrm{g})$ from uraninite along fractures.

Fig. 2-11: LA-ICP-MS element maps of fine-grained uraninite-monazite-molybdenite veinlets cutting albite, amphibole and K-feldspar from sample 17-CD-27 (Group 3) of the Kitts deposit.

Fig 2-12: IOCG alteration discrimination plot of Montreuil et al. (2013) combined with the molar proportion "bar codes" of Corriveau et al. (2018) illustrating: (a) the composition of unaltered rock types selected from published data modified from Potter et al. (in press) and (b) the presence of IOAA facies in the Kitts-Post Hill trend. Reference rock types from: 1 - Keleman et al. (2014); 2 - Gale et al. (2003); 3 to 6 - Keleman et al. (2014); 7 -Rudnick and Gao (2014); 8 \& 10 - Kemp and Hawkesworth (2005); 9 - Rudnick and Gao (2014); 11 \& 12 - Pearce et al. (1984) 48

Fig. 2-13: REE sum (wt \%) versus U/Th of samples analyzed by LA-ICP-MS, modified from Frimmel et al. (2014). 50

Fig. 2-14: Chemical U-Pb ages for uraninite grains analyzed by EMPA, color-coded to corresponding sample numbers. Ages calculated using Bowles (2015) 
Fig. 3-1: BSE image of (a) alternating lamellae of fine-grained amphibole and plagioclase with minor quartz and magnetite with disseminated uraninite; Sample 18-CD-10 of the Inda deposit. (b) Fine grained matrix of amphibole and plagioclase with disseminated magnetite and titanite; Sample 18-CD-16 of the Gear deposit. Abbreviations: amphibole (amp), magnetite (mag), plagioclase (plag), quartz (qz), titanite (ttn) and uraninite (urn) .78

Fig. 3-2: Minor to trace element box (in ppm) and whisker plot of magnetite from this study plotted alongside representative IOAA data from Huang et al. (2019). 80

Fig. 3-3: Magnetite trace element plot normalized to bulk continental crust (BCC)

(Rudnick and Gao, 2003). Average trace element data for magnetite of high temperature hydrothermal deposits (high thtm), the Bushveld deposit (Fe-Ti-P type) and Banded Iron Formation deposit (Dare et al., 2014) and IOCG-type deposits (in green) (Huang et al., 2019) are also plotted. (a) Sample 18-CD-10 (n=1000) of the Gear deposit. (b) Sample 18-CD-16 ( $n=1749)$ of the Inda deposit, and (c) Average trace of both samples 81

Fig. 3-4: (a) BSE image and (b-h) LA-ICP-MS element maps of sample CD-18-10 containing coarse-grained magnetite in bands rimmed by magnetite and hematite, associated with amphibole and apatite.

Fig. 3-5: (a) BSE image and (b-h) LA-ICP-MS element maps of samples CD-18-16 containing fine-grained magnetite within a plagioclase and amphibole matrix. 83

Fig. 3-6: Ti vs. Ni/Cr of magnetite from the two samples analyzed by LA-ICP-MS, the dotted line denotes the magmatic and hydrothermal magnetite zones, modified from Dare et al (2014). 85 
Fig. 3-7: Magnetite discrimination plot (in wt \%) where the dotted line denotes the magmatic Fe $+\mathrm{Ti}, \mathrm{V}$ deposit field, modified from Dupuis and Beaudoin (2011).

Fig. 4-1: BSE images of (a) fine-grained amphibole and biotite matrix with fine-grained plagioclase that contains inclusions of muscovite, and fine-grained zircon and ilmenite from sample 17-CD-002 of the Gear deposit. (b) Fine-grained amphibole and plagioclase matrix with disseminated fine-grained uraninite, graphite and pyrite from sample 18CD-014a of the Kitts deposit. (c) Fine-grained amphibole and plagioclase matrix with disseminated fine-grained uraninite and veinlet uraninite with fine grained zircon intergrown from sample 18-CD-14a of the Kitts deposit. Abbreviations: amphibole (amp), biotite (bio), graph (graphite), ilmenite (ilm), muscovite (musc), plagioclase (plag), pyrite (py), urn (uraninite), zircon (zrc)

Fig. 4-2: BSE images of the zircons analyzed by SHRIMP, listed in Table 4-1, zircons (light

grey), uraninite (white)

Fig. 4-3: Concordia plot of zircon grains from sample 18-CD-14a .............................. 96 


\section{List of Appendices}

Appendix A: Major oxides (wt\%) EMPA data for uraninite analyses............................ 102

Appendix B: LA-ICP-MS average element data for magnetite analyses in ppm unless

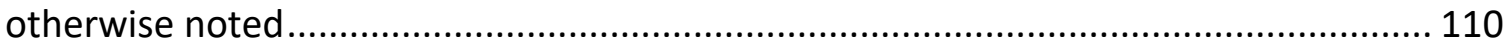




\subsection{Introduction}

The Central Mineral Belt (CMB) is a well-known uranium district located within central Labrador (Fig. 2-1) that hosts multiple $U \pm C u \pm M o \pm V \pm Z n \pm A u \pm A g \pm R e \pm R E E$ showings, prospects and undeveloped deposits in Neoarchean to Mesoproterozoic rocks (e.g., Gower et al., 1982; Ryan, 1984; Kerr, 1994; Sparkes et al. 2016; Sparkes 2017). Exploration in the area spiked in the 1960s and 1980s, with the most recent exploration and drilling occurring in 2003-2009 by Bayswater Uranium (Sparkes, 2017). The mineral occurrences and host rocks of the $\mathrm{CMB}$ are characterized by regional- to deposit-scale $\mathrm{Na}, \mathrm{Ca}-\mathrm{Fe}, \mathrm{K}$ and Fe alteration, as well as local hydrothermal breccia; all characteristic of iron oxide and alkali-calcic (IOAA) systems that host iron oxide-copper-gold (IOCG) deposits worldwide (Sparkes and Kerr, 2008; Corriveau et al., 2010, 2016; AcostaGóngora et al. 2018).

Since discovery of the Olympic Dam deposit in the 1970's and definition of the IOCG deposit type in the 1990's (Hitzman et al., 1992), these ore systems have been attractive targets for exploration. In addition to the potential for huge tonnages (e.g., Olympic Dam resources of $10,100 \mathrm{Mt}$ at $0.78 \% \mathrm{Cu}, 0.25 \mathrm{~kg} / \mathrm{t} \mathrm{U}_{3} \mathrm{O}_{8}, 0.33 \mathrm{~g} / \mathrm{t} \mathrm{Au}, 1 \mathrm{~g} / \mathrm{t} \mathrm{Ag}$; BHP, 2018), IOCG deposits also represent significant source of uranium, with Olympic Dam containing the world's largest recoverable source of uranium (OECD, 2018). Recent studies have proposed adoption of the term "iron oxide and alkali-calcic alteration" (IOAA) ore system (Porter, 2010; Corriveau et al., 2010, 2016) to encapsulate the regional-to local-scale alteration and deposit types characteristic of these systems. 
Development of IOAA systems requires huge volumes of hot, saline fluids that can interact with host rocks, generally through large scale crustal fault systems, repeated dyke emplacement indicative of continued heat/fluid input, and extensional regimes that allow for input of oxidizing fluids (Corriveau et al., 2016; Montreuil et al., 2015). The high temperature $\mathrm{Na}$ to $\mathrm{Ca}-\mathrm{Fe}$ alteration zones are early, pervasive and intense, and demarcate areas of interest that may form or host magnetite-apatite (iron oxide-apatite or IOA) deposits. Evolution to high temperature K-Fe (magnetite-Kfeldspar/biotite), skarn (clinopyroxene/garnet; e.g., Candelaria deposit) and then lower temperature $\mathrm{K}-\mathrm{Fe}\left(+\mathrm{H}_{2} \mathrm{O}-\mathrm{CO}_{2}\right)$ (sericite/K-feldspar-hematite-chlorite-carbonate) facies can produce significant polymetallic IOCG deposits, some of which may contain elevated concentrations of uranium. Textural pseudomorphing to texture-destructive recrystallization of protoliths is observed within IOAA systems, producing a variety of textures that make it difficult to identify alteration zones while mapping. However, using a 'facies' approach to understanding the evolution of alteration facies from regional- to deposit-scales makes the systems predictable (Corriveau et al., 2010a).

Iron oxide-apatite deposits (e.g., Kiruna) develop early in the IOAA system, at extremely high fluid temperatures $\left(>600^{\circ} \mathrm{C}\right)$ and deeper in the crust than IOCG deposits. Iron oxide-copper-gold deposits form at the transition from Ca-Fe to K-Fe facies, within magnetite- (magnetite-group IOCG; e.g., NICO deposit) and hematite-bearing (hematitegroups IOCG; e.g., Olympic Dam deposit) K-Fe alteration (Corriveau et al., 2016). Albitite-hosted uranium deposits (e.g., Michelin deposit), characterized by extensive albitite corridors which are controlled by regional-scale shear zones, allow for fluid flow 
form at depth in the thermal core of the IOAA system (Cuney, 2009; Cuney et al., 2012). Metal precipitation can occur when these albitite corridors are thrust upward into cooler or more distal alteration facies of the IOAA system (Montreuil et al., 2015; Corriveau et al., 2016; Potter et al., 2019).

IOCG and IOA deposits can both host large tonnages of metals, produced by large volumes of fluids penetrating the host rocks. The regional-scale IOAA systems frequently form structurally above calc-alkaline to shoshonitic, high temperature magma chambers that evolve to A-type magmas within a crust that is characterized by large-scale fault systems that promote heat and fluid flow. These systems can host a variety of economically significant deposits (IOCG, IOA, albitite-hosted uranium, certain skarns and certain intrusion-related deposits) rich in base, precious, specialty and/or actinide metals (Corriveau, 2007; Corriveau et al., 2010b, Montreuil et al., 2015). These seemingly distinct deposit types form systematically in a metasomatic-hydrothermal system from depth-to-surface across very high-temperature geothermal gradients within the upper crust (Fig. 1-1). Evolving chemical affinities of magma chambers is also observed as metasomatism proceeds and geodynamic conditions change regionally, interpreted by the temporal and spatial association of plutons with alteration of the Fab system (comprised of multiple Fe-Cu-U showings) in the Great Bear Magmatic zone (Montreuil et al., 2016). 


\begin{tabular}{|c|c|c|}
\hline Depth & Alteration Facies & Mineralization \\
\hline $\begin{array}{l}\text { Near surface } \\
\text { or distal } \\
\leq 350^{\circ} \mathrm{C}\end{array}$ & $\begin{array}{l}\text { 6. LT silicification (epithermal } \\
\text { K-Al alteration) }\end{array}$ & Epithermal style \\
\hline $\begin{array}{l}250^{\circ} \mathrm{C} \\
\mid \\
350^{\circ} \mathrm{C}\end{array}$ & $\begin{array}{l}\text { 5. LT K-Fe \& LT Ca-Fe (K- } \\
\text { feldspar/sericite-hematite- } \\
\text { carbonate-chlorite-epidote- } \\
\text { sulphides) }\end{array}$ & $\begin{array}{l}\text { Hem-group IOCG } \pm \mathrm{U} \\
\text { metasomatic } \mathrm{U}\end{array}$ \\
\hline $350^{\circ} \mathrm{C}$ & $\begin{array}{l}\text { 4. 'K-Felsite’ or K-skarns } \\
\text { (K-feldspar } \pm \text { clinopyroxene- } \\
\text { garnet-sulphides) }\end{array}$ & $\begin{array}{l}\text { Mag- to hem-group } \\
\text { IOCG, K-skarns, } \\
\text { metasomatic U }\end{array}$ \\
\hline $450^{\circ} \mathrm{C}$ & $\begin{array}{l}\text { 3. HT K-Fe (K-feldspar/biotite- } \\
\text { magnetite-sulphides) }\end{array}$ & $\begin{array}{l}\text { Mag-group IOCG } \\
(\mathrm{Cu}, \mathrm{Au}, \mathrm{Co}, \mathrm{Bi}, . . .)\end{array}$ \\
\hline $\begin{array}{l}450^{\circ} \mathrm{C} \\
\mid \\
800^{\circ} \mathrm{C}\end{array}$ & $\begin{array}{l}\text { 2. HT Ca-Fe ( } \pm \mathrm{Na}) \text { (amphibole- } \\
\text { magnetite } \pm \text { apatite) }\end{array}$ & $\begin{array}{l}(I O A) \pm \text { REE } \\
\text { Fe-skarns }\end{array}$ \\
\hline $\begin{array}{l}300-600^{\circ} \mathrm{C} \\
4-10 \mathrm{~km}\end{array}$ & 1. $\mathrm{Na}$ (albite - scapolite) & ground preparation \\
\hline
\end{tabular}

Fig. 1-1: Summary table of the alteration and mineralization of IOAA systems where depth is correlated to temperature (after Corriveau et al., 2010, 2016, 2018).

Abbreviations: High temperature (HT); low temperature (LT); hematite (hem); magnetite (mag).

Using petrography, novel quantitative element mapping of uraninite and

magnetite by laser-ablation inductively coupled plasma mass spectrometry (LA-ICP-MS), and zircon geochronology, this study examines the conditions of ore formation in the polymetallic ( $\mathrm{U}+/-\mathrm{Fe}, \mathrm{Cu}, \mathrm{Au}, \mathrm{REE})$ metasomatic ore deposits from the Kitts-Post Hill trend in the northeast $\mathrm{CMB}$. The quantitative element mapping permitted chemical characterization of mineral grains previously deemed too small ( $<20 \mu \mathrm{m}$ in diameter) for trace element analysis (Lawley et al, in prep.). Chondrite normalized patterns of both cores and altered rims of a selected uraninite grains were compared to the results of Martz et al. (2019) to better characterize the affect of fluids on REE mobilization in 
uraninite. Quantified magnetite LA-ICP-MS element maps are used to distinguish various mineralization events. Both U-Pb uraninite and zircon geochronology were used to constrain the timing of uranium mineralization of the Kitts-Post Hill belt. The results of this study are compared to other uranium deposits and IOAA systems (in particular the Great Bear magmatic zone, Canada's premier IOCG district) to validate that the characterization methods (alteration facies, geochemical characteristics, etc.) can be used to identify IOAA districts (Corriveau et al., 2010).

Uranium exploration and production at today's uranium price is less than appealing, but the forecast is bright, with countries such as China and India looking to significantly boost their nuclear power capacity by 2030 (IAEA, 2016, 2017). The possibility of renewed exploration interest in the $\mathrm{CMB}$ area could prove extremely beneficial for residents of the area, where job prospects are limited, and for the province through exploration expenditures and ultimately any mining royalties.

Our hypothesis for the $\mathrm{CMB}$ is that the various uranium-polymetallic showings may also be united under one single system, explained by the IOAA ore system model (Corriveau et al., 2010, 2016). This hypothesis will be tested in collaboration with other studies (Acosta-Góngora et al., 2019, submitted.) in an attempt to unite the Kitts-Post Hill belt and other deposits of the CMB. 
2.0 The evolution of metasomatic uranium ore systems in the Kitts-Post Hill belt of the

\title{
Central Mineral Belt, Labrador
}

\begin{abstract}
Uranium mineralization of the Kitts-Post Hill belt of the Central Mineral Belt is concentrated in the upper portion of the Post Hill Group, along a structurally complex shear zone located within the Makkovik Province of Labrador. Recent research in the $\mathrm{CMB}$ has highlighted regional-to deposit-scale $\mathrm{Na}, \mathrm{Ca}-\mathrm{Fe}, \mathrm{K}$ and Fe alteration, as well as local hydrothermal breccia; all characteristic of iron oxide and alkali-calcic alteration systems that host iron oxide-copper-gold (IOCG) and affiliated deposits.
\end{abstract}

In quantitative LA-ICP-MS maps, remobilization of uranium and LREE along grain boundaries and fractures support the varying degrees of alteration recorded in major and trace element chemistry. Primary uraninite contains elevated $\mathrm{Th}, \mathrm{Zr}$, and REE contents implying crystallization from high-temperature fluids capable of transporting high field strength elements. Altered grains are characterized by elevated $\mathrm{Zr}$, and low Th and REE contents that indicate potential remobilization in response to regional tectonicmagmatic events. In chondrite-normalized plots of uraninite, contrasting REE signatures also imply three populations along the corridor that formed at different temperatures and physico-chemical conditions. The inferred contrasting fluid sources, reflected in the major and trace element composition of uraninite reveal a complex fluid history, complicated by post-ore magmatism and metamorphism. 


\subsection{Introduction}

The Central Mineral Belt (CMB) is a well-known uranium district located within central Labrador (Fig. 2-1) that hosts multiple $U \pm C u \pm M o \pm V \pm Z n \pm A u \pm A g \pm R e \pm R E E$ showings, prospects and undeveloped deposits in Neoarchean to Mesoproterozoic rocks (e.g., Gower et al., 1982; Ryan, 1984; Kerr, 1994; Sparkes et al. 2016; Sparkes 2017). Exploration in the area spiked in the 1960s and 1980s, with the most recent exploration and drilling occurring in 2003-2009 by Bayswater Uranium (Sparkes, 2017). In the CMB, several types of uranium mineralization have been recognized, including albitite-hosted (e.g., Michelin deposit), hydrothermal veins and breccias (e.g., Moran Lake Upper C Zone) and sedimentary-hosted (e.g., Moran Lake Lower C Zone and Anna Lake deposits) (Sparkes, 2008; Sparkes et al., 2016; Sparkes, 2017; Sparkes et al, 2017). The mineral occurrences and host rocks of the $\mathrm{CMB}$ are characterized by regional- to deposit-scale $\mathrm{Na}, \mathrm{Ca}-\mathrm{Fe}, \mathrm{K}$ and Fe alteration, as well as local hydrothermal breccia; all characteristic of iron oxide and alkali-calcic (IOAA) systems worldwide (Sparkes and Kerr, 2008; Corriveau et al., 2010, 2016; Acosta-Góngora et al. 2018). Furthermore, Sparkes (2017) and Sparkes et al. (2017) proposed two uranium mineralization events in the eastern CMB: 2030-1880 Ma and 1860-1800 Ma that overlap with ages of mineralization proposed for the western uranium occurrences (1860-1660 Ma; Sparkes 2017) and orogenic events. The regional-scale alteration as well as the time constrained uranium mineralization are evidence that can possibly unite the currently disparate polymetallic deposits under the IOAA system. 
Since discovery of the Olympic Dam deposit in the 1970's and definition of the iron oxide-copper-gold (IOCG) deposit type in the 1990's (Hitzman et al., 1992), these deposits have been attractive targets for exploration. In addition to the potential for huge tonnages (e.g., Olympic Dam resources of $10,100 \mathrm{Mt}$ at $0.78 \% \mathrm{Cu}, 0.25 \mathrm{~kg} / \mathrm{t}$ U3O8, 0.33g/t Au, 1g/t Ag; BHP, 2018), IOCG deposits also represent significant source of uranium, with Olympic Dam containing the world's largest recoverable source of uranium (OECD, 2018). Recent studies have proposed adoption of the term "iron oxide and alkali-calcic alteration" (IOAA) ore system (Porter, 2010; Corriveau et al., 2010; Corriveau et al., 2016) to encapsulate the regional-to local-scale alteration and deposit types characteristic of these systems. These systems can host IOCG deposits senso stricto but also several affiliated deposit types including as albitite-hosted uranium. Although a genetic link between albitite-hosted uranium and IOCG deposits was recently proposed in the Great Bear magmatic zone (Montreuil et al., 2015; Potter et al., 2019), this linkage remains controversial, and albitite-hosted uranium was previously associated to carbonatite and/or alkaline magmatism emplacement (Wilde 2013). 


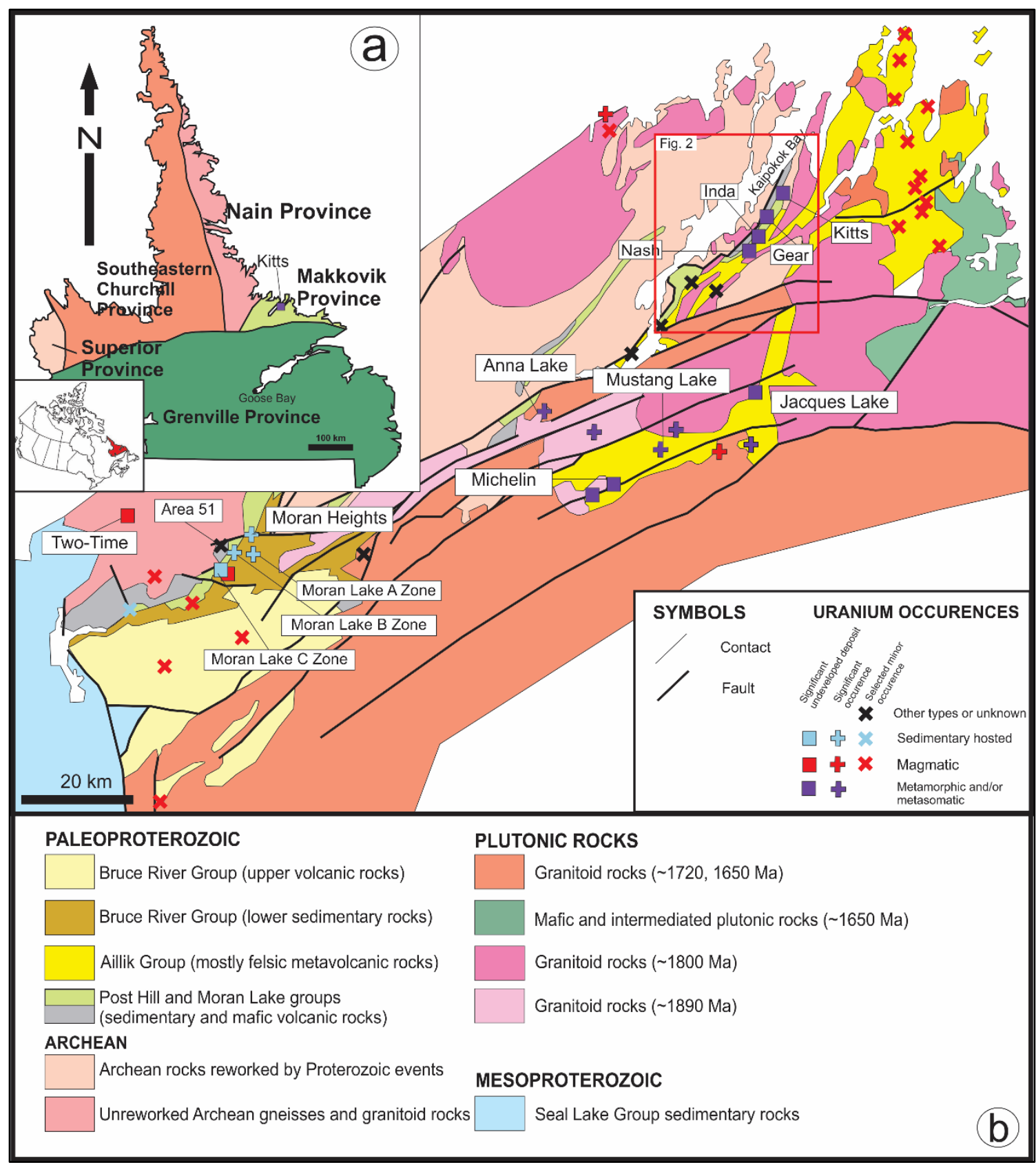

Fig. 2-1: (a) Location and geology of Labrador; (b) Geology of the Central Mineral Belt area, with locations of deposits and showings of uranium mineralization, modified from Kerr and Sparkes (2009). 
In this contribution we carried out detailed petrographic and novel major and trace quantitative element mapping of uraninite to examine the source(s) of uranium and conditions of ore formation in the polymetallic ( $\mathrm{U}+/-\mathrm{Fe}, \mathrm{Cu}, \mathrm{Au}, \mathrm{REE})$ metasomatic ore deposits from the Kitts-Post Hill trend (Inda, Gear and Nash deposits) located in the northeast $\mathrm{CMB}$. The geochemical signatures of uraninite from the studied CMB deposits are compared to those of other uranium deposits and IOAA systems elsewhere as means to establish potential genetic links between the CMB uranium district and IOAA systems. This hypothesis will be tested in collaboration with other studies (AcostaGóngora et al., 2019, submitted.) in an attempt to unite the Kitts-Post Hill belt with other deposits of the CMB.

\subsubsection{IOAA systems evolution}

The IOAA ore system model of Porter (2010), and updated by Corriveau et al. (2010, 2016), explains the development of IOCG deposits from their early, high temperature deep-seated $\mathrm{Na}$ alteration (formation of albitite) to shallower and lower temperature epithermal (e.g., silicification and argillic alteration) components. This alteration path describes the systematic emplacement of a series of metasomatic alteration types, allowing for the seemingly disparate showings over a large area to be explained by a single model.

Development of IOAA systems requires huge volumes of hot, saline fluids that interact with host rocks, generally through large scale crustal fault systems, and are driven by calc-alkaline to shoshonitic, high temperature magmatism, repeated dyke emplacement and extensional regimes that allow for input of oxidizing fluids (Corriveau 
et al., 2016; Montreuil et al., 2015). The high temperature Na to Ca-Fe alteration zones are early, pervasive and intense, and demarcate areas of interest or may form the host to magnetite-apatite (iron oxide-apatite or IOA) deposits. Evolution to high temperature K-Fe (magnetite-K-feldspar/biotite), skarn (clinopyroxene/garnet) and then lower temperature $\mathrm{K}-\mathrm{Fe}\left(+\mathrm{H}_{2} \mathrm{O}-\mathrm{CO}_{2}\right)$ (sericite/K-feldspar-hematite-chlorite-carbonate) facies can produce significant polymetallic IOCG deposits, some of which may contain elevated concentrations of uranium (Corriveau et al., 2010). Pseudomorphing to texturedestructive recrystallization of protoliths is observed within IOAA systems, resulting in alteration zones that are difficult to identify while mapping. However, using a "facies" approach, the evolution of alteration assemblages from regional- to deposit-scales is predictable (Corriveau et al., 2010a; 2016). Iron oxide-apatite deposits develop early in the IOAA system, at extremely high fluid temperatures $\left(>600^{\circ} \mathrm{C}\right)$ and deeper in the crust than magnetite or hematite-group IOCG deposits (Corriveau et al., 2016).

Albitite-hosted uranium deposits (also known as Na-metasomatic), are intepreted as a sub-type of the IOAA family. They are characterized by extensive albitite corridors which are controlled by regional-scale shear zones that allow for fluid flow (Cuney, 2009; Cuney et al., 2012), where uranium ore (uraninite-coeffinite), and associated gangue minerals (hematite, carbonates, biotite or phlogopite, quartz and Fe$\mathrm{Cu}$-Pb-sulfides) are syn-genetic to $\mathrm{Ca}-\mathrm{Mg}, \mathrm{K}$-and $\mathrm{K}$-Fe alteration types, yet post-date $\mathrm{Na}$ metasomatism (e.g., Porto da Silveira et al., 1991; Polito et al., 2009; Cuney et al., 2012; Kontonikas-Charos et al., 2014; Montreuil et al., 2015). As illustrated by the Southern Breccia albitite-hosted uranium occurrence and NICO magnetite-group IOCG deposit in 
the Great Bear magmatic zone in Canada, albitite-hosted uranium and IOCG deposits can occur together within a single IOAA system (Montreuil et al., 2015; Potter et al., 2019). Although albitite corridors are frequently barren in terms of metals, the Southern Breccia was thrusted upwards into cooler or more distal alteration facies of the system, allowing for metal precipitation (Montreuil et al., 2015; Corriveau et al., 2016; Potter et al., 2019).

Historically, uranium enrichment in IOCG systems have invoked the incursion of oxidized fluids to transport mobile $U^{6+}$ (cf. Hitzman and Valenta, 2005; Skirrow, 2010). However, recent experimental work has noted the presence of an $\mathrm{UCl}_{4}$ species that are stable under acidic and reduced conditions (Timofeev et al., 2018). Coupled with petrographic and uraninite trace element data, Potter et al. (accepted) propose that primary uranium precipitation in IOAA systems can occur during the reduced, high temperature K-Fe (magnetite) facies as the fluid temperatures decrease and $\mathrm{pH}$ changes. Subsequent dissolution-reprecipitation and remobilization of primary uraninite can occur during the transition to hematite-bearing K-Fe alteration, expanding the uranium potential in IOCG systems from magnetite-to hematite-bearing deposits (Potter et al., accepted).

Iron oxide-copper-gold and IOA deposits can both host large tonnages of metals, produced by large volumes of fluids penetrating the host rocks. The regional-scale IOAA systems frequently form structurally above calc-alkaline to shoshonitic, high temperature magma chambers that evolve to A-type magmas within a crust that is characterized by large-scale fault systems that promote heat and fluid flow. These 
systems can host a variety of economically significant deposits (IOCG, IOA, albititehosted uranium, certain skarns and certain intrusion-related deposits) rich in base, precious, specialty and/or actinide metals (Corriveau, 2007; Corriveau et al., 2010b, Montreuil et al., 2015). These seemingly distinct deposit types form in a systematic metasomatic-hydrothermal alteration system from depth-to-surface across very hightemperature geothermal gradients within the upper crust. Chemical affinities of the magma chambers evolve as metasomatism proceeds and geodynamic conditions change regionally, interpreted by the temporal and spatial association of plutons with alteration of the Fab system in the Great Bear magmatic zone (Montreuil et al., 2016).

\subsection{Regional Geology}

The CMB is located mostly within the Makkovik Province of Labrador, but also stretches into the Archean Nain Province, the Paleoproterozoic Churchill Province and the Mesoproterozoic Grenville Province. The Makkovik Province is separated from the Archean Nain Province to the northwest by the Kanairiktok shear zone, and is bound to the south by the Mesoproterozoic Grenville Province (Fig. 2-1). This area of Labrador has been the focus of many geological studies (e.g., Gandhi, 1978; Kerr et al., 1996; Hinchey, 2007; Sparkes, 2017).

This paper focuses on the Kaipokok and the Aillik domains of the Makkovik Province as defined by Gower and Ryan (1986), which are hosts to widespread uranium mineralization (Fig. 2-1b). The Aillik domain is separated from the Kaipokok domain by the Kaipokok Bay Structural Zone, a system of high-grade strain zones (Ketchum et al., 
1997). Archean basement rocks and overlying mafic volcanic and metavolcanic rocks comprise the majority of the Kaipokok and Aillik domains, with ages defined for a tonalite gneiss at $2878_{-16}^{+27} \mathrm{Ma}$ (Ketchum et al., 2001a) and a $2813_{-13}^{+16}$ Ma migmatitic granodiorite gneiss (Ketchum et al., 2002). The Kaipokok domain includes the ca. 2235 Ma Post Hill Group (Ketchum et al., 2002), a Paleoproterozoic supracrustal sequence metamorphosed to amphibolite facies. The Post Hill Group is dominated by siliciclastic and volcanic rocks (and geologic equivalent to the Moran Lake group in the southwest of the $\mathrm{CMB}$ ) that uncomformably overlie Archean basement and have been interpreted as deposited near the North Atlantic craton in a passive margin-foredeep succession (Ketchum et al., 2002; Hinchey, 2007).

The Makkovik Province is defined by the Makkovikian orogeny (ca. 1.85-1.75 Ga), an extension of the Ketilidian orogeny in southern Greenland (Gower \& Ryan, 1986). Rocks of the The Kaipokok domain were reworked during during the Makkovkian orogeny, when major zones of tectonic thrusting and thinning resulted in interleaving of the Archean basement and overlying Post Hill Group (Marten, 1977), development of a regional north-northeast tectonic fabric and shear zones, and greenschist to amphibolite facies metamorphism (Gower and Ryan, 1986; Ketchum et al., 1997).

The Aillik domain is dominated by the ca. 1860-1800 Ma Aillik Group, composed of metavolcanic and metasedimentary units that overly and are in tectonic contact with the Post Hill Group package (Marten, 1977; Gower et al., 1982; Kerr et al., 1996; Ketchum et al., 2002; Fig. 2-1b). Schärer et al. (1988) proposed that the Aillik Group formed during two distinct volcanic pulses, roughly coeval to the Makkovikian orogeny. 
Abundant calc-alkaline plutonic activity in the area, and extensional-setting mafic dykes which cut all units, indicate that the Aillik Group was deposited in a rifted-arc setting (Kerr et al., 1996; Culshaw et al., 2000).

Late east-west trending faults occur throughout the Makkovik Province, interepreted as forming during the Labradorian or Grenvillian orogeny. The Labradorian orogeny was first described by Nunn et al. (1984) as a ca. 1650 Ma deformationalmetamorphic event in the Grenville Province of south-west Labrador, distinct from the Trans-Hudson (2000-1800 Ma; Wardle et al., 1990) and later Grenville orogenies (12001000 Ma; Gower et al., 1992). Plutonic activity in the CMB has been subdivided into three categories based on timing of emplacement: (1) syntectonic Makkovikian rocks between 1840-1800 Ma; (2) post-tectonic Makkovikian rocks between 1800-1720 Ma; and (3) Labradorian plutonic rocks 1670-1630 Ma (Gower et al., 1992; Kerr et al., 1992). The Grenville Front marks the southern limit of the Makkovik province and northern limit of ca. 1.0 Ga Grenvillian deformation (Gower \& Ryan, 1986). No plutonism of Grenville age has been found in the Makkovik Province (Gower \& Ryan, 1986). Highangle reverse faults occur in the northern Grenville Province in Labrador, whereas moderate- to low-angle thrusts occur more towards the interior of the Grenville Province (Gower \& Ryan, 1986).

\subsection{Local Geology}

The area of study is comprised of two main geological units, the Post Hill (formerly known as the Lower Aillik Group; Evans, 1980) and Aillik (formerly known as 
the Upper Aillik Group; Evans, 1980) groups, which are described in detail below. The Post Hill Group is subdivided into four lithologic formations: (1) the metavolcanic Post Hill amphibolite; (2) the Metasedimentary Formation; (3) the Kitts pillow lava Formation; and (4) the Drunken Harbour supracrustal belt (Marten, 1977; Ketchum et al., 2002). Quartzite units from the Post Hill Group were deposited after $2235 \mathrm{Ma}$, based on Archean detrital zircon dates and the observation that the Kikkertavak dyke suite (ca. $2235 \mathrm{Ma}$ ) does not intrude these units (Cadman et al., 1993; Ketchum et al., 2002). Overlying the quartzite units are $2178 \pm 4$ Ma metavolcanic rocks and a ca. $2013 \mathrm{Ma}$ tubidite package from the Post Hill Group (Ketchum et al., 2002).

The ca. 1860 Ma Aillik Group unconformably overlies and is in tectonic contact with the the older Post Hill Group, and is subdivided into a lower unit consisting of various sedimentary units, dacite, rhyolite and mafic volcanic rocks, and an upper unit of felsic tuff, flow-banded rhyolite, sedimentary rocks and quartz feldspar porphyry (Gower and Ryan, 1987; Ketchum et al., 2002). Both units have greenschist to lower amphibolite facies metamorphic assemblages, are often recrystallized and locally silicified, but commonly also preserve some primary textures (Kerr et al., 1996; Ketchum et al., 2002).

A structurally complex shear zone separates the Post Hill Group in the west from the Aillik Group in the east, and is host to a large portion of the Post Hill Group uranium mineralization, including the Kitts, Gear, Inda and Nash deposits (Fig. 2-2) (Gandhi, 1978). Uranium mineralization at Kitts, Gear, Inda and Nash is concentrated in the upper portion of the Post Hill Group, close to the uncomformable contact with the Aillik 
Group, although in parts this contact is difficult to distinguish (Sparkes, 2017). Zircon U$\mathrm{Pb}$ geochronology from the Kitts metagabbro (interpreted to predate mineralization) yield an age of $2018+15 /-18 \mathrm{Ma}$, whereas zircon from a quartz-feldspar porphyry dyke cross-cutting the mineralization yielded an age of 1881.8 $\pm 3.4 \mathrm{Ma}$ (Sparkes et al., 2010). Although the dyke contains localized uraninite-filled fractures, these have been interpreted as remobillization of uranium from the host rock (Sparkes et al., 2010). The Aillik Group is mostly unmineralized, although Evans (1980) noted widespread alkali metasomatism, similar to that of the Michelin deposit. Tracing of units along strike between these deposits becomes difficult due to the intense deformation in this area. 


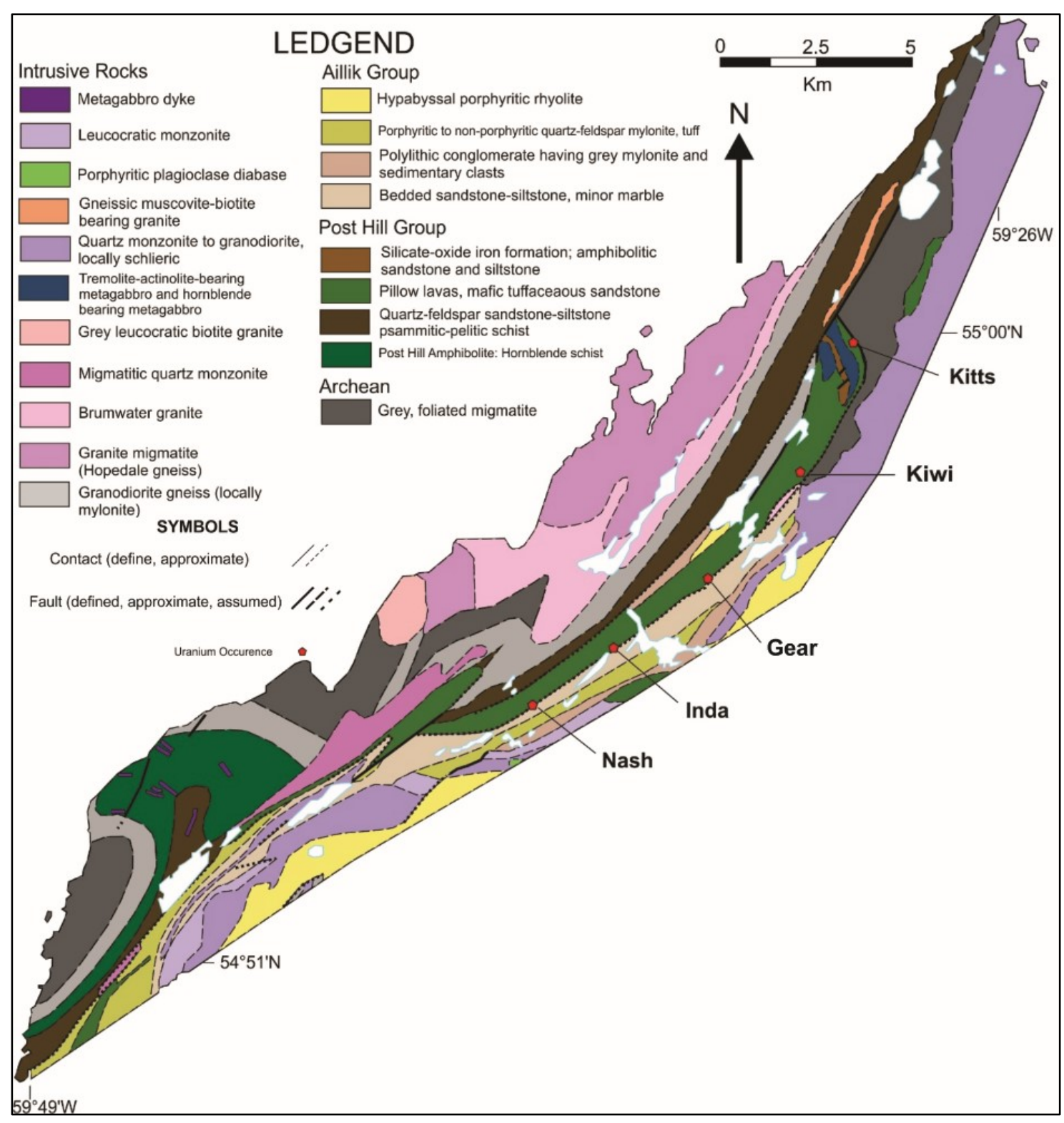

Fig. 2-2: Geology of the Post Hill group near the Kitts-Post Hill belt, modified from Sparkes (2017).

\subsubsection{Uranium genetic classification}

The genetic classification of uranium mineralization in the $\mathrm{CMB}$ has recently been summarized by Sparkes and Kerr (2008) and Sparkes (2017). Sparkes and Kerr (2008) divided the uranium mineralization into five categories: plutonic rocks-hosted, felsic volcanic-hosted, sedimentary-and metasedimentary hosted, hydrothermal 
breccias and iron oxide-rich breccias, and lastly hydrothermal veins. Sparkes (2017) condenses these five categories into just three; magmatic, sedimentary hosted, and lastly metamorphic-metasomatic. Magmatic uranium deposits generally occur in the Archean basement rocks (e.g., Kanairiktok prospect) or in pegmatitic intrusions (e.g., Dandy prospect), as well as in felsic volcanic rocks (e.g., Madsen and Melody Hill prospects) and mafic volcanic-hosted (e.g., Moran Lake Upper C Zone) iron oxide-rich breccias. Sedimentary-hosted uranium occurs mainly in the Moran Lake area and is characterized by "sandstone-type" (e.g., Moran Heights prospect and Moran Lower C Zone deposit) and "black shale-type" (e.g., Armstrong deposit) mineralization (Bruneton, 2014). Metamorphic-metasomatic uranium is most prominent in the central portion of the CMB (e.g., Michelin and Jacques Lake deposits), as well as the Kitts-Post Hill belt. All occurences seem to be structurally controlled, with fluids at least potentially related to metamorphic events (Evans, 1980; Sparkes, 2017).

\subsubsection{Deposits of the Kitts-Post Hill belt}

The uranium mineralization from the Kitts-Post Hill belt is hosted by the Aillik Group and the Post Hill Group. Mineralization is primarily developed within the Metasedimentary Formation argillite unit, locally interbedded with the Kitts pillow lava Formation and is interpreted as structurally constrained to foliation planes and shear zones (Sparkes, 2017).

Golder et al. (1977) reported non-NI-43-101 compliant indicated underground resource estimates for the Kitts deposit of $203880 \mathrm{lbs}$ of $\mathrm{U}_{3} \mathrm{O}_{8}$ at a grade of $0.73 \%$. Hertel et al. (2009) reported NI-43-101 compliant indicated underground resource 
estimates for Gear, Inda and Nash deposits of 532000,324000 and $214000 \mathrm{lbs}$ of $\mathrm{U}_{3} \mathrm{O}_{8}$, at grades of $0.73 \%, 0.080 \%, 0.070 \%$ and $0.060 \%$, respectively.

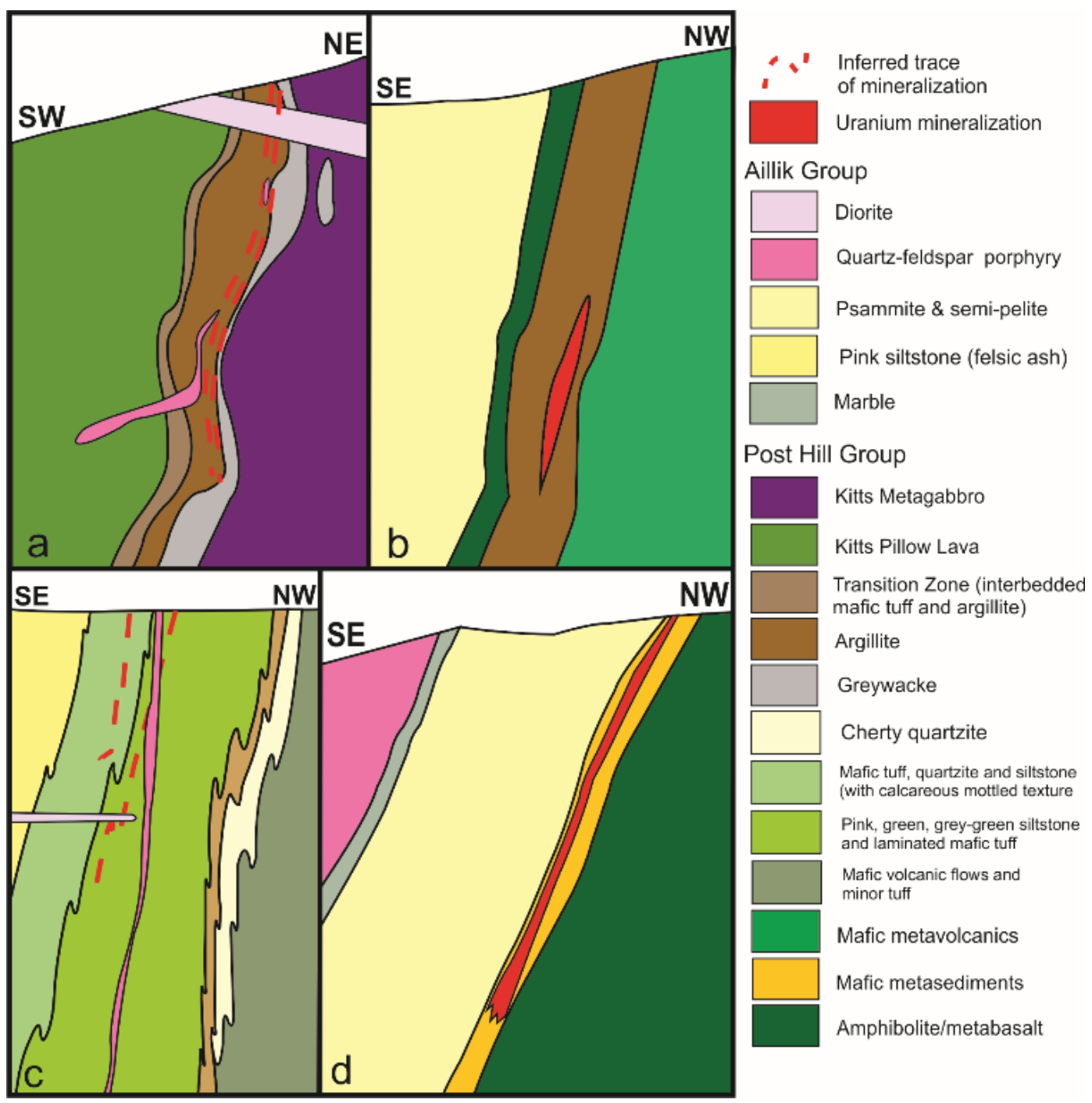

Fig. 2-3: Simplified cross section of the Kitts-Post Hill deposits; a) Kitts; b) Gear; c) Inda; and d) Nash. Modified from Sparkes (2017).

The geology of the Kitts deposit (Fig. 2-3a) is dominated by the Kitts Pillow lava, the Kitts Metagabbro and the argillite unit. The argillite unit consists of multiple beds that have been variably metamorphosed to greenschist-amphibolite facies. Two shear zones were observed in the Kitts deposit by Evans (1980): the northwest-trending Main 
Shear zone, that is host to uranium mineralization within the volcaniclastic units, and the north-northeast-trending Cross Shear zone, roughly parallel to regionally schistosity, but locally discordant to lithological contacts (Evans, 1980). Uranium mineralization is generally confined to the argillite unit, along shear zones proximal to the contact with the metagabbro, but minor mineralization also occurs within Kitts Pillow lava unit and quartz-feldspar porphyry (Sparkes, 2017). Mineralization seems to be structurally controlled by ductile deformation in the area, as uranium contents have greater than average values where folding is tight (Gandhi, 1978). Mineralization often forms microcrystalline veinlets and/or clots that are rimmed by chlorite, included within amphibole and/or intergrown with calcite, graphite and pyrrhotite.

Mineralization in the Gear (Fig. 2-3b), Inda (Fig. 2-3c) and Nash (Fig. 2-3d) deposits is primarily concentrated within the upper Post Hill Group, near the contact with the Aillik Group, within the argillite, meta-sedimentary and meta-volcanic rocks. The contact with the Aillik Group is at times strongly sheared. The footwall of the mineralized zones of the three deposits is largely composed of mafic metavolcanic rocks (Fig. 2-3). Mineralization at the Gear deposit is confined to the argillite unit where the host rocks are more quartz-rich than the other deposits. At the Inda deposit, uranium mineralization is associated with a zone of intercalated felsic and mafic volcanic rocks, bound by the Kitts Pillow lava unit. Mineralization at the Nash deposit is hosted within the Nakit Shear Zone (Marten, 1977), and uniquely is sometimes hosted within the ca. 1.8 Ga Aillik Group units. Evans (1980) suggested that the Aillik Group rocks to the west of the Gear, Inda and Nash deposits experienced alkali alteration similar to that seen at 
the Michelin deposit. Hydrothermal alteration is present throughout the Kitts-Post-Hill belt as veins of amphibole, pyroxene, biotite, magnetite and andradite. At the Gear deposit, a Cu-Zn relationship associated with the argillite unit was suggested by Evans (1980) as a possible source for base metal enrichment. Evans (1980) also suggested a relationship between vanadium and uranium mineralization.

\subsubsection{Timing of uranium mineralization}

The timing of the uranium mineralization of the Kitts-Post Hill belt is poorly constrained. Previous work by of Gandhi (1976b) reported highly variable pitchblende ${ }^{207} \mathrm{~Pb} /{ }^{206} \mathrm{~Pb}$ ages for Kitts, Gear and Inda of $1760 \mathrm{Ma}, 1990 \mathrm{Ma}$ and $1831 \mathrm{Ma}$ respectively. Wilton and Longerich (1993) in situ and bulk analyses of uraninite grains and separates via ICP-MS yielded two ${ }^{207} \mathrm{~Pb} /{ }^{206} \mathrm{~Pb}$ ages of $1777 \pm 9 \mathrm{Ma}$ and $1758 \pm 3 \mathrm{Ma}$ for the Kitts depsoit and an age of $1738 \pm 5$ Ma for the Inda deposit. Evans (1980) analyzed 24 pitchblende grains from the Kitts deposit by electron microprobe, which yielded a ${ }^{206} \mathrm{~Pb} /{ }^{238} \mathrm{U}$ age of $1785 \pm 115 \mathrm{Ma}$.

Recent geochronological studies by Sparkes et al. (2010) have shed light on the mineralization age of the Kitts deposit. Analysis of zircon from the pre-mineralization Kitts metagabbro yield an age of $2018+15 /-18 \mathrm{Ma}$, while zircon from the quartz-feldspar porphyry dyke that crosscuts mineralization yield an age of $1881.8 \pm 3.4 \mathrm{Ma}$. Although the dyke contains localized uraninite-filled fractures, these have been interpreted as remobillization of uranium from the host rock. Therefore the primary mineralization age of the Kitts deposit likely occurred between 2018 and $1881 \mathrm{Ma}$, which is older than the ages obtained by Gandhi (1976b), Evans (1980) and Wilton and Longerich (1993). 
Mineralization at the Nash deposit is hosted by ca. 1860 Ma felsic rocks of the Aillik Group, and thus, the mineralization at this deposit ocurred at $<1860 \mathrm{Ma}$, which is slightly younger than the age bracket suggested for the Kitts mineralization (Schärer et al., 1988; Sparkes et al., 2010).

\subsection{Methods}

\subsubsection{Rock collection and mineral identification}

Samples were collected from the Newfoundland and Labrador Geological Survey's core storage facility in St. John's, Newfoundland and from the Goose Bay Core Storage Library in Goose Bay, Labrador. Additional samples were collected from the Sunil S. Gandhi collection housed at the Geological Survey of Canada. Petrographic studies were complemented with scanning electron microscopy to identify the mineralogy and paragenetic relationships.

A Zeiss EVO 50 series scanning electron microscope (SEM) was used to describe the mineralogy of polished thin section samples at the Geological Survey of Canada in Ottawa, Ontario. This system includes a backscattered electron detector (BSE), EverhartThornley secondary electron detector (SE), a variable pressure secondary electron detector (VPSE) and a cathodoluminescence detector (CL). The Oxford energy dispersive spectrometry (EDS) system includes the X-MAX 150 silicon drift detector, with INCA Energy 450 software and AZtec Energy 3.1 microanalysis software. The SEM operating conditions were as follows: standard working distance of $8.5 \mathrm{~mm}$; voltage set at $20 \mathrm{kV}$, with a probe current of $400 \mathrm{pA}$ to $1 \mathrm{nA}$; and filament current set to $2^{\text {nd }}$ peak. Images of 
the samples were acquired using the back scattered electron (BSE) mode. The INCA mineral liberation analysis software was used to find and identify minerals based on chemical composition using EDS.

\subsubsection{Major and trace element geochemistry}

\subsubsection{Electron probe microanalyzer}

Targeted minerals were analyzed for elemental abundances using a JEOL 8230 electron probe microanalyzer at the University of Ottawa. Operating conditions were $20 \mathrm{kV}$ accelerating voltage and 10nA current, with 20 s on peak and 10 s off-peak counting times. A mixture of natural and synthetic pure metal, simple oxides and simple compounds were used as standards. Data were reduced with a ZAF matrix correction using JEOL software. Elements analyzed include: $\mathrm{Ca}, \mathrm{Ti}, \mathrm{Cr}, \mathrm{Si}, \mathrm{Fe}, \mathrm{V}, \mathrm{Al}, \mathrm{Mg}, \mathrm{Mn}, \mathrm{K}, \mathrm{Cl}, \mathrm{Zn}$, $\mathrm{F}, \mathrm{Na}, \mathrm{Sr}, \mathrm{Ba}, \mathrm{Ni}, \mathrm{Nb}, \mathrm{Ce}, \mathrm{La}, \mathrm{Nd}, \mathrm{Y}, \mathrm{Pr}, \mathrm{U}, \mathrm{Th}, \mathrm{Pb}, \mathrm{Sm}, \mathrm{Zr}$, and P.

\subsubsection{In-situ LA-ICP-MS element mapping}

Only four samples from the Kitts deposit were used for element mapping given the fine-grained nature $(<5 \mu \mathrm{m})$ of uraninite in the Kitts-Post Hill belt sample suite.

Element mapping of uraninite was carried out on selected areas of either thin or thick ( $200 \mu \mathrm{m})$ sections by laser ablation inductively coupled plasma mass spectrometry (LA-ICP-MS) at the Geological Survey of Canada, using a Photon Machines Analyte G2 193 excimer laser ablation system, with a Helex II ablation cell, coupled to an Agilent 7700x quadrupole ICP-MS. The mapping procedure closely follows the method of Lawley et al. (2015; in review). Element maps were constructed by rastering a focused 
laser beam across the sample surface to form a series of line scans. Laser conditions during the analytical sessions include: a fluence of $4.3-4.9 \mathrm{~J} / \mathrm{cm}^{2}$, a repetition rate of 30 $\mathrm{Hz}$, a spot size of $5 \mu \mathrm{m}$, and a scan speed of $5 \mu \mathrm{m} / \mathrm{s}$. Prior to each ablation pass, the sample surface was cleaned by rastering the laser across the sample at a rate of 2-3 pulses every $5 \mu \mathrm{m}$, followed by $50-60 \mathrm{~s}$ of washout. Each analysis began with $20 \mathrm{~s}$ of background measurement (gas blank). The ablation aerosol was transported out of the Helix II cell using $1 \mathrm{~L} / \mathrm{min}$ of helium gas, and was subsequently mixed with $\sim 1 \mathrm{~L} / \mathrm{min}$ of argon gas before entering the ICP-MS. The ICP-MS was tuned on NIST-612 to achieve $>9,000 \mathrm{cps} / \mathrm{ppm}$ on ${ }^{175} \mathrm{Lu}\left(50 \mu \mathrm{m}\right.$ spot, $\sim 7 \mathrm{~J} / \mathrm{cm}^{2}$ at $\left.10 \mathrm{~Hz}\right)$, while minimizing the production of oxides ( $<0.2 \%$ for ThO/Th) and maintaining a U/Th ratio of $\sim 1.0$. The total duty cycle time to measure all masses on the ICP-MS (in time-resolved analysis mode) was $250 \mathrm{~ms}$. Utilizing these settings, every $1 \mathrm{~s}$ of analysis or the equivalent of a 5 $\mu \mathrm{m}$ spot diameter, included four full scans of the mass spectrometer.

The calibration procedures of Jackson (2008) were followed during the mapping sessions. Standardization was achieved by calibrating the signals of unknowns against analyses of GSE-1G (for most major and trace elements), and internal reference materials pyrrhotite (sulphur calibration) and calcite (carbon calibration), and normalizing total element (or element oxide) concentrations to $100 \%$. Reference materials were analyzed every 20 unknowns to account for instrument drift during the mapping run. Line scans of secondary standards GSD-1G or NIST-160 were analyzed throughout the mapping sessions, and routinely yielded calculated concentrations within $5-10 \%$ of the accepted values for most elements. Reference values for GSE-1G, 
GSE-1G and NIST-610 are taken from the online geological and environmental reference materials database (GeoReM; Jochum et al., 2005). The software programs LAMTRACE and PixeLAte (Jackson, 2008) were used to calibrate the data and convert the line scans to elemental maps. Elements analyzed include: $\mathrm{Na}, \mathrm{Mg}, \mathrm{Al}, \mathrm{Si}, \mathrm{P}, \mathrm{S}, \mathrm{K}, \mathrm{Ca}, \mathrm{Ti}, \mathrm{V}, \mathrm{Cr}, \mathrm{Mn}$, $\mathrm{Fe}, \mathrm{Co}, \mathrm{Ni}, \mathrm{Cu}, \mathrm{Zn}, \mathrm{As}, \mathrm{Sr}, \mathrm{Y}, \mathrm{Zr}, \mathrm{Nb}, \mathrm{Mo}, \mathrm{Cs}, \mathrm{Ba}, \mathrm{La}, \mathrm{Ce}, \mathrm{Pr}, \mathrm{Nd}, \mathrm{Sm}, \mathrm{Eu}, \mathrm{Gd}, \mathrm{Tb}, \mathrm{Dy}, \mathrm{Ho}, \mathrm{Er}$, $\mathrm{Tm}, \mathrm{Yb}, \mathrm{Lu}, \mathrm{Hf}, \mathrm{Ta}, \mathrm{W}, \mathrm{TI},{ }^{206} \mathrm{~Pb},{ }^{207} \mathrm{~Pb},{ }^{208} \mathrm{~Pb}, \mathrm{Bi}, \mathrm{Th},{ }^{235} \mathrm{U}$, and ${ }^{238} \mathrm{U}$.

Chondrite normalized rare earth element patterns were produced from the LAICP-MS mapping data of individual spot analyses of uraninite, normalized to McDonough and Sun (1995). Using the methods outlined in Lawley et al. (in prep.), uraninite was filtered for alteration and mixed analyses (i.e., ablation of two or more minerals) by discarding spot analyses that had $<70 \mathrm{wt} \% \mathrm{UO}_{2},>1.5 \mathrm{wt} \% \mathrm{SiO}_{2}$ and $>1 \mathrm{wt} \% \mathrm{CaO}$.

\subsection{Results}

\subsubsection{Petrography}

The generalized paragenetic sequence for the sample suite is shown in Fig. 2-4. General sample information is given in Table 2-1 whereas Table 2-2 Fig. 2-5 and Fig. 2-6 present more detailed textures of selected samples.

Sodic alteration in the sample suite is pervasive and occurs as the primary alteration style in the form of a fine-grained albite matrix. Albite hosts REE mineralization (of an unidentifiable mineral) in some samples (Fig. 2-6c). Fine-grained Ca-Fe-amphibole and veins of fine-to coarse-grained Ca-Fe-amphibole locally crosscuts albite. Disseminated uraninite occurs as inclusions within amphibole, but is more often 
observed around the margins of amphibole grains/veins (Fig. 2-5f). Less commonly, the Ca-Fe-amphibole and uraninite also occur intergrown with magnetite (Fig. 2-5a).

Some skarn-like alteration is observed at the Gear deposit, and may be present in the Nash West deposit. The Ca-Fe skarn-like alteration occurs in the Gear deposit as pervasive pyroxene and andradite (Ca-Fe garnet), locally overprinting albite (Fig. 2-6a). Andradite occurs as veinlets rimmed by fine-grained plagioclase in a matrix of K-feldspar at the Nash West deposit, which may represent a skarn-like alteration phase (Fig. 2-6e).

Fine-grained K-feldspar or very fine-grained K-feldspar with myrmekitic-like albite inclusions occur syn-genetically with uraninite in veinlets cutting the $\mathrm{Na}$ alteration assemblage (Fig. 2-5e). Veinlets of fine-grained K-feldspar, calcite and minor amphibole are crosscut by veins of clinozoisite and magnetite (Fig. 2-6b). A veinlet of stilpnomelane was observed in sample GS-08-268 from the Kitts deposit, crosscutting albite (Fig. 2-6d). Stilpnomelane in spatial association with uraninite was observed in a sample from the Kitts deposit (Fig. 2-5c).

Varying uraninite textures occur throughout the sample suite including finegrained disseminations, fine-grained clusters, veinlets and fine-grained folded bands. All textures occur within the Ca-Fe alteration assemblage in spatial or genetic association with K-feldspar and at times overprinting magnetite (K-Fe alteration). Uraninite grains of Sample $18-C D-14 b$ are the coarsest-grained of the sample suite (50-100 $\mu \mathrm{m}$ diameter) and occur in "clusters" and in vein like structures (Fig. 2-5d). Uraninite grains of Sample GS-08-266 are on average $20 \mu \mathrm{m}$ in diameter and occur in "clusters" of grains, crosscut 
by iron oxide veins (Fig. 2-5b). Uraninite grains of Sample GS-08-267 are very fine-

grained (<20 um diameter) and occur in "clusters" and a vein-like structure (Fig. 2-5c).

Uraninite grains of Sample 17-CD-027 are very fine-grained ( $<20 \mu \mathrm{m}$ diameter) and

occur as disseminated in a vein-like structure (Fig. 2-5f).

Table 2-1: Location, drill hole and lithology information for the samples described

\begin{tabular}{cccccc}
\hline $\begin{array}{c}\text { Drill } \\
\text { Hole/Original } \\
\text { Sample number }\end{array}$ & $\begin{array}{c}\text { Sample } \\
\text { Number } \\
\text { (this study) }\end{array}$ & Deposit & From $(\mathbf{m})$ & To $(\mathbf{m})$ & Host \\
\hline \hline & $18-C D-10$ & Gear & Surface grab sample & Metavolcanic \\
\hline B-49 & $17-C D-16$ & Inda & Surface grab sample & Metavolcanic \\
\hline GS-08-266 & $17-C D-68$ & Kitts & Surface grab sample & Argillite \\
\hline GS-08-267 & $17-C D-69$ & Kitts & Surface grab sample & Argillite \\
\hline K-74-11 & $18-C D-14 b$ & Kitts & Surface grab sample & Argillite \\
\hline G-68-142 & $17-C D-09$ & Gear & 97.2 & 97.37 & Argillite \\
\hline NW-77-04 & $17-C D-18$ & Nash West & 21.05 & 21.25 & Metavolcanic \\
\hline G-68-135 & $17-C D-76$ & Gear & 15.41 & 15.52 & Metavolcanic \\
\hline B-49 & $17-C D-024$ & Kitts & 81.28 & 81.39 & Argillite \\
\hline GS-08-268 & $17-C D-70$ & Kitts & Surface grab sample & Argillite \\
\hline
\end{tabular}




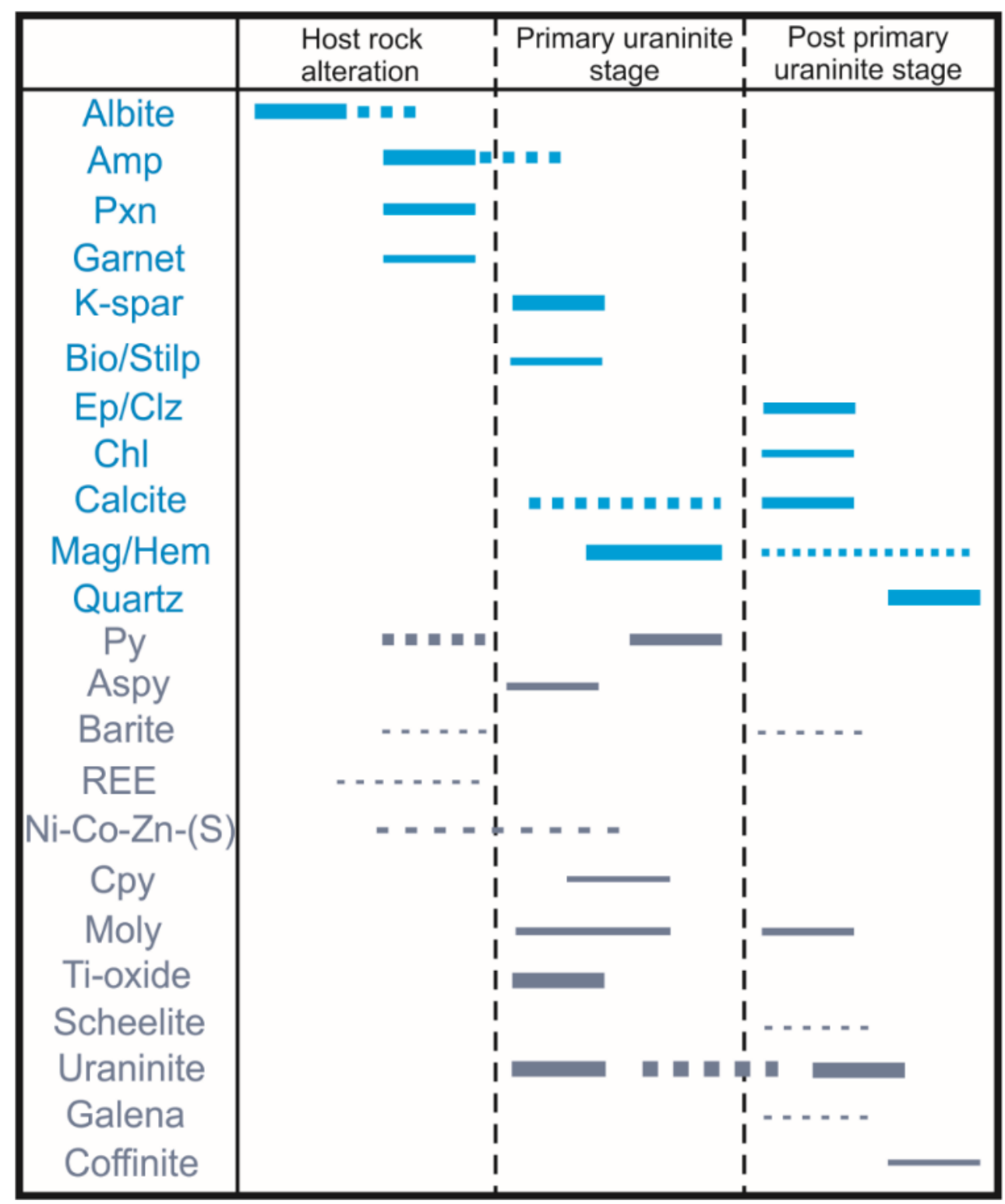

Fig. 2-4: Generalized paragenetic sequence of the deposits within the Kitts-Post Hill trend, weight of lines indicate relative abundance, dashed lines represent uncertainty in the sequence. Abbreviations: amphibole (amp), arsenopyrite (aspy), biotite (bio), chalcopyrite (cpy).chlorite (chl), clinozoisite (clz), epidote (ep), hematite (hem), Kfeldspar (K-spar), magnetite (mag), molybdenite (moly), pyrite (py), pyroxene (pxn) and, stilpnomelane (stilp). 
Table 2-2: Petrography of samples representative of alteration and mineralization within the sample suite. Abbreviations: amphibole (amp), andradite (adr), apatite (ap), arsenopyrite (aspy), biotite (bio), calcite (cal), chalcopyrite (cpy), clinozoisite (clz), epidote (ep), galena (gal), hematite (hem), ilmenite (ilm), K-feldspar (K-spar), magnetite (mag), molybdenite (moly), monazite (mnz), plagioclase (plag), pyrite (py), pyroxene (pxn), quartz (qz), titanite (ttn), and uraninite (urn).

\begin{tabular}{|c|c|c|c|c|}
\hline Deposit & Sample & Mineralogy & Textures & Grain sizes \\
\hline \multirow{4}{*}{ Kitts } & $18-C D-14 b$ & $\begin{array}{l}\text { amp, Na-plag, urn, py, } \\
\text { aspy, graphite }\end{array}$ & $\begin{array}{l}\text { amp + Na-plag matrix; urn clusters/veins; disseminated py, aspy, } \\
\text { graphite }\end{array}$ & $\begin{array}{l}\text { matrix }<500 \text { um; urn }<500 \text { um; py, } \\
\text { aspy, graphite }<300 \text { um }\end{array}$ \\
\hline & CD-17-67 & $\begin{array}{l}\text { amp, Na-plag, K-spar, } \\
\text { qz, urn, py, graphite }\end{array}$ & $\begin{array}{l}\text { amp + Na-plag + K-spar matrix; qz "pockets"; disseminated py, urn, } \\
\text { graphite }\end{array}$ & $\begin{array}{l}\text { silicates }<500 \text { um; urn, graphite }<50 \\
\text { um; py }<1 \mathrm{~mm}\end{array}$ \\
\hline & CD-17-66 & $\begin{array}{l}\text { amp, Na-plag, qz, K- } \\
\text { spar, ep, urn, py, ttn, } \\
\text { ilm, cpy, gal }\end{array}$ & $\begin{array}{l}\text { amp + Na-plag + qz + K-spar + ep matrix; disseminated py; clusters of } \\
\text { fine-grained urn, ttn, ilm; py intergrown with cpy (sometimes } \\
\text { oxidized); iron veins crosscut urn; secondary urn veins crosscut py }\end{array}$ & $\begin{array}{l}\text { silicates }<100 \text { um; urn, ttn, ilm }<75 \\
\text { um; py }<1 \mathrm{~mm}\end{array}$ \\
\hline & CD-17-027 & $\begin{array}{l}\text { amp, Na-plag, K-spar, } \\
\text { qz, urn, py, ttn, moly, } \\
\text { mnz }\end{array}$ & $\begin{array}{l}\text { plag + amp + K-spar + qz matrix; py veins oriented roughly same } \\
\text { direction, disseminated py and ttn, urn, moly, mnz occur in close } \\
\text { proximity to amp }\end{array}$ & $\begin{array}{l}\text { silicates }<100 \text { um; urn, ttn, moly } \\
<20 \text { um; py }<1 \mathrm{~mm} ; \mathrm{mnz}<100 \text { um }\end{array}$ \\
\hline Inda & $18-C D-16$ & $\begin{array}{l}\text { amp, Na-plag, mag, } \\
\text { hem, cal, ttn, urn }\end{array}$ & amp + Na-plag matrix; disseminated FeO, cal, ttn, urn & all grains $<100$ um \\
\hline \multirow{3}{*}{ Gear } & $18-C D-10$ & $\begin{array}{l}\text { mag, hem, Ca-amp, } \\
\text { plag, urn, qz, ap }\end{array}$ & $\begin{array}{l}\text { lamellae of FeO and amp + plag; disseminated urn and lamellae of } \\
\text { urn; minor qz in matrix, ap assc. with hem }\end{array}$ & $\begin{array}{l}\text { mag, hem, amp, plag, qz }<100 \text { um; } \\
\text { urn }<20 \text { um; ap }<50 \text { um }\end{array}$ \\
\hline & 17-CD-09 & $\begin{array}{l}\text { pxn, amp, adr, plag, } \\
\text { py, REE }\end{array}$ & $\begin{array}{l}\text { pxn + minor amp with wavey lamellae of adr in one half of section; } \\
\text { amp with minor pxn in other half; clusters of plag and disseminate } \\
\text { py; veins of plag seem crosscut by pxn; REE ore mineralization assc. } \\
\text { with plag in adr lamellae }\end{array}$ & $\begin{array}{l}\text { silicates }<1 \mathrm{~mm} \text {; disseminated py } \\
<1 \mathrm{~mm} \text { (single grain }>1 \mathrm{~cm} \text { ); REE }< \\
50 \mathrm{um}\end{array}$ \\
\hline & 17-CD-76 & $\begin{array}{l}\text { bio, amp, K-spar, cal, } \\
\text { plag, mag, ttn }\end{array}$ & $\begin{array}{l}\text { high altered; lamellae of bio + amp + minor K-spar + cal; matrix of K- } \\
\text { spar, bio, plag, amp, mag, ttn }\end{array}$ & $\begin{array}{l}\text { lamellae grains }<1 \mathrm{~mm} \text {; matrix } \mathrm{K}- \\
\text { spar, bio, plag }<100 \mathrm{um} \text {; matrix } \\
\text { amp, mag, ttn }<1 \mathrm{~mm}\end{array}$ \\
\hline Nash W & $17-C D-18$ & $\begin{array}{l}\text { amp, K-spar, cal, amp, } \\
\text { plag, clz, mag }\end{array}$ & $\begin{array}{l}\text { alternating layers of amp, K-spar, cal; amp, plag, minor clz and K- } \\
\text { spar; clz and mag }\end{array}$ & $\begin{array}{l}\text { all grains }<1 \mathrm{~mm} \text {; mag and clz layer } \\
<2 \mathrm{~mm}\end{array}$ \\
\hline
\end{tabular}




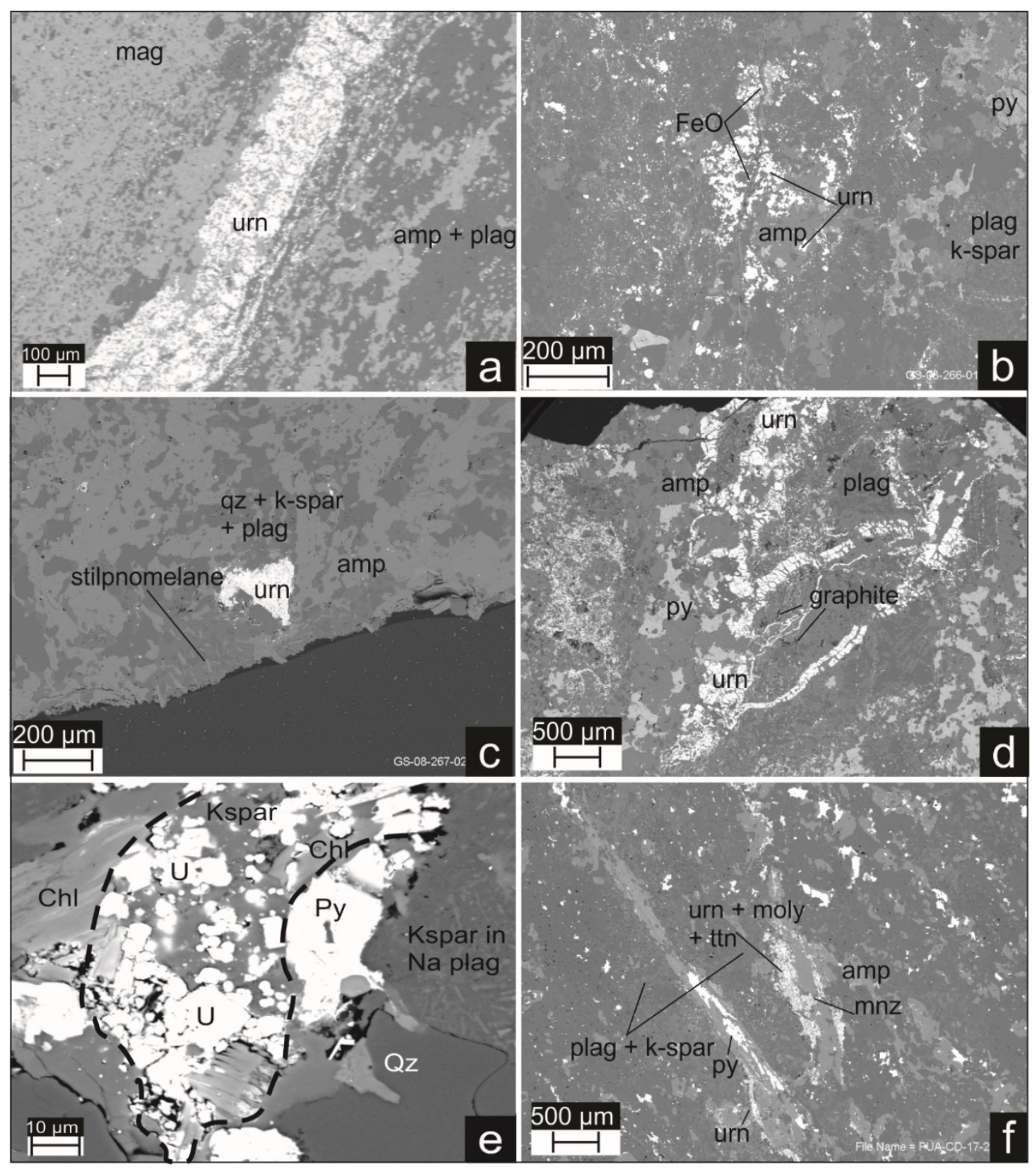

Fig. 2-5: Backscatter electron (BSE) images of (a) fine-grained uraninite in veinlet cutting albite, amphibole and magnetite; sample 18-CD-10. (b) Fine-grained uraninite in amphibole, plagioclase and K-feldspar crosscut by late iron oxide veinlet; sample GS-08266. (c) Uraninite in amphibole, plagioclase, quartz, K-feldspar and stilpnomelane; sample GS-08-267, (d) Coarse-grained uraninite veinlet crosscutting plagioclase and amphibole; sample 18-CD-14b. (e) Fine-grained uraninite in matrix of K-feldspar and chlorite; sample 17-CD-024. (f) Fine-grained amphibole veinlet crosscutting plagioclase, rimmed by fine-grained uraninite, molybdenite, titanite and monzonite; sample CD-17027. Mineral abbreviations defined in Table 2-2. 


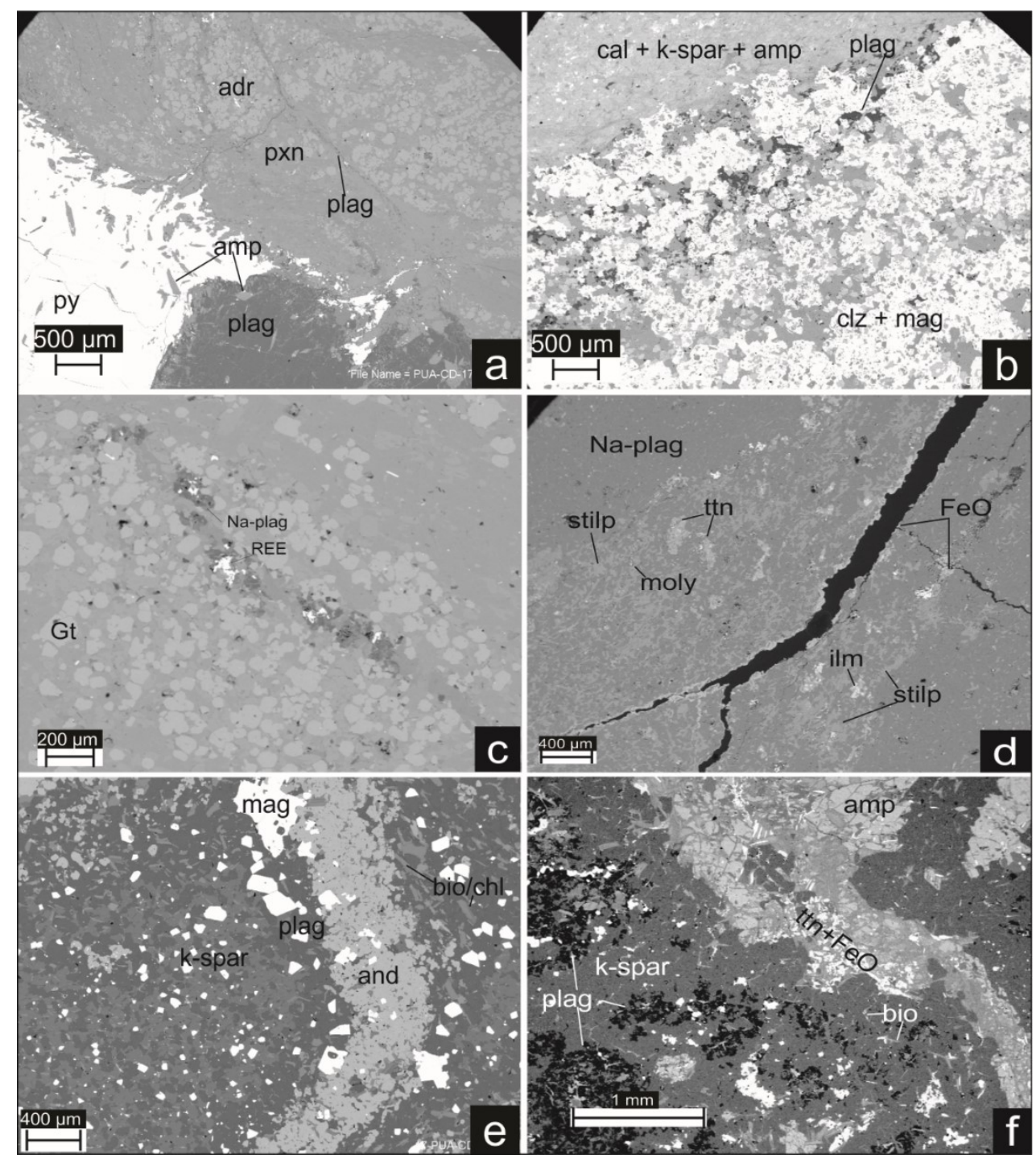

Fig. 2-6: BSE images of (a) coarse-grained pyrite with inclusions of amphibole in matrix of plagioclase, juxtaposed against a matrix of pyroxene and andradite, which is being cross-cut by veinlet of fine-grained plagioclase; Sample 17-CD-09. (b) Clinozoisite and magnetite veinlet crosscutting matrix of plagioclase, amphibole, K-feldspar and calcite; Sample 17-CD-17. (c) Amphibole and garnet matrix hosting a plagioclase veinlet, that is host to fine-grained REE mineralization; Sample 17-CD-09. (d) Veinlet of fine-grained stilpnomelane with minor molybdenite, titanite and ilmenite crosscutting plagioclase matrix; Sample GS-08-268. (e) Fine-grained andradite veinlet crosscutting plagioclase, biotite/chlorite and K-feldspar, overprinted by magnetite; Sample 17-CD-10. (f) Coarsegrained amphibole-titanite-iron-oxide veinlet crosscutting plagioclase, K-feldspar and biotite matrix; Sample 17-CD-76. Mineral abbreviations defined in Table 2-2. 


\subsubsection{EMPA Data}

Data from electron probe microanalyzer for the various samples are presented below. Table 2-3 and Table 2-4 show the compositional analyses for silicates and uraninite, respectively.

Chemical U-Pb ages for uraninite grains analyzed by EMPA were generated using the Bowles (2015) method and revealed three age populations that coincide with the three REE patterns revealed by LA-ICP-MS (Fig. 2-14). The youngest population centers on the 1400-1420 Ma bracket, defined by sample 17-CD-027 and 17-CD-024. The largest population is centred on the 1620-1640 Ma age bracket, defined by sample GS-08-266 and GS-08-267. The oldest population is centred on the 1800-1820 Ma age bracket, defined by the samples 18-CD-14a and $b$. There are two outliers, one sample spot gave a very young age of $<1200 \mathrm{Ma}$ and two sample spots gave very old ages of $>2000 \mathrm{Ma}$. 
Table 2-3: Silicate EMPA data in wt \% (* denotes average composition, DL denotes detection limit)

\begin{tabular}{|c|c|c|c|c|c|c|c|c|c|c|}
\hline & \multicolumn{10}{|c|}{ AMP } \\
\hline & $\begin{array}{c}\text { *17-CD- } \\
027 \\
\end{array}$ & $\sigma$ & $\begin{array}{c}* 18- \\
\text { CD-10 }\end{array}$ & $\sigma$ & $\begin{array}{l}\text { *GS-08- } \\
267-01 \\
\end{array}$ & $\sigma$ & $\begin{array}{l}\text { GS-08- } \\
267-03 \\
\end{array}$ & $\mathrm{DL}$ & $\begin{array}{l}\text { *GS-08- } \\
266-01 b\end{array}$ & $\sigma$ \\
\hline $\mathrm{CaO}$ & 11.67 & 0.03 & 10.85 & 0.06 & 11.72 & 0.07 & 11.66 & 0.02 & 11.43 & 0.06 \\
\hline $\mathrm{TiO}_{2}$ & 0.33 & 0.01 & 0.32 & 0.02 & 0.82 & 0.03 & 0.81 & 0.02 & 0.62 & 0.03 \\
\hline $\mathrm{Cr}_{2} \mathrm{O}_{3}$ & 0.21 & 0.01 & - & 0.01 & - & & - & 0.02 & 0.09 & 0.01 \\
\hline $\mathrm{SiO}_{2}$ & 49.75 & 0.27 & 39.50 & 0.35 & 43.13 & 0.44 & 42.59 & 0.03 & 45.92 & 0.54 \\
\hline $\mathrm{FeO}$ & 13.21 & 0.24 & 19.85 & 0.39 & 20.88 & 0.10 & 20.63 & 0.04 & 18.26 & 0.09 \\
\hline $\mathrm{V}_{2} \mathrm{O}_{3}$ & 0.32 & 0.09 & 0.94 & 0.04 & 0.08 & 0.03 & 0.16 & 0.04 & 0.12 & 0.02 \\
\hline $\mathrm{Al}_{2} \mathrm{O}_{3}$ & 5.82 & 0.01 & 12.94 & 0.19 & 12.45 & 0.31 & 12.17 & 0.02 & 9.36 & 0.17 \\
\hline $\mathrm{MgO}$ & 14.36 & 0.07 & 8.23 & 0.15 & 6.62 & 0.25 & 6.78 & 0.02 & 9.40 & 0.24 \\
\hline $\mathrm{MnO}$ & 0.49 & 0.02 & 0.84 & 0.01 & 0.31 & 0.03 & 0.36 & 0.03 & 0.49 & 0.03 \\
\hline $\mathrm{K}_{2} \mathrm{O}$ & 0.14 & 0.02 & 0.49 & 0.03 & 0.90 & 0.02 & 0.90 & 0.02 & 0.38 & 0.03 \\
\hline $\mathrm{Cl}$ & - & & - & - & 0.05 & 0.01 & 0.05 & 0.01 & 0.06 & 0.01 \\
\hline $\mathrm{ZnO}$ & - & & - & 0.05 & 0.06 & 0.05 & 0.06 & 0.10 & 0.08 & 0.02 \\
\hline $\mathrm{F}$ & 0.12 & 0.01 & - & 0.12 & 0.18 & 0.14 & 0.23 & 0.21 & 0.15 & 0.08 \\
\hline $\mathrm{Na}_{2} \mathrm{O}$ & 0.69 & 0.03 & 2.80 & 0.06 & 1.03 & 0.05 & 1.07 & 0.03 & 0.85 & 0.05 \\
\hline $\mathrm{SrO}$ & 0.08 & 0.02 & 0.11 & 0.02 & 0.07 & 0.02 & 0.09 & 0.04 & 0.11 & 0.01 \\
\hline $\mathrm{BaO}$ & - & & - & 0.02 & - & & - & 0.04 & - & \\
\hline $\mathrm{NiO}$ & - & & - & - & - & & - & 0.04 & - & \\
\hline $\mathrm{Nb}_{2} \mathrm{O}_{5}$ & - & & - & 0.05 & - & & - & 0.11 & - & \\
\hline TOTAL & 97.19 & & 96.87 & & 98.30 & & 97.56 & & 97.32 & \\
\hline
\end{tabular}

\begin{tabular}{|c|c|c|c|c|}
\hline & $\mathrm{CHL}$ & PLAG & $\begin{array}{c}\mathrm{K}- \\
\text { SPAR }\end{array}$ & PXN \\
\hline & $\begin{array}{c}17-\mathrm{CD}- \\
024\end{array}$ & $\begin{array}{c}17- \\
\text { CD- }\end{array}$ & $\begin{array}{c}17-\mathrm{CD}- \\
024\end{array}$ & $17-\mathrm{CD}-008$ \\
& & 024 & & \\
\hline \hline $\mathrm{CaO}$ & 1.82 & 2.15 & 0.15 & 22.99 \\
$\mathrm{TiO}_{2}$ & 1.04 & - & - & - \\
$\mathrm{Cr}_{2} \mathrm{O}_{3}$ & 0.24 & - & - & - \\
$\mathrm{SiO}_{2}$ & 27.33 & 63.04 & 64.19 & 51.07 \\
$\mathrm{FeO}$ & 24.24 & 0.65 & 0.67 & 18.35 \\
$\mathrm{~V}_{2} \mathrm{O}_{3}$ & 0.14 & - & - & - \\
$\mathrm{Al}_{2} \mathrm{O}_{3}$ & 16.88 & 22.33 & 18.49 & 0.31 \\
$\mathrm{MgO}$ & 6.92 & 0.10 & - & 6.69 \\
$\mathrm{MnO}$ & 1.65 & - & - & 1.16 \\
$\mathrm{~K}_{2} \mathrm{O}$ & 0.06 & 1.24 & 15.10 & - \\
$\mathrm{Cl}$ & 0.16 & - & - & - \\
$\mathrm{ZnO}$ & 0.25 & - & 0.05 & 0.09 \\
$\mathrm{~F}$ & 0.07 & 0.10 & - & 0.13 \\
$\mathrm{Na}{ }_{2} \mathrm{O}$ & 0.12 & 10.05 & 0.16 & 0.25 \\
$\mathrm{SrO}$ & - & 0.18 & - & 0.10 \\
$\mathrm{BaO}$ & - & - & 0.33 & - \\
\hline $\mathrm{TOTAL}$ & 80.98 & 99.91 & 99.20 & 101.26 \\
\hline
\end{tabular}


Table 2-4: Average uraninite compositions in wt\% from each sample area

\begin{tabular}{|c|c|c|c|c|c|c|c|c|c|c|c|c|c|c|}
\hline & \multirow{2}{*}{\multicolumn{2}{|c|}{$\begin{array}{c}17-C D-025 \\
\sigma \\
\end{array}$}} & \multirow{2}{*}{\multicolumn{2}{|c|}{$\begin{array}{r}17-C D-027 \\
\sigma \\
\end{array}$}} & \multirow{2}{*}{\multicolumn{2}{|c|}{$\begin{array}{r}17-C D-024 \\
\sigma \\
\end{array}$}} & \multicolumn{8}{|c|}{ GS-08-266 } \\
\hline & & & & & & & $1 a$ & $\sigma$ & $1 b$ & $\sigma$ & $1 c$ & $\sigma$ & 2 & $\sigma$ \\
\hline $\mathrm{SiO}_{2}$ & 0.33 & 0.25 & 0.09 & 0.27 & - & 0.04 & 0.1 & 0.07 & 0.15 & 0.07 & 0.17 & 0.10 & 0.15 & 0.13 \\
\hline $\mathrm{UO}_{2}$ & 73.37 & 2.44 & 73.86 & 1.18 & 73.66 & 1.13 & 77.07 & 0.87 & 76.8 & 0.87 & 77.16 & 0.98 & 76.63 & 1.01 \\
\hline $\mathrm{PbO}$ & 20.28 & 0.60 & 20.48 & 0.50 & 20.67 & 0.53 & 20.35 & 0.59 & 20 & 0.59 & 20.13 & 0.78 & 20.44 & 0.90 \\
\hline $\mathrm{CaO}$ & 0.24 & 0.15 & 0.23 & 0.13 & 0.08 & 0.04 & 0.25 & 0.08 & 0.31 & 0.08 & 0.3 & 0.16 & 0.24 & 0.08 \\
\hline $\mathrm{La}_{2} \mathrm{O}_{3}$ & - & 0.06 & 0.08 & 0.11 & 0.16 & 0.15 & 0.07 & 0.08 & 0.07 & 0.08 & - & 0.07 & 0.08 & 0.12 \\
\hline $\mathrm{Ce}_{2} \mathrm{O}_{3}$ & 0.18 & 0.10 & 0.09 & 0.09 & 0.14 & 0.06 & 0.1 & 0.09 & 0.1 & 0.09 & 0.09 & 0.10 & 0.13 & 0.11 \\
\hline $\mathrm{Nd}_{2} \mathrm{O}_{3}$ & 0.18 & 0.17 & 0.17 & 0.10 & 0.17 & 0.12 & 0.18 & 0.10 & 0.17 & 0.10 & 0.16 & 0.10 & 0.17 & 0.10 \\
\hline $\mathrm{Sm}_{2} \mathrm{O}_{3}$ & 0.11 & 0.06 & 0.13 & 0.09 & 0.1 & 0.07 & 0.05 & 0.05 & - & 0.05 & 0.05 & 0.05 & 0.05 & 0.06 \\
\hline $\mathrm{FeO}$ & 0.9 & 0.46 & 0.31 & 0.18 & 0.54 & 0.21 & 0.19 & 0.14 & 0.2 & 0.14 & 0.16 & 0.16 & 0.23 & 0.18 \\
\hline $\mathrm{ThO}_{2}$ & 0.85 & 0.20 & 0.06 & 0.05 & 2.24 & 0.18 & 0.05 & 0.05 & - & 0.05 & 0.06 & 0.06 & 0.09 & 0.07 \\
\hline $\mathrm{P}_{2} \mathrm{O}_{5}$ & - & 0.00 & - & 0.00 & - & 0.00 & - & 0.02 & - & 0.02 & - & 0.02 & - & 0.01 \\
\hline $\mathrm{Y}_{2} \mathrm{O}_{3}$ & 0.74 & 0.12 & 1.78 & 0.55 & 1.23 & 0.12 & 0.2 & 0.06 & 0.18 & 0.06 & 0.17 & 0.07 & 0.27 & 0.08 \\
\hline $\mathrm{ZrO}_{2}$ & 0.66 & 0.85 & 0.15 & 0.13 & - & 0.03 & 0.05 & 0.07 & - & 0.07 & - & 0.05 & 0.27 & 0.94 \\
\hline \multirow[t]{3}{*}{ Total } & 97.88 & 1.61 & 95.92 & 0.54 & 99.05 & 1.57 & 98.62 & 1.09 & 97.97 & 1.09 & 98.43 & 1.12 & 98.68 & 1.32 \\
\hline & \multicolumn{4}{|c|}{ GS-08-267 } & \multicolumn{6}{|c|}{ 18-CD-14a } & \multicolumn{2}{|c|}{$18-C D-14 b$} & & \\
\hline & 1 & $\sigma$ & 3 & $\sigma$ & 1 & $\sigma$ & 2 & $\sigma$ & 3 & $\sigma$ & 1 & $\sigma$ & & \\
\hline $\mathrm{SiO}_{2}$ & 0.11 & 0.06 & 0.11 & 0.04 & 0.18 & 0.13 & 0.2 & 0.24 & 0.1 & 0.03 & 0.32 & 0.21 & & \\
\hline $\mathrm{UO}_{2}$ & 76.78 & 1.83 & 75.17 & 0.73 & 78.23 & 2.06 & 77.82 & 0.69 & 77.02 & 1.12 & 77.84 & 1.06 & & \\
\hline $\mathrm{PbO}$ & 20.42 & 1.86 & 19.83 & 0.58 & 21.45 & 0.75 & 21.54 & 0.41 & 21.18 & 0.37 & 21.37 & 0.30 & & \\
\hline $\mathrm{CaO}$ & 0.33 & 0.21 & 0.26 & 0.09 & 0.39 & 0.17 & 0.31 & 0.06 & 0.32 & 0.04 & 0.48 & 0.08 & & \\
\hline $\mathrm{La}_{2} \mathrm{O}_{3}$ & 0.06 & 0.09 & - & 0.05 & 0.1 & 0.07 & 0.08 & 0.13 & 0.07 & 0.11 & 0.06 & 0.06 & & \\
\hline $\mathrm{Ce}_{2} \mathrm{O}_{3}$ & 0.11 & 0.10 & 0.08 & 0.06 & 0.12 & 0.09 & 0.15 & 0.07 & 0.13 & 0.09 & 0.05 & 0.05 & & \\
\hline $\mathrm{Nd}_{2} \mathrm{O}_{3}$ & 0.18 & 0.09 & 0.19 & 0.09 & 0.24 & 0.13 & 0.31 & 0.07 & 0.27 & 0.08 & 0.16 & 0.10 & & \\
\hline $\mathrm{Sm}_{2} \mathrm{O}_{3}$ & 0.05 & 0.05 & - & 0.06 & - & 0.03 & 0.04 & 0.05 & - & 0.02 & 0.04 & 0.03 & & \\
\hline $\mathrm{FeO}$ & 0.45 & 0.18 & 0.07 & 0.03 & 0.15 & 0.20 & - & 0.02 & 0.09 & 0.07 & 0.08 & 0.05 & & \\
\hline $\mathrm{ThO}_{2}$ & 0.05 & 0.05 & - & 0.02 & 0.05 & 0.05 & 0.11 & 0.08 & - & 0.04 & 0.06 & 0.06 & & \\
\hline $\mathrm{P}_{2} \mathrm{O}_{5}$ & 0.01 & 0.02 & - & 0.03 & - & 0.02 & - & 0.03 & 0.01 & 0.02 & - & 0.00 & & \\
\hline $\mathrm{Y}_{2} \mathrm{O}_{3}$ & 0.18 & 0.11 & 0.32 & 0.07 & 0.11 & 0.03 & 0.12 & 0.04 & 0.11 & 0.04 & 0.1 & 0.05 & & \\
\hline $\mathrm{ZrO}_{2}$ & - & 0.04 & 0.05 & 0.04 & 0.08 & 0.16 & - & 0.03 & - & 0.03 & - & 0.04 & & \\
\hline Total & 98.72 & 1.51 & 96.12 & 0.83 & 101.01 & 2.94 & 100.66 & 0.87 & 99.3 & 0.88 & 100.37 & 1.26 & & \\
\hline
\end{tabular}




\subsubsection{LA-ICP-MS data}

Laser ablation inductively coupled plasma mass spectrometry analyses of uraninite from the Kitts deposit revealed three distinct uraninite compositions, visible in chondrite normalized REE plots (Fig. 2-7). Three different groups were defined on the basis of their REE patterns and light to heavy REE ratios (LREE/HREE) in the Kitts samples. Group 1 uraninite are characterized by sample $18-C D-14 b$ which has a relatively flat-bell shape pattern and a median LREE/HREE value of 0.99. Group 2 uraninite are characterized by sample GS-08-266 which has a pseudo-bell shape pattern, a positive Eu anomaly and a median LREE/HREE value of 1.08. Group 3 uraninite are characterized by samples GS-08-267 and 17-CD-027, which have a lop-sided bell shape pattern, negative Eu anomaly and a median LREE/HREE value of 0.58. Representative LA-ICP-MS trace element data of uraninite are given in Table 2-5.

Overall REE abundances of Group 1 are the lowest of all three, with a median value for the sum of REEs of 0.12 wt\%. The U/Th ratio varies from 1054 to 11 332, with a median value of 2889 , corresponding with the highest values of the dataset (Table 2-5). Group 1 uraninite are variably altered, as revealed by the change in $U$ contents across the grains, as well as a slight increase in $\mathrm{K}$ (Fig. 8b; up to $0.65 \mathrm{wt} \%$ ) and a decrease of Th from 1680 ppm to 87 ppm (Fig. 2-8f). Slight $\mathrm{UO}_{2}$ and La enrichment of about 0.5 wt\% and $2 \mathrm{ppm}$, respectively, occur along grain boundaries (Fig. 2-8b,e). An enrichment in $\mathrm{Zr}$ in the form of clusters or inclusions within the uraninite grains is visible in Fig. 2-8d. 


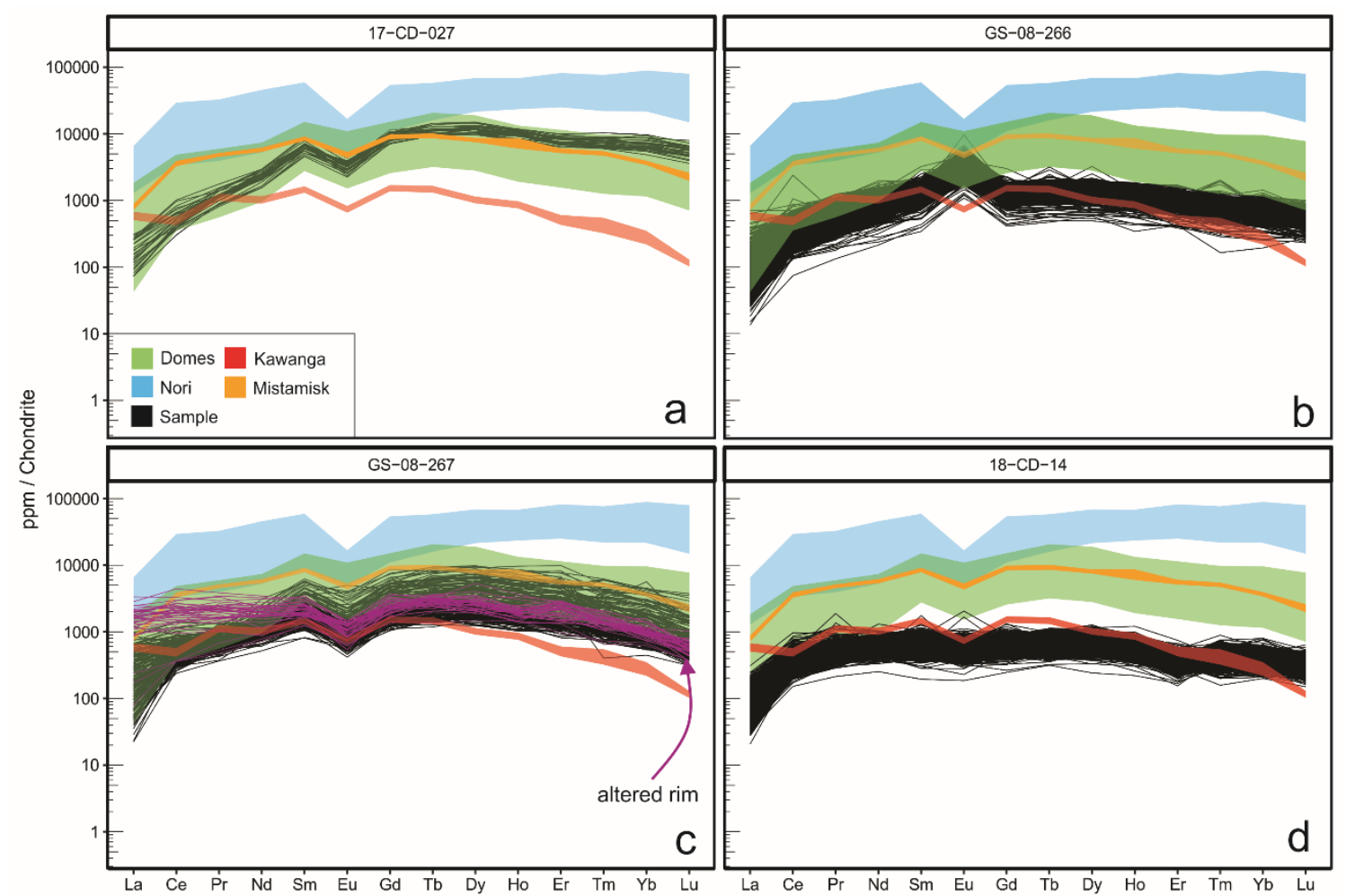

Fig. 2-7: Chondrite normalized REE plots for uraninite from the Kitts deposit (black lines), plotted against data from the Mistamisk veins of Quebec (orange lines, this study), Nori deposit of the Great Bear magmatic zone (blue lines, Potter et al., 2014, accepted), Kawanga deposit of Zambia (red lines, Mercadier et al., 2011), and Domes region of Zambia respectively (green lines, Eglinger et al., 2013).

Group 2 has the second lowest REE chondrite normalized abundances overall (Fig. 2-7b), with a median value of $\Sigma$ REEs $=0.21$ wt\%. Heavy REE are enriched relative to LREE, but the former have relatively flat profiles, and higher concentrations relative to those of Group 1. The LREE are enriched from La through Eu and a strong positive Eu anomaly occurs only in this sample (GS-08-266). Lanthanum abundances are low compared to all other elements. The U/Th ratios vary between 412 and 3593, with a median value of 1229 (Table 2-5). Group 2 uraninite is enriched in $\mathrm{Zr}$ (up to 30000 ppm), and slightly enriched in W (up to $290 \mathrm{ppm}$ ). A late iron oxide vein, enriched in W 
(up to $1330 \mathrm{ppm}$ ), Mo (up to $280 \mathrm{ppm}$ ), and $\mathrm{Ni}$ (up to $250 \mathrm{ppm}$ ), crosscuts the uraninite grains (Fig. 2-5b).

Group 3 has the highest REE chondrite normalized abundances overall (Fig. 2$7 a, c)$ with a median value for $\Sigma$ REEs of 0.38 wt\%. Heavy rare earth elements are enriched relative to $L R E E$, decreasing in abundance from Dy through $L u$, and a LREE increase from La to Sm, resulting in a pseudo-bell shaped pattern with a strong negative Eu anomaly. Lanthanum is depleted relative to all the other REE. The U/Th ratios span from 438 to 17656 and have a median value of 1413 (Table 2-5). Group 3 uraninite is enriched in $\mathrm{Zr}$ (up to $5500 \mathrm{ppm}$ ), Mo (up to $8100 \mathrm{ppm}$ ) and Nb (up to $46 \mathrm{ppm}$ ), and seems to be more enriched in $\mathrm{Zr}$, La and Mo in the rim of uraninite (Fig. 2-10e,f,g, Fig. 29d). A U, La and ${ }^{206} \mathrm{~Pb}$ enrichment of $0.2 \mathrm{wt} \%, 30 \mathrm{ppm}$ and $10000 \mathrm{ppm}$, respectively, is present along fractures and grain boundaries trending away from the uraninite (Fig. 210b,c,g), while HREE (e.g., Lu; Fig. 2-10h) remain in the uraninite. Remobilization of uranium is visible along fractures within the amphibole grain (Fig. 2-11b).

Upon inspection of the trace element maps in sample GS-08-267 (Fig. 2-7c), which indicates the presence of primary uraninite rimmed by a secondary uraninite alteration rim, the uraninite data was re-filtered using $60 \mathrm{wt} \% \mathrm{\cup O}_{2},<3 \mathrm{wt} \% \mathrm{SiO}_{2}$ and $\mathrm{Mo}$ (altered rim > $90 \mathrm{ppm} \mathrm{Mo;} \mathrm{core} \mathrm{<} 90 \mathrm{ppm} \mathrm{Mo}$ ) as threshold values to incorporate the secondary event. The uraninite rim is enriched in $\mathrm{La}, \mathrm{Mo}$ and $\mathrm{Zr}$ relative to the cores, with up to 3363 ppm La, 386 ppm Mo and 611 ppm Zr (median of 183 ppm) in the rim compared to 2278 ppm La, 87 ppm Mo and 6831 ppm Zr (median of 74 ppm) in the core (Fig. 2-7c). 
A uraninite grain from the Mistamisk deposit was analyzed by in-situ LA-ICP-MS as an external standard (composition reported by Lach et al., 2013) and for comparison with the Kitts uraninite. The data is presented in Table 6. 
Table 2-5: Representative trace element data of uraninite from LA-ICP-MS (in ppm), filtered to lower detection limits. Top row is the sample number, second row gives the location number analyzed on the sample.

\begin{tabular}{|c|c|c|c|c|c|c|c|c|c|c|c|c|c|c|c|c|}
\hline & \multicolumn{4}{|c|}{$18-C D-14 b$} & \multicolumn{4}{|c|}{ GS-08-266 } & \multicolumn{4}{|c|}{ GS-08-267 } & \multicolumn{4}{|c|}{$17-C D-027$} \\
\hline & 1 & LLD & 2 & LLD & 1 & LLD & 2 & LLD & 1 & LLD & 2 & LLD & & LLD & & LLD \\
\hline$Y$ & 1009 & 0.018 & 1287 & 0.002 & 1646 & 0.038 & 1442 & 0.029 & 2414 & 0.045 & 2077 & 0.036 & 15563 & 0.036 & 15283 & 0.036 \\
\hline $\mathrm{Zr}$ & 1708 & 0.035 & 6792 & 0.002 & 5598 & 0.075 & 4504 & 0.065 & 669 & 0.093 & 127 & 0.097 & 1436 & 0.052 & 2005 & 0.052 \\
\hline $\mathrm{Nb}$ & 1.71 & 0.021 & 3.53 & 0.005 & 51.2 & 0.330 & 6.25 & 0.030 & 0.054 & 0.054 & 5.22 & 0.048 & 24.4 & 0.028 & 21.4 & 0.028 \\
\hline Cs & - & - & - & - & - & - & - & - & - & - & - & - & 140 & 0.231 & 1423 & 0.231 \\
\hline $\mathrm{Ba}$ & 0.175 & 0.175 & 6.75 & 0.061 & 7.86 & 0.213 & 12.3 & 0.222 & 0.286 & 0.286 & 40.3 & 0.278 & 13.2 & 0.246 & 23.7 & 0.246 \\
\hline La & 13.5 & 0.011 & 16.8 & 0.015 & 35.9 & 0.028 & 21.9 & 0.032 & 23.0 & 0.031 & 233 & 0.029 & 19.4 & 0.029 & 73.8 & 0.029 \\
\hline $\mathrm{Ce}$ & 169 & 0.000 & 194 & 0.006 & 186 & 0.021 & 151 & 0.027 & 267 & 0.039 & 847 & 0.026 & 233 & 0.028 & 384 & 0.028 \\
\hline $\operatorname{Pr}$ & 43.0 & 0.013 & 43.9 & 0.003 & 51.6 & 0.015 & 36.1 & 0.020 & 62.9 & 0.027 & 151 & 0.022 & 81.2 & 0.020 & 114 & 0.020 \\
\hline $\mathrm{Nd}$ & 261 & 0.000 & 338 & 0.035 & 297 & 0.152 & 340 & 0.124 & 644 & 0.167 & 826 & 0.123 & 883 & 0.085 & 1144 & 0.085 \\
\hline Sm & 84.0 & 0.042 & 141 & 0.038 & 160 & 0.100 & 149 & 0.132 & 406 & 0.189 & 236 & 0.123 & 850 & 0.147 & 911 & 0.147 \\
\hline $\mathrm{Eu}$ & 32.7 & 0.013 & 52.9 & 0.018 & 160 & 0.042 & 154 & 0.042 & 51.7 & 0.065 & 48.3 & 0.041 & 152 & 0.037 & 183 & 0.037 \\
\hline $\mathrm{Gd}$ & 128 & 0.121 & 183 & 0.103 & 248 & 0.147 & 208 & 0.187 & 513 & 0.205 & 373 & 0.176 & 1602 & 0.191 & 1740 & 0.191 \\
\hline $\mathrm{Tb}$ & 20.8 & 0.015 & 30.3 & 0.014 & 50.2 & 0.023 & 45.0 & 0.016 & 107 & 0.022 & 97.8 & 0.026 & 378 & 0.020 & 360 & 0.020 \\
\hline Dy & 150 & 0.052 & 265 & 0.028 & 334 & 0.081 & 297 & 0.050 & 766 & 0.145 & 548 & 0.117 & 2457 & 0.090 & 2634 & 0.090 \\
\hline Ho & 31.0 & 0.018 & 31.5 & 0.015 & 48.7 & 0.019 & 56.3 & 0.023 & 145 & 0.035 & 112 & 0.031 & 445 & 0.028 & 550 & 0.028 \\
\hline $\mathrm{Er}$ & 54.3 & 0.016 & 76.7 & 0.046 & 142 & 0.087 & 153 & 0.085 & 269 & 0.090 & 309 & 0.161 & 1046 & 0.086 & 1250 & 0.086 \\
\hline $\mathrm{Tm}$ & 9.05 & 0.006 & 12.0 & 0.007 & 15.7 & 0.014 & 16.2 & 0.014 & 30.5 & 0.023 & 35.2 & 0.028 & 159 & 0.019 & 184 & 0.019 \\
\hline $\mathrm{Yb}$ & 63.9 & 0.127 & 91.3 & 0.064 & 112 & 0.130 & 114 & 0.105 & 140 & 0.174 & 126 & 0.152 & 961 & 0.152 & 954 & 0.152 \\
\hline Lu & 8.10 & 0.022 & 12.8 & 0.019 & 10.1 & 0.023 & 15.2 & 0.017 & 15.0 & 0.034 & 11.4 & 0.031 & 104 & 0.023 & 117 & 0.023 \\
\hline $\mathrm{Hf}$ & 7.87 & 0.057 & 29.8 & 0.062 & 26.1 & 0.069 & 26.7 & 0.066 & 2.81 & 0.103 & 0.931 & 0.096 & 10.2 & 0.089 & 16.8 & 0.089 \\
\hline $\mathrm{Ta}$ & 0.023 & 0.023 & 0.011 & 0.011 & 2.10 & 0.024 & 0.116 & 0.023 & 0.253 & 0.030 & 0.738 & 0.022 & 2.49 & 0.023 & 2.92 & 0.023 \\
\hline $\mathrm{Bi}$ & 2.09 & 0.052 & 4.22 & 0.041 & 3.16 & 0.072 & 4.89 & 0.069 & 1.36 & 0.084 & 0.992 & 0.063 & 1.84 & 0.060 & 9.12 & 0.060 \\
\hline Th & 220 & 0.024 & 375 & 0.023 & 479 & 0.032 & 599 & 0.037 & 608 & 0.039 & 126 & 0.038 & 1073 & 0.036 & 1058 & 0.036 \\
\hline
\end{tabular}


Table 2-6: Average REE contents of Mistamisk uraninite compared to analyses by Lach et al. (2013). Analyses by LA-ICP-MS in this study, with error reported in 1 standard deviation $(\sigma)$.

\begin{tabular}{|ccc|c|c|}
\hline & \multicolumn{2}{c|}{ This study $(n=39)$} & \multicolumn{2}{c|}{ Lach et al. (2013) $(n=40)$} \\
& AVG & $\sigma$ & AVG & $\sigma$ \\
\hline \hline La & 279 & 42 & 275 & 68 \\
$\mathrm{Ce}$ & 2981 & 278 & 2783 & 488 \\
$\mathrm{Pr}$ & 620 & 55 & 520 & 78 \\
$\mathrm{Nd}$ & 3937 & 359 & 3266 & 494 \\
$\mathrm{Sm}$ & 1790 & 201 & 1393 & 183 \\
$\mathrm{Eu}$ & 348 & 49 & 266 & 39 \\
$\mathrm{Gd}$ & 1710 & 233 & 1380 & 195 \\
$\mathrm{~Tb}$ & 336 & 48 & 285 & 45 \\
$\mathrm{Dy}$ & 2294 & 346 & 1918 & 336 \\
$\mathrm{Ho}$ & 405 & 62 & 335 & 55 \\
$\mathrm{Er}$ & 889 & 153 & 850 & 141 \\
$\mathrm{Tm}$ & 117 & 19 & 89 & 14 \\
$\mathrm{Yb}$ & 640 & 102 & 490 & 79 \\
$\mathrm{Lu}$ & 54 & 9 & 44 & 7 \\
\hline
\end{tabular}




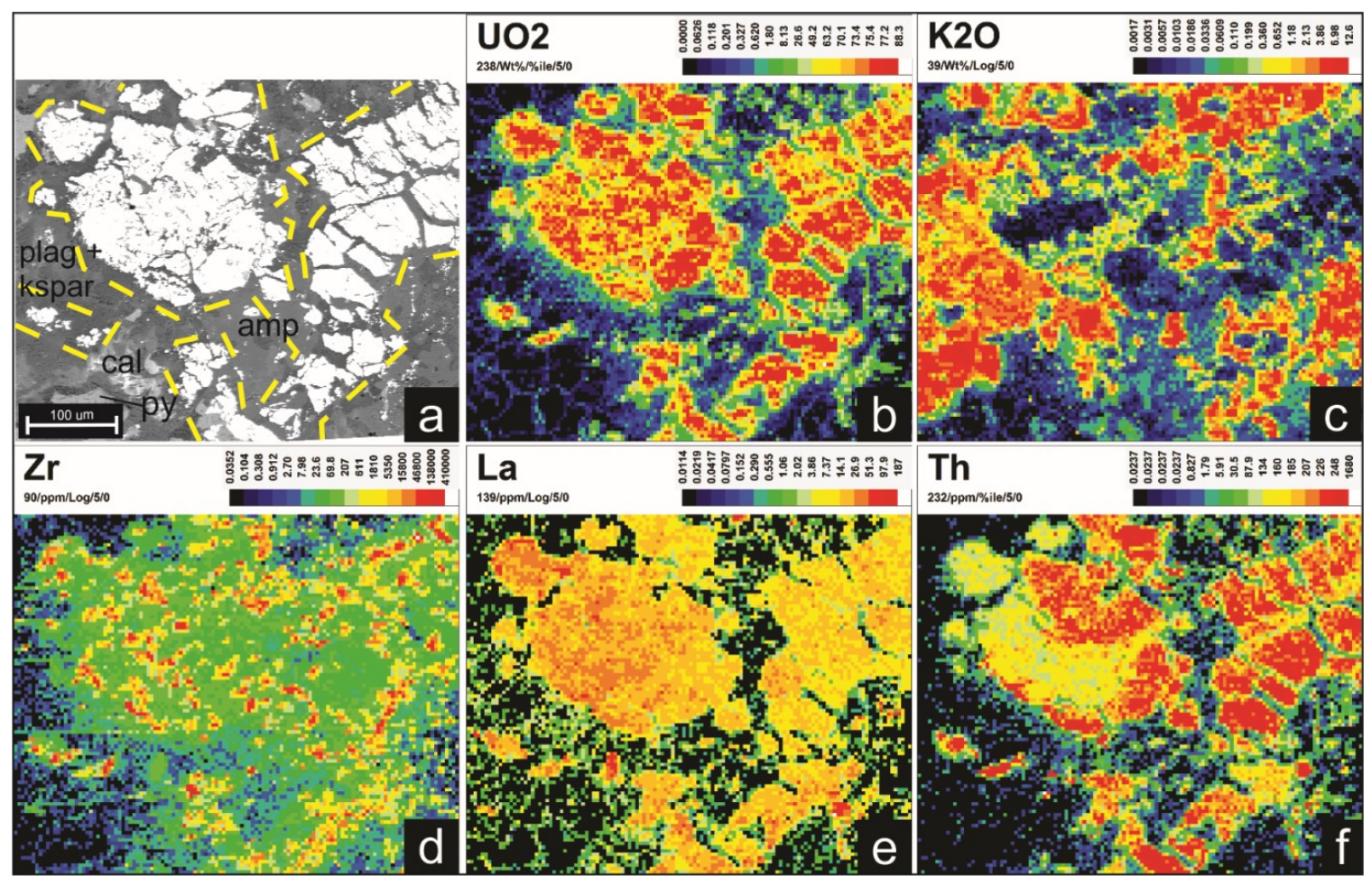

Fig. 2-8: LA-ICP-MS element maps of coarse-grained uraninite and pyrite in albite and amphibole from sample 18-CD-014b (Group 1) of the Kitts deposit. 


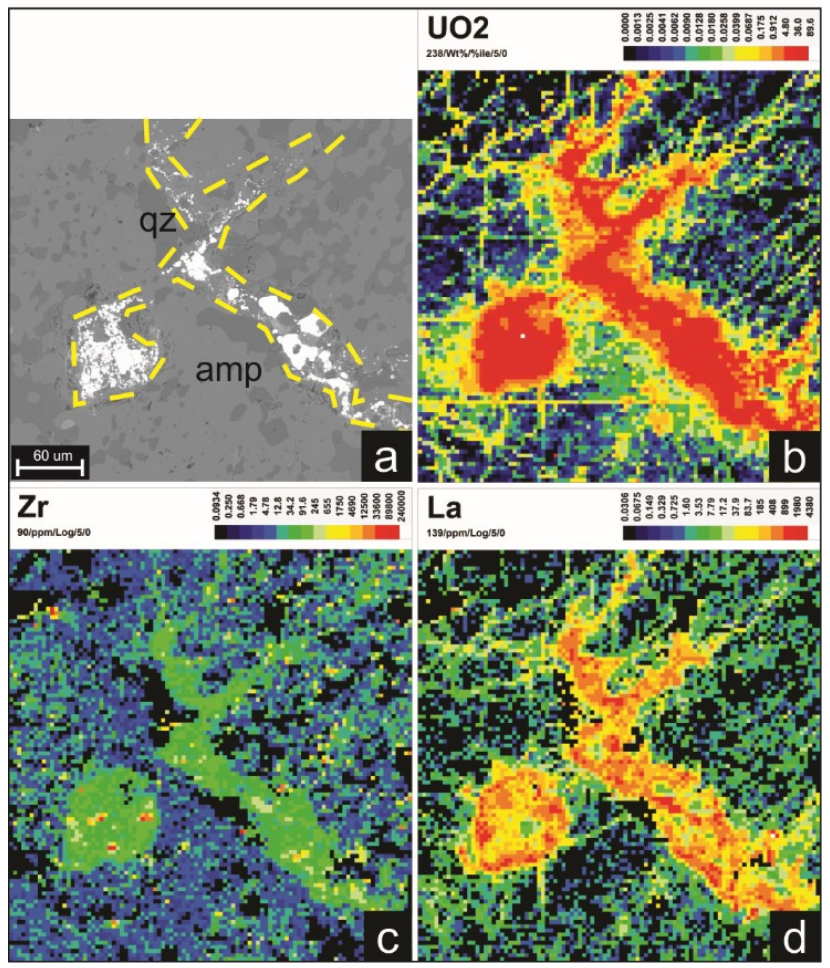

Fig. 2-9: LA-ICP-MS element maps of a fine-grained uraninite veinlet cutting amphibole and quartz from sample GS-08-267 (Group 3) of the Kitts deposit.

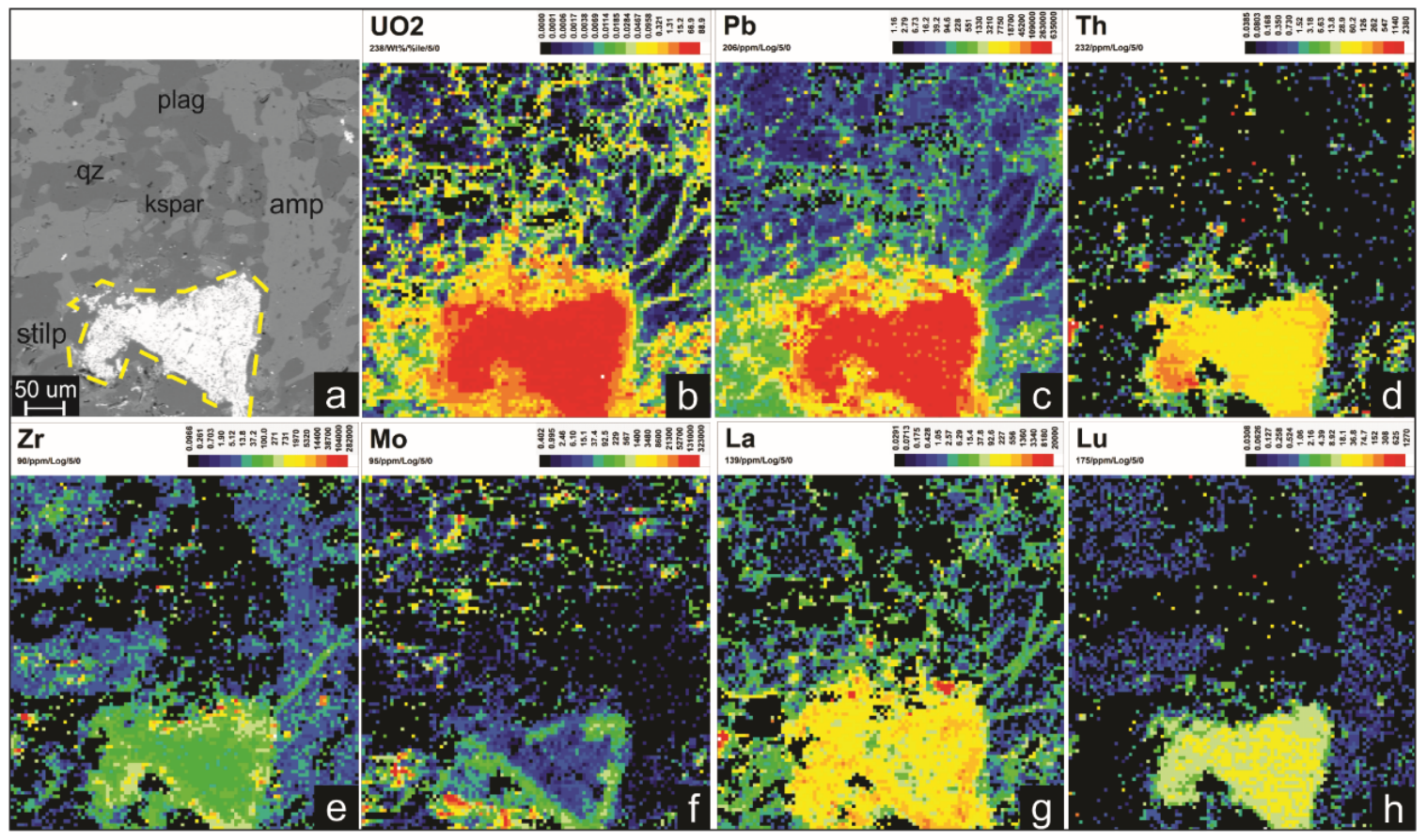

Fig. 2-10: LA-ICP-MS element maps of coarse-grained uraninite in albite, K-feldspar, amphibole and quartz from sample GS-08-267 (Group 3) of the Kitts deposit, highlighting the remobilization of $\mathrm{U}(\mathrm{b}), \mathrm{Pb}(\mathrm{c})$ and $\mathrm{La}(\mathrm{g})$ from uraninite along fractures. 


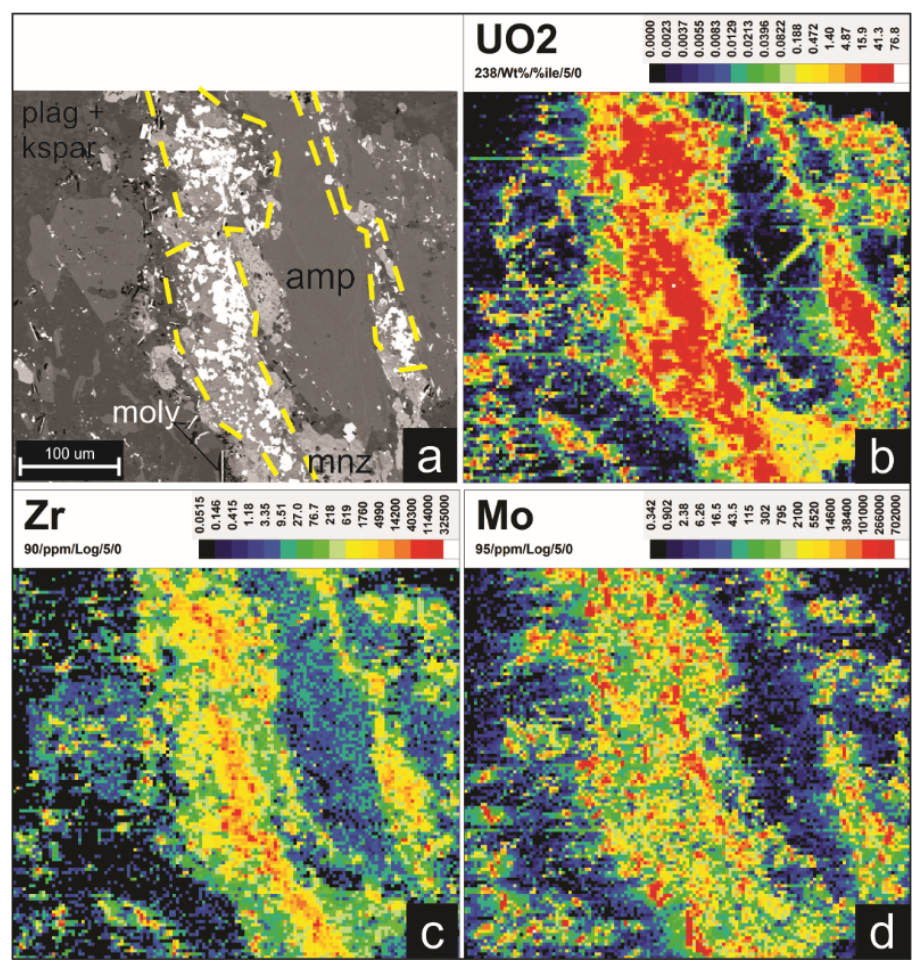

Fig. 2-11: LA-ICP-MS element maps of fine-grained uraninite-monazite-molybdenite veinlets cutting albite, amphibole and K-feldspar from sample 17-CD-27 (Group 3) of the Kitts deposit.

\subsection{Discussion}

\subsubsection{IOAA facies in the Kitts-Post Hill belt}

Despite the poorly constrained timing and metallogenic processes in the Kitts-

Post Hill belt (Gandhi, 1978; Evans, 1980; Wilton and Wardle, 1987; Wilton and

Longerich, 1993), a metasomatic-hydrothermal origin for these fluids is implied from uranium mineralization associated with alkali metasomatism, metamorphicmetasomatic minerals, and a whole-rock U-Zr correlation (Evans, 1980; Sparkes and Kerr, 2008). However, there is still a knowledge gap relative to the spatial and temporal association of the Kitts-Post Hill belt occurrences with other mineralized areas in the $\mathrm{CMB}$, as well as a comparison to analogous hydrothermal uranium deposits globally. 
Uraninite inclusions within amphibole and cross-cutting vein-like textural types of uraninite noted in this study are in agreement with previous work of Evans (1980), Gandhi (1978) and Marten (1977) suggesting syn-metamorphic and structurally controlled uranium mineralization. Further inspection of the samples revealed the presence of pervasive $\mathrm{Na}$ and $\mathrm{Ca}-\mathrm{Fe}$ facies alteration assemblages in the form of $\mathrm{Na}$ plagioclase and Ca-Fe amphibole (often in veins), respectively, throughout the sample suite, consistent with the reported $\mathrm{Na}$ and $\mathrm{Ca}$-Fe alteration overprinting the argillite at the Kitts deposit (Evans, 1980).

The uranium mineralization style, host rocks and alteration of the Kitts-Post Hill belt are comparable to those of the Southern Breccia and Nori occurrences of the Great Bear magmatic zone, albitite-hosted uranium deposits of Central Ukraine and Domes region, uranium deposits of Zambia and the Mistamisk albitite veins of Quebec. Uranium mineralization of all these deposits is hosted in metasedimentary rocks (with the exception of some granitic-hosted deposits in Central Ukraine), which have experienced similar $\mathrm{Na}, \mathrm{Ca}(+/-\mathrm{Mg}, \mathrm{Fe})$ and $\mathrm{K}-$ Fe metasomatic alteration, metamorphic conditions and are controlled by tectonic/deformational structures.

Uraninite mineralization from the Kitts-Post Hill and the Southern Breccia (Montreuil et al., 2015) is hosted by metasedimentary rocks and locally associated with pyrite-chalcopyrite-molybdenite that precipitated in high-temperature K-Fe alteration facies. Accessory minerals such as allanite, galena, barite and scheelite observed in the Kitts-Post Hill belt are also present at the Southern Breccia (cf. Montreuil et al., 2015; Potter et al., 2019). In the Gear deposit, co-precipitation of uraninite with 
clinopyroxene, amphibole, magnetite, andradite and talc is consistent with skarn-type alteration described in the Great Bear magmatic zone, often spatially associated with Na-alteration (Corriveau et al., 2016; Montreuil et al., 2016), and Central Ukraine albitite-hosted uranium deposits (Cuney et al., 2012).

The Nori occurrence of the Great Bear magmatic zone is hosted in metasiltstones associated with stratabound to discordant, high-temperature K-Fe facies assemblages (Gandhi, 1994; Ootes et al., 2010). Regionally, the Nori occurrence records $\mathrm{Na}$ (albite) facies alteration, high-temperature Ca-Fe facies alteration (amphibole, amphibole-magnetite and magnetite) and K-Fe facies alteration (+/-magnetite-Kfeldspar breccia zones) (Corriveau et al., 2007, 2018). These observations led Corriveau et al. $(2007,2018)$ and Ootes et al. (2010) to suggest that the showings represent an early expression of an IOCG deposit within a regional IOAA system. Unlike uraninite mineralization observed in the Kitts-Post Hill belt, uraninite from the Nori occurrence is hosted in biotite-magnetite veins, associated with tourmaline, K-feldspar, molybdenite, allanite, pyrite and chalcopyrite (Ootes et al., 2010). However, the host rocks and alteration style is similar to that observed within the Kitts-Post Hill belt sample suite.

The Kitts-Post Hill belt mineralization is also similar to that of the Central Ukraine deposits in that uranium mineralization is hosted in the K-Fe alteration facies, and the deposits are characterized by similar Na and Ca-Fe alteration (Cuney et al., 2012). In the albitite-hosted uraninite deposits of Central Ukraine, andradite alteration is similar to that of the Gear deposit, and occurs in high temperature Ca-Fe alteration facies (Cuney et al., 2012). In the Central Ukraine, K-Fe alteration facies hosting uranium 
mineralization comprises calcite, biotite, iron oxide and sulfides; somewhat similar to the uraninite-calcite-hematite vein-hosted assemblage observed in the Kitts-Post Hill belt (Evans, 1980; Sparkes, 2017).

The Domes region of the Pan-African Lufilian belt in Zambia is host to both copper and cobalt deposits, as well as syn-metamorphic uranium occurrences (Meneghel, 1981; Mercadier et al., 2011; Eglinger et al., 2013, 2014). The host rocks to the mineralization are dominantly carbonaceous quartzite and quartz mica schist, where fluid inclusions in syn-metamorphic quartz veins suggest two uranium mineralization events (Meneghel, 1981; Eglinger et al., 2014). Similar to the Kitts-Post Hill belt, uranium mineralization is associated with amphibolite facies metamorphism and $\mathrm{Ca}-\mathrm{Na}$ metasomatism (Eglinger et al., 2014) in the area.

Kish and Cuney (1981) described the Mistamisk uranium deposit as uraninitealbite veins hosted in an argillite unit, where the wall-rock has been pervasively Nametasomatized and metamorphosed to greenschist facies, furthermore locally constrained weak to moderate $\mathrm{K}$-alteration has been recognized in the Mistamisk boulder field (Desrochers, 2016). Widespread IOAA type alteration ( $\mathrm{Na}, \mathrm{Ca}-\mathrm{Fe}$, high- and low-temperature K-Fe facies) led Corriveau et al. (2014) to propose a possible linkage between the Mistamisk deposit and a regional IOAA system. These alteration facies were confirmed by drilling and exploration work done in the Romanet-Horst area on the Sagar property (Desrochers, 2016). The Mistamisk deposit and Kitts-Post Hill belt have similar host rocks, local and regional alteration facies and regional metamorphic conditions. 
Using limited whole rock geochemistry of the Kitts-Post Hill belt from Acosta-

Góngora et al. (2018) geochemical dataset and the Montreuil et al. (2013) IOCG discrimination plot, samples from the Kitts-Post Hill belt exhibit $\mathrm{Na}, \mathrm{Ca}-\mathrm{Fe}, \mathrm{K}-\mathrm{Fe}$ and $\mathrm{K}$ facies alteration typical of IOAA systems (Fig 2-12b). The presence of these alteration facies is supported by combining the element molar proportion "bar codes" of Corriveau et al. (2018) to illustrate the significant $\mathrm{Na}, \mathrm{Ca}-\mathrm{Fe}$ and in some cases, $\mathrm{K}-\mathrm{Fe}$ and $\mathrm{K}$ alteration relative to unaltered rock types (Fig 2-12a). The presence of potential Kbearing alteration is particularly interesting, as this type of alteration has not been reported in the Kitts-Post Hill district.
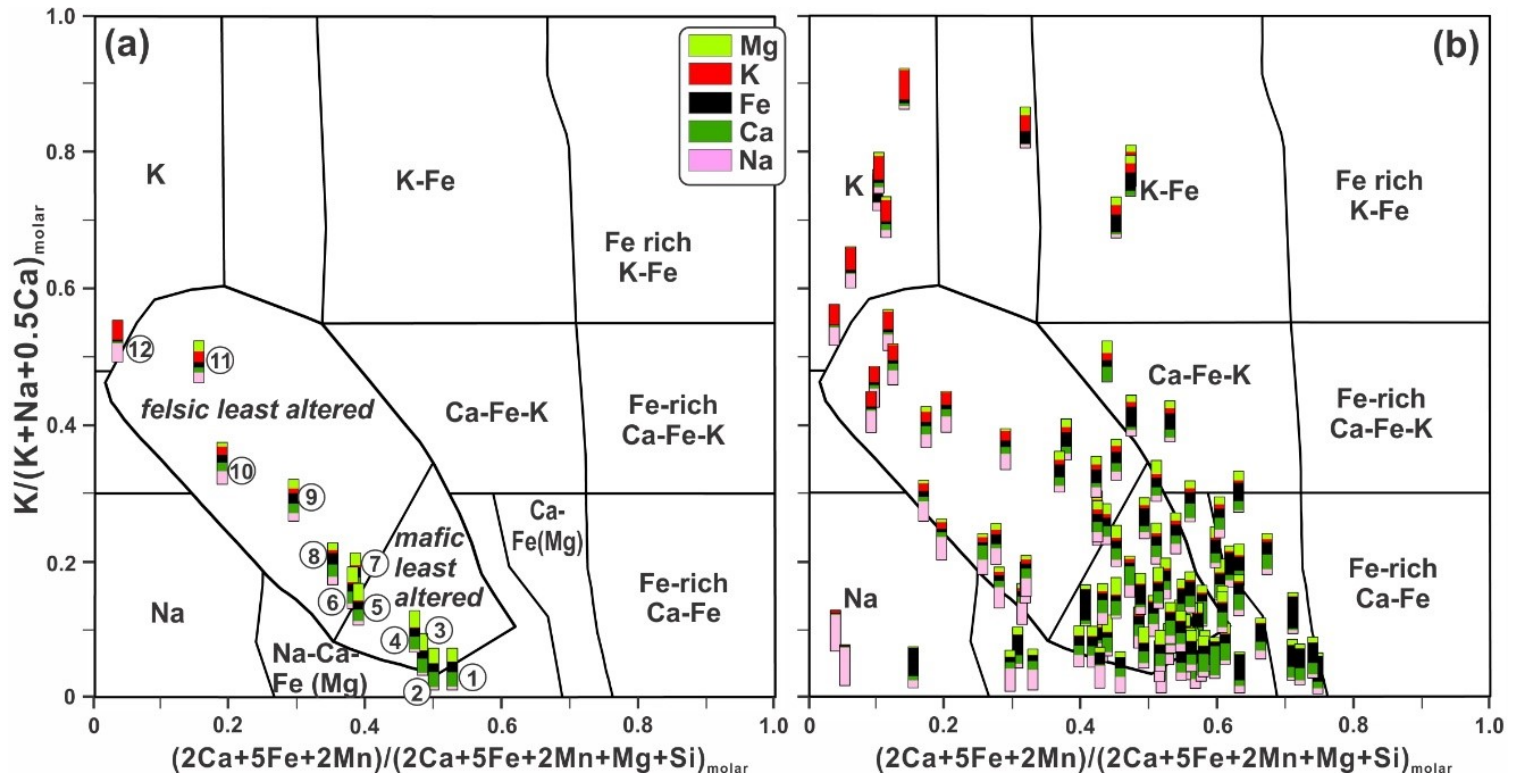

Fig 2-12: IOCG alteration discrimination plot of Montreuil et al. (2013) combined with the molar proportion "bar codes" of Corriveau et al. (2018) illustrating: (a) the composition of unaltered rock types selected from published data modified from Potter et al. (in press) and (b) the presence of IOAA facies in the Kitts-Post Hill trend. Reference rock types from: 1 - Keleman et al. (2014); 2 - Gale et al. (2003); 3 to 6 - Keleman et al. (2014); 7 -Rudnick and Gao (2014); 8 \& 10 - Kemp and Hawkesworth (2005); 9 - Rudnick and Gao (2014); 11 \& 12 - Pearce et al. (1984). 
In summary, the Kitts-Post Hill belt is characterized by multiple alteration facies typical of IOAA-type deposits ( $\mathrm{Na}, \mathrm{Ca}-\mathrm{Fe}$ and $\mathrm{K}-\mathrm{Fe}$ ), where uraninite is hosted in Ca-Fe alteration, in spatial and syn-genetic association with K-Fe alteration (Corriveau et al., $2010,2016)$. The host rocks, alteration and mineralization of the Kitts-Post Hill belt is similar to other known IOAA-type deposits worldwide.

\subsubsection{Geochemistry}

Based on chondrite-normalized REE patterns, three different populations of uraninite are recognized within the Kitts deposit. Based on the REE and HFSE element concentrations, uraninite grains from Kitts seem to record variable temperature conditions where the majority of data reflect low temperature hydrothermal conditions, although there does seem to be a higher temperature signature (Fig. 2-13). These compositional differences could reflect two distinct types of uranium-rich fluids: a primary higher temperature event followed by subsequent remobilization or alteration of uraninite by later lower temperature hydrothermal fluids. 


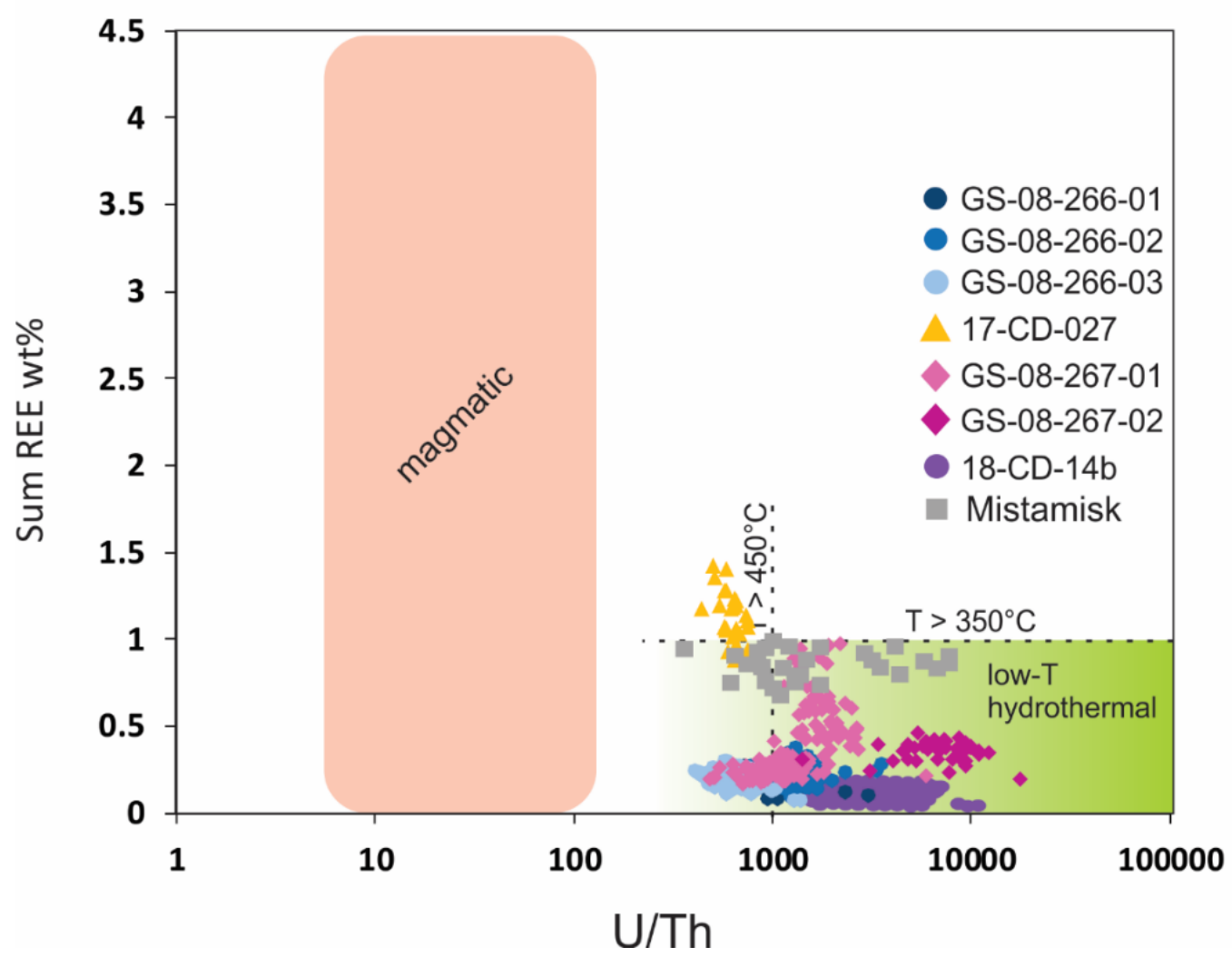

Fig. 2-13: REE sum (wt \%) versus U/Th of samples analyzed by LA-ICP-MS, modified from Frimmel et al. (2014).

The contrasting Eu anomalies could be interpreted as a variation in oxygen fugacity between the primary and remobilizing fluids (Drake, 1975). As such, these anomalies could reflect fluids that have interacted with plagioclase-rich rocks, where by the $\mathrm{Ca}^{2+}$ site in the plagioclase and Ca-Fe amphibole, which selectively concentrated Eu during crystallization, releases Eu when altered (Lottermoser, 1992). The positive Eu anomaly may be a result of uraninite having formed post-albite (Na facies) and Ca-Fe amphibole (Ca-Fe facies), from fluids that interacted with these minerals. Positive Eu anomalies in uraninite REE chondrite normalized patterns are rare (Frimmel et al., 2014), although notably there is a positive anomaly observed in some uraninite patterns 
of the Pan-African Lufilian belt (Eglinger et al., 2014), which was interpreted as a factor of high oxygen fugacity of the mineralizing fluid.

Widespread hematization has been described throughout the CMB (Gower et al., 1982; Sparkes and Kerr, 2008; Sparkes et al., 2016). Potter et al. (accepted) propose that primary uranium precipitation in IOAA systems occurs during the reduced, high temperature $\mathrm{K}-\mathrm{Fe}$ (magnetite) facies alteration as the fluid temperatures decrease and pH changes, supporting experimental work by Timofeev et al. (2018) that noted the presence of an $\mathrm{UCl}_{4}$ species that is stable under acidic and reduced conditions. These results challenge the long-standing hypothesis that $\mathrm{U}^{4+}$ is immobile, and confirm that uranium enrichment in these high temperature systems does not require oxidized fluids enriched in $\mathrm{U}^{6+}$.

Uranium mineralization in the Kitts-Post Hill belt sample suite is always associated with potassium, often in the form of fine-grained K-feldspar but also accessory minerals such as stilpnomelane. In the Gear deposit, uranium mineralization is associated with magnetite, and possibly hematite. Subsequent dissolutionreprecipitation and remobilization of primary uraninite can occur during the transition from magnetite to hematite-bearing K-Fe alteration, expanding the uranium potential in IOCG systems from magnetite-to hematite-bearing deposits. The transition from magnetite to hematite reflects the increasing oxidation state of the fluid (Hemmingway, 1990; Corriveau et al., 2016). This is possible supporting evidence for the interpretation that the positive Eu anomalies in chondrite normalized REE patterns of Group 2 uraninite reflect remobilization by oxidized fluids. 
Uraninite REE chondrite normalized patterns have been shown to reflect the mineralizing source fluid or deposit type of the uraninite (Mercadier et al., 2011; Frimmel et al., 2014). Uraninite LA-ICP-MS data from the Mistamisk deposit (Lach et al., 2013; this study) yielded REE chondrite normalized patterns with some similarities to uraninite from the Kitts-Post Hill belt (Fig. 2-7). In particular, both deposits exhibit a bell to pseudo-bell shaped pattern (Fig. 2-7), high U/Th ratios (Fig. 2-13) and similar total REE concentrations in Group 3 uraninite. The Mistamisk data (Lach et al., 2013; this study) also plot within the low-temperature hydrothermal field, close to or overlapping the Kitts data (Fig. 2-13). However, as shown by the LREE mobility during alteration of uraninite (Figs. 2-9, 2-10), the temperature estimates based on $\Sigma$ REE (Fig. 2.13) may be less robust than estimates based on U/Th values. In summary, a similar fluid source may be inferred based on uraninite geochemistry, host rocks, metamorphic conditions and alteration facies for the Kitts and the Mistamisk deposits.

Similar to the CMB deposits, uranium oxides of the Central Ukraine albititehosted uranium deposits and some uraninite grains from the Nori uranium occurrence have high U/Th ratios (Cuney et al., 2012; Potter et al., accepted). Uraninite from the Nori occurrence has similar chondrite normalized REE patterns as the Kitts deposit, in particular Group 3, which has the highest concentration of REE. However, the elevated REE contents and chondrite-normalized patterns of the Nori prospect uraninite is indicative of formation by magmatic-hydrothermal fluids, which is inconsistent with the temperature suggested by the U/Th ratios from the Kitts uraninite. 
Eglinger et al. (2013) describe chondrite normalized REE patterns for uraninite of deposits in the Domes region, which overlap with Group 3 of this study (Fig. 2-7a,c). The similar chondrite normalized REE patterns, combined with the similar previously described alteration and metamorphic conditions, point to a similar metasomaticmetamorphic fluid source between Group 3 uraninite and the Domes Region uraninite. While Group 1 uraninite do not overlap with the Domes Region uraninite patterns, it is very similar to the Kawanga deposit, a syn-metamorphic deposit within the Domes Region (Mercadier et al., 2011).

Martz et al. (2019) used variable REE contents in uraninite from unconformitytype uranium deposits to propose the presence of multiple generations of uraninite in the deposit. The authors propose that uraninite LREE contents increases significantly with increasing alteration while HREE contents decrease slightly. Molybdenum enrichment was chosen to represent the threshold for significant alteration, as there is a clear Mo-La enrichment in the rim of sample GS-08-267 (Fig. 2-10). The LREE (La-Sm) are clearly enriched in the altered rim compared to the core, while the HREE (Eu-Lu) are similar for both the altered and "unaltered" REE pattern. This LREE enrichment in uraninite with increasing alteration confirms the results of Martz et al. (2019), showing that LREE in particular, may be more easily mobilized in uraninite than previously thought (Fig. 2-7c).

A zirconium enrichment observed in the uraninite of the Kitts deposit is similar to uranium oxides within the albitite-hosted uraninite of Central Ukraine (Cuney et al., 2012) and Southern Breccia corridor (Potter et al., 2019; accepted). Cuney et al. (2012) 
and Montreuil et al (2016) propose high temperature, alkaline fluids (i.e., elevated $\mathrm{Na}+/ \mathrm{K}+$ and $\mathrm{Na}+/ \mathrm{H}+$ ratios) during $\mathrm{Ca}-\mathrm{Fe}$ metasomatism. Alkaline $\mathrm{pH}$ favours elevated uranium and zirconium solubilities as hydroxyl complexes (Romberger, 1984; Wood, 2005) and weak mobility of Ca, Mg and Fe (Azimov and Bushmin, 2007). In the literature, zirconium mobility in hydrothermal fluids is often linked to formation of fluoride and hydroxyfluoride species at high temperatures (Keppler and Wyllie, 1990; Salvi et al., 2000; Wood, 2005; Migdisov et al., 2009, 2011). However, precipitation of Ca-bearing minerals (Ca-Fe amphibole, apatite) prior to and during primary uranium mineralization is problematic as the presence of $\mathrm{Ca}$ in fluids greatly diminishes the capacity to transport Zr and REE as fluoride complexes given the stability of fluorite (Wood, 2005). One mechanism to explain the presence of Ca-bearing minerals and $\mathrm{Zr}$ enrichment in uraninite is the interaction of F-bearing fluids undersaturated in Ca with respect to fluorite $\left(\mathrm{CaF}_{2}\right)$ with a local Ca source (e.g., carbonate rocks) or Ca-bearing fluids (Woods, 2005). This would cause precipitation of fluorite, destabilizing the metal fluoride complexes in solution and triggering precipitation of these elements. However, no F-bearing minerals were noted in the samples.

Uraninite grains often show grain boundary enrichment of $U, Z r$ and LREE throughout the sample suite (Fig. 2-10). This is possible evidence for incursion of acidic fluids after primary alteration and mineralization. Unlike LREE, HREE are not enriched in the matrix, fractures nor grain boundaries, and are therefore not affected by remobilization in the same way as the LREE (Fig. 2-10g, h). This also confirms HREE stability with increasing alteration proposed by Martz et al. (2019), and that fluids 
altering uraninite may have been $\mathrm{Cl}$-rich, as LREE more mobile in these fluids (Migdisov et al., 2016).

In summary, uraninite of the Kitts deposit has a higher temperature primary signature recorded by the U/Th ratios and total REE contents partially to completely overprinted by a lower temperature hydrothermal signature. Three different REE chondrite normalized patterns are recognized in the Kitts uraninite, suggesting three different populations of uraninite. Uraninite is geochemically similar to other known metasomatic - metamorphic uranium deposits (Mistamisk and the Domes Region). Light $\mathrm{REE}, \mathrm{Zr}$, Mo and Th are enriched in altered rims of some uraninite grains, relative to their cores.

\subsubsection{Mineralization in terms of regional tectono-metamorphic history}

The three separate age peaks defined by EMPA data (Fig. 2-14) and three distinct chondrite-normalized REE uraninite patterns (Fig. 2-7) support the interpretation of at least three uraninite populations within the Kitts deposit. The U/Th ratios and total REE contents of uraninite from the four samples suggest an order of mineralization from oldest to youngest consistent with Group 3>Group 2>Group 1. However, the U-Pb EMPA data of uraninite from the Kitts samples suggest an opposite order of events, with Group 3 as the youngest event and Group 1 as the oldest. The younger $\mathrm{U}-\mathrm{Pb}$ ages may be a factor of $\mathrm{Pb}$ loss, visible in Fig. 2-10c, during one of the many metamorphic / plutonic events in the $\mathrm{CMB}$ (discussed further in section 6.3). Thorium was not as affected as lead during these events, (Fig. 2-10d), as lead is more easily leached from uraninite and mobile than thorium in typical geological fluids (Alexandre \& Kyser, 2005). 


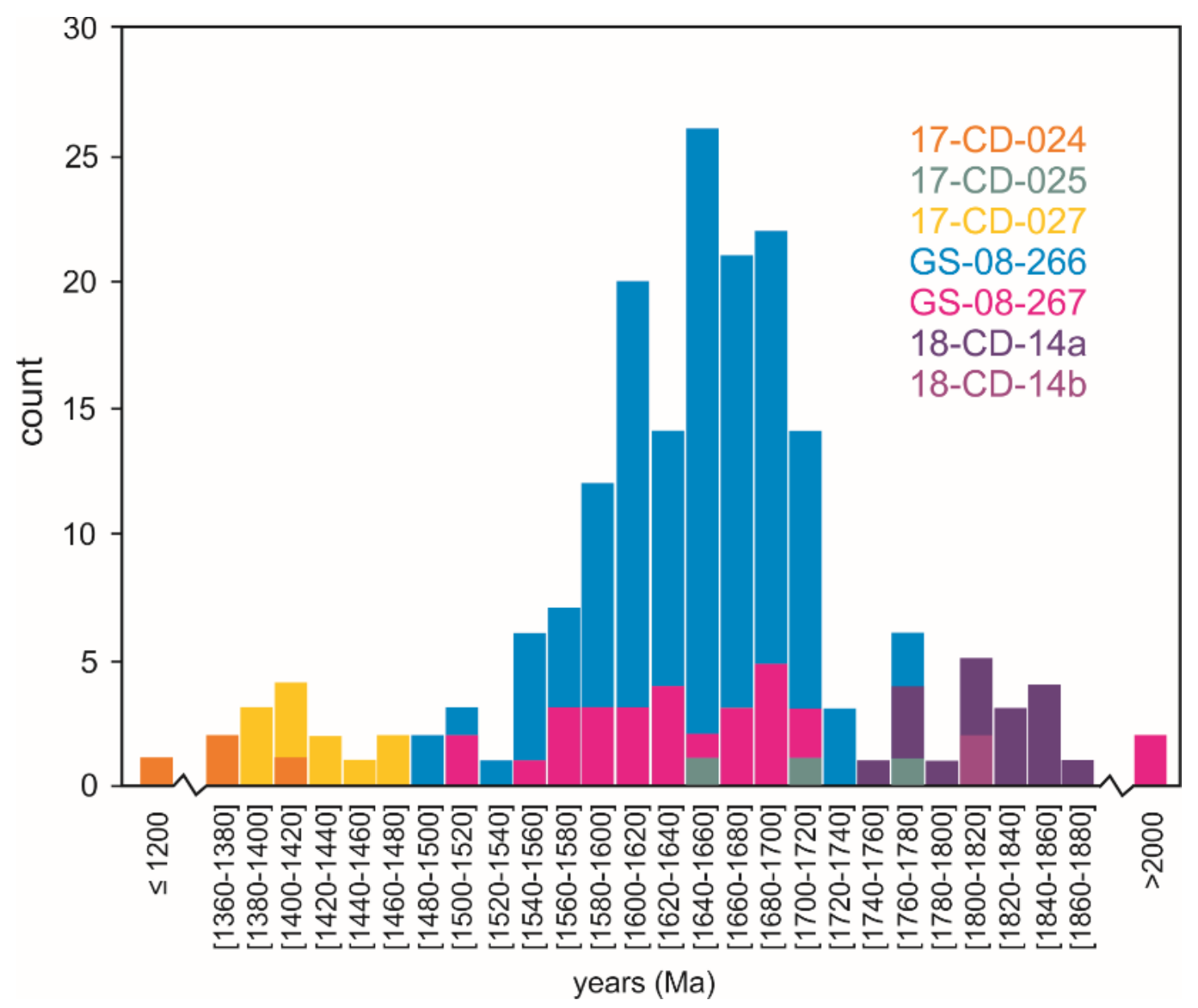

Fig. 2-14: Chemical U-Pb ages for uraninite grains analyzed by EMPA, color-coded to corresponding sample numbers. Ages calculated using Bowles (2015).

Element remobilization in the Kitts-Post Hill belt has been interpreted from uraninite geochemistry, furthermore it is described in multiple studies of the Central Mineral Belt (Sparkes and Kerr, 2008; Tracey, 2009; Sparkes et al., 2010). Mineralization in the Kitts-Post Hill belt has not been dated, but Sparkes et al. (2010) interpret the Kitts primary uranium mineralization as older than 1882 Ma but younger than 2018 Ma based on the pre-mineralization Kitts Metagabbro and a younger, crosscutting dyke. All chemical U-Pb ages (excluding the outliers) suggested in this study are younger than the mineralization age bracket defined by Sparkes et al. (2010), but radiogenic lead loss in 
uraninite older than 1000 Ma causes uncertainty in the absolute ages, therefore absolute ages may actually be older (Bowles, 2015).

The regional-scale tectono-metamorphic events experienced in the area represent potential driving forces for fluid flow, heat production and element remobilization in the area, key ingredients in the development of IOAA type deposits but also subsequent remobilization of metals (Corriveau et al., 2010; Montreuil et al., 2016). The Long Island pluton dated ca. 1802 Ma by Kerr et al. (1992) could represent a potential source of heat for the element remobilization in the Kitts-Post Hill belt, due to its geographic proximity. Younger titanite ages of $1794 \pm 2 \mathrm{Ma}, 1761 \pm 2 \mathrm{Ma}$ and $1746 \pm$ 2 Ma from intrusive rocks in the Kaipokok Bay area suggest that the area was thermally and tectonically active for up to $50 \mathrm{Ma}$ after emplacement of the Long Island pluton, further evidence for the interpretation of multiple uranium remobilization events in the area (Kerr et al., 1992). The peak defined by the largest group of EMPA analyses (1620$1640 \mathrm{Ma}$ ), coincides roughly with the Labradorian orogeny (Nunn et al., 1984), another potential driver for the remobilization of uraninite.

In summary, the EMPA data supports three uraninite populations, which is consistent with a primary uranium event and subsequent uranium remobilization by metasomatic fluids (likely more than one episode) derived from the regional metamorphic events and/or nearby granitic intrusions. 


\subsection{Conclusions}

The alteration and mineral assemblages presented in this study suggest a potential IOAA association (regional $\mathrm{Na}, \mathrm{Ca}-\mathrm{Fe}$, and possibly K-Fe alteration facies with associated uraninite mineralization). More specifically, the Kitts mineralization is geochemically similar to both the Mistamisk deposit, an albitite vein uranium deposit with potential IOAA linkages (Corriveau et al., 2014), and the Domes region deposits of Zambia, where the uranium mineralizing fluid is $\mathrm{Ca}-\mathrm{Na}$ metasomatic in origin (Eglinger et al., 2014).

Differences in uraninite geochemistry point to a complex hydrothermal fluid history, where the primary signatures have been altered by the many regional metamorphic-plutonic episodes, and can be interpreted as three different mineralizing events. The $\mathrm{Zr}$ and Nb enrichment associated with uraninite suggest primary high temperature fluids that are capable of moving HFSE. Enrichment of $\mathrm{Zr}$, LREE, $\mathrm{U}$ and $\mathrm{Pb}$ along grain boundaries and fractures within the matrix support late-remobilization of these elements during alteration of the uraninite. Enrichment of LREE in rims compared to the cores of uraninite grains support the findings of Martz et al. (2019) suggesting that disruption of primary REE signatures is possible under certain fluid conditions. The greater stability and higher solubility of LREE-chloride species relative to HREE-chloride species (Migdisov et al., 2016) supports the preferentially leaching of LREE relative to HREE by Cl-rich fluids at the Kitts deposit.

The REE chondrite normalized patterns, the total REE contents and the U/Th ratios of uraninite of the Kitts deposit suggests a similar metasomatic fluid source for 
the Kitts-Post Hill belt to that of both the Domes region and Mistamisk deposit.

Uraninite from the Kitts deposit exhibits bell to pseudo-bell shaped REE patterns, with an increasing LREE/HREE ratio with increasing alteration / remobilization. The positive Eu anomalies of Group 2 uraninite may reflect metal leaching of plagioclase and/or amphibole rich rocks where by these minerals selectively remove Eu during crystallization, but release Eu when altered (Lottermoser, 1992), or remobilization by fluids with higher oxygen fugacity (Drake, 1975), supported by the late hematite mineralization (Hemmingway, 1990). 


\section{References}

Acosta-Góngora, P., Potter, E.G., Corriveau, L., Lawley, C.J.M., and Sparkes, G.W., 2018, Geochemistry of $\mathrm{U} \pm \mathrm{Cu} \pm \mathrm{Mo} \pm \mathrm{V}$ mineralization, Central Mineral Belt, Labrador: differentiating between mineralization styles using a principal component analysis approach; in Targeted Geoscience Initiative: 2018 report of activities, (ed.) N. Rogers; Geological Survey of Canada, Open File 8549, p. 381-391.

Alexandre, P. \& Kyser, T.K., 2005, Effects of cationic substitution and alteration in uraninite and implications for the dating of uranium deposits, Canadian Mineralogist, v. 43, p. 1005-1017.

Azimov, P.Y., Bushmin, S.A., 2007. Solubility of minerals and metasomatic rocks in hydrothermal solutions of varying acidity: thermodynamic modeling at $400-800$ ${ }^{\circ} \mathrm{C}$ and 1-5 kbar. Geochem. Int. 45, 1210-1234.

BHP, 2018, BHP Billiton Limited annual report 2018, 300 p. Available on: www.bhp.com/investor-centre.

Bowels, J., 2015, Age dating from electron microprobe analyses of U, Th, Ph: geological advantages and analytical difficulties, Microsc. Microanal, v. 21, p. 1114-1122.

Bruneton, P. 2014. "IAEA classification of uranium deposits." Vienna: IAEA.

Corriveau, L., and Mumin, A., 2010, Exploring for iron oxide copper-gold (Ag-Bi-Co-U) deposits: case examples, classification and exploration vectors, in Corriveau, L. and Mumin, A. eds., Exploring for iron oxide copper-gold deposits: Canada and 
global analogues, Geological Association of Canada, p. 89-110.

Corriveau, L., Williams, P., and Mumin, A., 2010, Alteration vectors to IOCG mineralization from uncharted terranes to deposits, in Corriveau, L. and Mumin, A. eds., Exploring for iron oxide copper-gold deposits: Canada and global analogues, Geological Association of Canada, p. 89-110.

Corriveau, L., Nadeau, O., Montreuil, J.-F., and Desrochers, J.-P., 2014, Report of activities for the Core Zone: Strategic geomapping and geoscience to assess the mineral potential of the Labrador Trough for multiple metals IOCG and affiliated deposits, Canada; Geological Survey of Canada, Open File 7714, 12 p. doi:10.4095/295529.

Corriveau, L., Montreuil, J.-F., and Potter, E.G., 2016, Alteration Facies Linkages Among Iron Oxide Copper-Gold, Iron Oxide-Apatite, and Affiliated Deposits in the Great Bear Magmatic Zone, Northwest Territories, Canada: Economic Geology, v. 111, p. 2045-2072, doi:10.2113/econgeo.111.8.2045.Cuney, M., 2009, The extreme diversity of uranium deposits: Mineralium Deposita, v. 44, p. 3-9, doi:

$10.1007 / \mathrm{s} 00126-008-0223-1$.

Cuney, M., Emetz, A., Mercadier, J., Mykchaylov, V., Shunko, V., and Yuslenko, A., 2012, Uranium deposits associated with Na-metasomatism from central Ukraine: A review of some of the major deposits and genetic constraints: Ore Geology Reviews, v. 44, p. 82-106, doi:10.1016/j.oregeorev.2011.09.007. 
Desrochers, J.P., 2016, Exploration Report (fall 2014 drill Program) on the Sagar Property, Romanet Horst, Labrador Trough, Québec, Canada, Energizer Resources Inc, p. 73.

Drake, M.J., 1975, The oxidation state of europium as an indicator of oxygen fugacity: Geochimica et Cosmochimica Acta, v. 39, p. 55-64, doi:10.1016/00167037(75)90184-2.

Eglinger, A., André-Mayer, A.-S., Vanderhaeghe, O., Mercadier, J., Cuney, M., Decrée, S., Feybesse, J.-L., and Milesi, J.-P., 2013, Geochemical signatures of uranium oxides in the Lufilian belt: From unconformity-related to syn-metamorphic uranium deposits during the Pan-African orogenic cycle: Ore Geology Reviews, v. 54, p. 197-213, doi:10.1016/j.oregeorev.2013.04.003.

Eglinger, A., Tarantola, A., Durand, C., Ferraina, C., Vanderhaeghe, O., André-Mayer, A.S., Paquette, J.-L., and Deloule, E., 2014, Uranium mobilization by fluids associated with $\mathrm{Ca}-\mathrm{Na}$ metasomatism: $\mathrm{A} \mathrm{P}-\mathrm{T}-\mathrm{t}$ record of fluid-rock interactions during Pan-African metamorphism (Western Zambian Copperbelt): Chemical Geology, v. 386, p. 218-237, doi:10.1016/j.chemgeo.2014.07.028.

Gabelman, J.W., 1988, Classification of uranium deposits: Ore Geology Reviews, v. 3, p. 13-29, doi: 10.1016/0169-1368(88)90014-5. 
Gale, A., Dalton, C.A., Langmuir, C.H., Su, Y., and Schilling, J-G. 2003, The mean composition of ocean ridge basalts. Geochemistry, Geophysics, Geosystems, v. 14: p. 489-518.

Gandhi, S., 1978, Geological setting and genetic aspects of uranium occurences in the Kaipokok Bay-Big River area, Labrador: Economic Geology, v. 73, p. 1492-1522.

Golder, H.Q.,1977, Feasibility study volume 2-geology and reserves and volume 6 geotechnical surveys for Kitts-Michelin project, Labrador, Newfoundland and Labrador Geological Survey, Assessment File LAB/0259, 583 pages.

Gower C.F., Flanagan, M.J., Kerr, A., and Bailet, D.G., 1982, Geology of the Kaipokok Bay - Big River area, Central Mineral Belt, Labrador, Newfoundland and Labrador Department of Mines and Energy, Mineral Development Division, Report 82-7.

Gower, C.F., Schärer, U., and Heaman, L.M., 1992, The Labradorian orogeny in the Grenville Province, eastern Labrador, Canada: Canadian Journal of Earth Sciences, v. 29, p. 1944-1957, doi:10.1139/e92-152.

Griffin, W.L., Powell, W.J., Pearson, N.J., and O'Reilly, S.Y., 2008, GLITTER: Data reduction software for laser ablation ICP-MS, in, Laser Ablation-ICP-Mass Spectrometry in the Earth Sciences: Current Practices and Outstanding Issues (Sylvester, P., Ed.), Mineralogical Association of Canada (MAC) Short Course Series, v. 40, p. 308-311. 
Groves, D.I., Bierlein, F.P., Meinert, L.D., and Hitzman, M.W., 2010, Iron Oxide CopperGold (IOCG) Deposits through Earth History: Implications for Origin, Lithospheric Setting, and Distinction from Other Epigenetic Iron Oxide Deposits: Economic Geology, v. 105, p. 641-654, doi:10.2113/gsecongeo.105.3.641.

Hertel, M., Podhorski-Thomas, M., Durston, K., Edwards, C. and Allard, S. 2009, Michelin uranium project, Labrador, Canada, NI 43-101 technical report on preliminary economic assessment. NI 43-101F1 Technical Report, 221 pages.

Hinchey, A., 2007, The Paleoproterozoic metavolcanic, metasedimentary and igneous rocks of the Aillik domain, Makkovik province, Labrador (NTS map area 130/03: Newfoundland and Labrador Department of Resources Geologic Survey Report, p. 25-44.

Hinchey, A.M. and Davis, W.J., 2013, New U-Pb zircon geochronology for the Measles Point Granite, Aillik Domain, Makkovik Province, Labrador (NTS map area 130/03). In Current Research. Government of Newfoundland and Labrador, Department of Natural Resources, Geological Survey, Report 13-1, p. 223-232.

Hitzman, M.W., Oreskes, N., and Einaudi, M.T., 1992, Geological characteristics and tectonic setting of proterozoic iron oxide (Cu-U-Au-REE) deposits: Precambrian Research, v. 58, p. 241-287, doi:10.1016/0301-9268(92)90121-4.

Hitzman, M.W., and Valenta, R.K., 2005, URANIUM IN IRON OXIDE-COPPER-GOLD (IOCG) SYSTEMS: Economic Geology, v. 100, p. 1657-1661, 
doi:10.2113/gsecongeo.100.8.1657.

IAEA. 2017, How China has Become the World's Fastest Expanding Nuclear Power Producer. https://www.iaea.org/newscenter/news/how-china-has-become-theworlds-fastest-expanding-nuclear-power-producer.

IAEA. 2016, IAEA Sees Global Nuclear Power Capacity Growing Through 2030. https://www.iaea.org/newscenter/pressreleases/iaea-sees-global-nuclearpower-capacity-growing-through-2030.

Jackson, S.E., 2008, Calibration strategies for elemental analysis by LA-ICP-MS, in, Laser Ablation-ICP-Mass Spectrometry in the Earth Sciences: Current Practices and Outstanding Issues (Sylvester, P., Ed.), Mineralogical Association of Canada (MAC) Short Course Series, v. 40, p. 169-188.

Jackson, S.E., 2008, LAMTRACE data reduction software for LA-ICP-MS, in, Laser Ablation-ICP-Mass Spectrometry in the Earth Sciences: Current Practices and Outstanding Issues (Sylvester, P., Ed.), Mineralogical Association of Canada (MAC) Short Course Series, v. 40, p. 305-307.

Keleman, P.B., Hanghøj, K., and Greene, A.R. 2014, One view of the geochemistry of subduction-related magmatic arcs, with an emphasis on primitive andesite and lower crust. In Treatise on geochemistry, second edition, volume 4, The Crust. Edited by R.L. Rudnick, H.D. Holland and K.K. Turekian. Elsevier, Amsterdam, p. 749-806. 
Kemp, A.J., and Hawkesworth, C.J. 2005, Granitic perspectives on the generation and secular evolution of the continental crust. In Treatise on geochemistry, volume 3, The Crust. Edited by R.L. Rudnick, H.D. Holland and K.K. Turekian. Elsevier, Amsterdam, p. 349-410.

Keppler, H., Wyllie, P.J., 1991. Partitioning of $\mathrm{Cu}, \mathrm{Sn}, \mathrm{Mo}, \mathrm{W}, \mathrm{U}$, and Th between melt and aqueous fluid in the systems haplogranite- $\mathrm{H} 2 \mathrm{O}-\mathrm{HCl}$ and haplogranite- $\mathrm{H} 2 \mathrm{O}-\mathrm{HF}$. Contrib. Mineral. Petrol. 109, 139-150.

Kerr, A., Ryan, B., Gower, C., and Wardle, R., 1996, The Makkovik province: extensions of the Ketilidian Mobile Belt in mainland North America, in Brewer, T. ed., Precambrian crustal evolution In the North Atlantic region, Geological Society of Canada, v. 112.

Kerr, A., and Sparkes, G., 2008, Diverse styles of uranium mineralization in the Central Mineral Belt of Labrador: an overview and preliminary discussion: Newfoundland and Labrador Department of Resources Geologic Survey Report 08-1.

Ketchum, J.W.F., Barr, S.M., Culshaw, N.G., and White, C.E., 2001, U-Pb ages of granitoid rocks in the northwestern Makkovik Province, Labrador: evidence for 175 million years of episodic synorogenic and postorogenic plutonism: Canadian Journal of Earth Sciences, v. 38, p. 359-372, doi: 10.1139/cjes-38-3-359.

Ketchum, J., Culshaw, N.G., and Barr, S.M., 2002, Anatomy and orogenic history of a Paleoproterozoic accretionary belt: the Makkovik Province, Labrador, Canada: 
Canadian Journal of Earth Sciences, v. 34, p. 1072-1088.

Kontonikas-Charos, A., Ciobanu, C.L., Cook, N., 2014, Albitization and redistribution of REE and Y in IOCG systems: Insights from Moonta-Wallaroo, Yorke Peninsula, South Australia: Lithos, v. 208-209, p. 178-201.

Lach, P., Mercadier, J., Dubessy, J., Boiron, M.-C., Cuney, M., 2013, In Situ Quantitative Measurement of Rare Earth Elements in Uranium Oxides by Laser AblationInductively Coupled Plasma-Mass Spectrometry: Geostandards and Geoanalytical Research, v. 37, p. 277-296.

Lawley, C.J.M., Creaser, R.A., Jackson, S.E., Yang, Z., Davis, B.J., Pehrsson, S.J., Dubé, B., Mercier-Langevin, P., and Vaillancourt, D., 2015, Unraveling the Western Churchill Province Paleoproterozoic Gold Metallotect: Constraints from Re-Os Arsenopyrite and U-Pb Xenotime Geochronology and LA-ICP-MS Arsenopyrite Trace Element Chemistry at the BIF-Hosted Meliadine Gold District, Nunavut, Canada: Economic Geology, v. 110, p. 1425-1454, doi:10.2113/econgeo.110.6.1425.

Lottermoser, B.G., 1992, Rare earth elements and hydrothermal ore formation processes: Ore Geology Reviews, v. 7, p. 25-41, doi:10.1016/01691368(92)90017-F.

Ludwig, K.R., 2003, User's manual for Isoplot/Ex rev. 3.00: a Geochronological Toolkit for Microsoft Excel. Special Publication, 4, Berkeley Geochronology Center, Berkeley, 
$70 \mathrm{p}$.

Marten, B., 1977, The relationship between the Aillik Group and the Hopedale gneiss, Kaipokok Bay, Labrador: Memorial University of Newfoundland.

McDonough, W., and Sun, S., 1995, The composition of the Earth: Chemical Geology, v. 120, p. 223-253.

Meneghel, L., 1981, The occurrence of uranium in the Katanga System of northwestern Zambia: Economic Geology, v. 76, p. 56-68, doi:10.2113/gsecongeo.76.1.56.

Mercadier, J., Cuney, M., Lach, P., Boiron, M.-C., Bonhoure, J., Richard, A., Leisen, M., and Kister, P., 2011, Origin of uranium deposits revealed by their rare earth element signature: Origin of $U$ deposits revealed by the rare earth elements: Terra Nova, v. 23, p. 264-269, doi:10.1111/j.1365-3121.2011.01008.x.

Migdisov, A.A.,Williams-Jones, A.E.,Wagner, T., 2009. An experimental study of the solubility and speciation of the Rare Earth Elements (III) in fluoride- and chloridebearing aqueous solutions at temperatures up to $300^{\circ} \mathrm{C}$. Geochim. Cosmochim. Acta 73, 7087-7109.

Migdisov, A.A., Williams-Jones, A.E., van Hinsberg, V., Salvi, S., 2011. An experimental study of the solubility of baddeleyite $(\mathrm{ZrO} 2)$ in fluoride-bearing solutions at elevated temperature. Geochim. Cosmochim. Acta 75, 7426-7434

Migdisov, A., Williams-Jones, A., Brugger, J., and Caporuscio, F., 2016, Hydrothermal 
transport, deposition, and fractionation of the REE: Experimental data and thermodynamic calculations, Chemical Geology, v. 439. p. 13-42. 10.1016/j.chemgeo.2016.06.005.

Montreuil, J., Corriveau, L., and Potter, E., 2015, Formation of albitite-hosted uranium within IOCG systems: the Southern Breccia, Great Bear magmatic zone, Northwest Territories, Canada: Mineralium Deposita, p. 293-325.

Montreuil, J., Potter, E., and De Toni, A., 2016, On the relationship between alteration facies and metal endowment of iron oxide-alkali-altered, Sothern Great Bear Magmatic zone, Canada: Economic Geology, v. 111, p. 2139-2168.

Morrison, E. R., 1956, Report on prospecting in area D, Labrador. Newfoundland and Labrador Geological Survey, Assessment File LAB/0182.

Nunn G., A. G., Thomas, A., and Kroght, E., 1985, The Labradorian orogeny: geochronological database, Current research for 1984, Newfoundland Department of Mines and Energy, Mineral Development Division, Report 85-1, p. $43-54$

OECD, 2018, Uranium 2018: Resources, Production and Demand, NEA no. 7413.

Ootes, L., Goff, S., Jackson, V.A., Gleeson, S.A., Creaser, R.A., Samson, I.M., Evensen, N., Corriveau, L., and Mumin, A.H., 2010, Timing and thermochemical constraints on multi-element mineralisation at the Nori/RA Cu-Mo-U prospect, Great Bear magmatic zone, Northwest Territories, Canada: Mineralium Deposita, v. 45, p. 
549-566, doi:10.1007/s00126-010-0291-x.

Pearce, J.A., Harris, N.B.W., and Tindle, A.G. 1984, Trace element determination diagrams for the tectonic interpretation of granitic rocks. Journal of Petrology, v. 25: p. 956-983.

Porter, T.M., 2010, Current understanding of iron oxide associated-alkali altered mineralised systems: Part 1-An overview; Part 2-A review. In: Porter, T.M. (Ed.), Hydrothermal Iron Oxide Copper-Gold and Related Deposits: A Global Perspective Advances in the Understanding of IOCG Deposits volume 3. Porter Geoscience Consultant Publication, Adelaide, p. 5-106.

Polito, P.A., Kyser, K.T., Stanley, C., 2009, The Proterozoic, albitite-hosted, Valhalla uranium deposit, Queensland, Australia, a description of the alteration assemblage associated with uranium mineralisation in diamond drill hole V39. Miner. Deposita v. 44, p. 11-40.

Porto de Silveira, C.L., Shorscher, H.D., Miekeley, N., 1991, The geochemistry of albitisation and related uranium mineralisation, Espinharas, Paraiba, Brazil. J. Geochem. Explor, v. 40, p. 329-347.

Potter, E.G., Corriveau, L., Montreuil, J.-F., Yang, Z., Comeau, J.-S., 2014, Geochemical signatures of uraninite from iron oxide-copper-gold (IOCG) systems of the Great Bear magmatic zone, Canada. Geol. Surv. Can Open File 7545, 1 sheet.

Potter, E.G., Montreuil, J.-F., Corriveau, L., Davis, W.J., 2019, The Southern Breccia 
Metasomatic Uranium System of the Great Bear Magmatic Zone, Canada: Iron Oxide-Copper-Gold (IOCG) and Albitite-Hosted Uranium Linkages. In Ore Deposits: Origin, Exploration, and Exploitation, edited by S. Decrée, L. Robb, eds., American Geophysical Union, Geophysical Monograph 242, First Edition, p. 109130.

Potter, E.G., Acosta-Gongora, P., Corriveau, L., Montreuil, J-F., and Yang, Z., accepted, Uranium enrichment in iron oxide and alkali-altered (IOAA) systems of the Great Bear magmatic zone as revealed by trace element signatures of uraninite, in Corriveau, L., Mumin, A.H., Potter, E.G., eds, Iron oxide-copper-gold and affiliated deposits: GAC special paper 52.

Putnis, A., 2009, Mineral Replacement Reactions: Reviews in Mineralogy and Geochemistry, v. 70, p. 87-124, doi: 10.2138/rmg.2009.70.3.

Romberger, S.B., 1984. Transport and deposition of uranium in hydrothermal systems at temperatures up to $300^{\circ} \mathrm{C}$ : geological implications. In: DeVivo, B., Ippolito, F., Capaldi, G., Simpson, P.R. (Eds.), Uranium Geochemistry, Mineralogy, Geology, Exploration and Resources. Institution of Mining and Metallurgy, London, pp. $12-17$.

Rudnick, R.L., and Gao, S. 2014, Composition of the Continental Crust. In Treatise on geochemistry, second edition, volume 4, the crust. Edited by R.L. Rudnick, H.D. Holland and K.K. Turekian. Elsevier, Amsterdam, p. 1-64. 
Ryan, B. 1984, Regional geology of the central part of the Central Mineral Belt, Labrador. Government of Newfoundland and Labrador, Department of Mines and Energy, Mineral Development Division, Memoir 3, p. 185.

Salvi, S., Fontan, F., Monchoux, P., Williams-Jones, A.E., Moine, B., 2000. Hydrothermal mobilization of high field strength elements in alkaline igneous systems: evidence from the Tamazeght Complex (Morocco). Econ. Geol. 95, 559-576.

Schärer, U., Krogh, T.E., Wardle, R.J., Ryan, B., and Gandhi, S.S., 1988, U-Pb ages of early and middle Proterozoic volcanism and metamorphism in the Makkovik Orogen, Labrador: Canadian Journal of Earth Sciences, v. 25, p. 1098-1107, doi:10.1139/e88-107.

Skirrow, R., 2010, “Hematite-group” IOCG \pm U ore systems: Tectonic settings, hydrothermal characteristics, and $\mathrm{Cu}-\mathrm{Au}$ and $\mathrm{U}$ mineralizing processes: Geological Association of Canada, Short Course Notes 20, p. 39-58.

Sparkes, G., 2017, Uranium mineralization within the Central Mineral Belt of Labrador: a summary of the diverse styles, settings and timing of mineralization: Newfoundland and Labrador Department of Resources Open File LAB/1684.

Sparkes, G., and Dunning, G., 2015, New U-Pb age constraints on the development of uranium mineralization within the Central Mineral Belt of Labrador: Newfoundland and Labrador Department of Resources Geologic Survey Report 15-1, p. 105-113. 
Sparkes, G., Dunning, G., Fonkwe, M., and Langille, A., 2016, Age constraints on the formation of the iron oxide-rich hydrothermal breccias of the Moran Lake area: evidence for potential IOCG-style mineralization within the Central Mineral Belt of Labrador: Newfoundland and Labrador Department of Resources Geologic Survey Report 16-1.

Sparkes, G.W., Dunning, G.R., Langille, A, 2017, The Michelin deposit: an example of albitite-hosted uranium mineralization within the Central Mineral Belt of Labrador. Newfoundland and Labrador Department of Natural Resources Geological Survey, Report 17-1, p. 219-238.

Timofeev, A., Migdisov, A.A., Williams-Jones, A.E., Roback, R., Nelson, A.T., and Xu, H., 2018, Uranium transport in acidic brines under reducing conditions: Nature Communications, v. 9, doi:10.1038/s41467-018-03564-7.

Tracey, M., 2009, Study of Volcanic and Sediment-Hosted Uranium within the Post Hill Group, Central Mineral Belt Region, Labrador [B.Sc.]: Memorial University of Newfoundland, $137 \mathrm{p}$.

Wardle, R.J. \& Ryan, B and Nunn, G.A.G. \& Mengel, F.C., 1990, Labrador segment of the Trans-Hudson Orogen: crustal development through oblique convergence and collision, v. 37, p. 353-369.

Wilde. A., 2013, Towards a model for albitite-type uranium, Miner 3, p. 36-48.

Wilton, D.H.C., and Wardle, R.J., 1987, Two contrasting metallogenic styles in the Early 
Proterozoic Upper Aillik Group, Central Mineral Belt, Labrador, Canada:

Mineralium Deposita, v. 22, doi:10.1007/BF00206610.

Wilton, D.H.C., and Longerich, H.P., 1993, Metallogenic significance of trace element and $\mathrm{U}-\mathrm{Pb}$ isotope data for uraninite-rich mineral separates from the Labrador Central Mineral Belt: Canadian Journal of Earth Sciences, v. 30, p. 2352-2365, doi:10.1139/e93-204.

Wood, S.A., 2005.The aqueous geochemistry of zirconium, hafnium, niobium and tantalum, In: Rare-Element Geochemistry and Mineral Deposits, R. L. Linnen and I. M. Samson (Editors). Geological Association of Canada Short Course Notes 17, Geological Association of Canada, p. 217-250. 


\subsection{Magnetite geochemistry of the Kitts-Post Hill belt of the Central Mineral Belt,}

\section{Labrador}

\subsection{Methods}

\subsubsection{Rock collection and mineral identification}

Samples were collected from the Newfoundland and Labrador Geological Survey's core storage facility in St. John's, Newfoundland and from the Goose Bay Core Storage Library in Goose Bay, Labrador. Additional samples were collected from the Sunil S. Gandhi collection housed at the Geological Survey of Canada. Mineral identification and elaboration of paragenetic relationships was done by carrying out detailed petrographic studies complemented with the use of scanning electron microscope (SEM)

A Zeiss EVO 50 series SEM was used to describe the mineralogy of polished thin section samples at the Geological Survey of Canada in Ottawa, Ontario. This system includes a backscattered electron detector (BSD), Everhart-Thornley secondary electron detector (SE), a variable pressure secondary electron detector (VPSE) and a cathodoluminescence detector $(\mathrm{CL})$. The Oxford energy dispersive spectrometry (EDS) system includes the X-MAX 150 silicon drift detector, with INCA Energy 450 software and AZtec Energy 3.1 microanalysis software. The SEM operating conditions were as follows: standard working distance of $8.5 \mathrm{~mm}$; voltage set at $20 \mathrm{kV}$, with a probe current of $400 p A$ to $1 \mathrm{nA}$; and filament current set to $2^{\text {nd }}$ peak. Images of the samples were acquired using the back scattered electron (BSE) mode. The INCA mineral liberation 
analysis software was used to find and identify minerals based on chemical composition from the EDS.

\subsubsection{In-situ LA-ICP-MS element mapping}

Sample 18-CD-16 from the Inda deposit and sample 18-CD-10 from the Gear deposit were chosen for LA-ICP-MS element mapping. Element mapping of magnetite was carried out on selected areas of thin and/or thick sections ( $200 \mu \mathrm{m})$ by laser ablation inductively coupled plasma mass spectrometry (LA-ICP-MS) at the Geological Survey of Canada, using a Photon Machines Analyte G2 193 nm excimer laser ablation system, with a Helex II ablation cell, coupled to an Agilent 7700x quadrupole ICP-MS. The mapping procedure closely follows the method of Lawley et al. (2015; under review). Element maps were constructed by rastering a focused laser beam across the sample surface to form a series of line scans. Laser conditions during the analytical sessions include a fluence of $4.3-4.9 \mathrm{~J} / \mathrm{cm}^{2}$, a repetition rate of $30 \mathrm{~Hz}$, a spot size of $5 \mu \mathrm{m}$ and a scan speed of $5 \mu \mathrm{m} / \mathrm{s}$. Prior to each ablation pass, the sample surface was cleaned by rastering the laser across the sample at a rate of 2-3 pulses every $5 \mu \mathrm{m}$. The cleaning step was followed by 50-60 s of washout, then each analysis began with $20 \mathrm{~s}$ of background measurement (gas blank). The ablation aerosol was transported out of the Helix II cell using $1 \mathrm{~L} / \mathrm{min}$ of helium gas, and was subsequently mixed with $1 \mathrm{~L} / \mathrm{min}$ of argon gas before entering the ICP-MS. The ICP-MS was tuned on NIST-612 to achieve $>9,000 \mathrm{cps} / \mathrm{ppm}$ on $\mathrm{Lu}\left(50 \mu \mathrm{m}\right.$ spot, $\sim 7 \mathrm{~J} / \mathrm{cm}^{2}$ at $\left.10 \mathrm{~Hz}\right)$, while minimizing the production of oxides ( $<0.2 \%$ for ThO/Th) and maintaining a U/Th ratio of $\sim 1.0$. The total duty cycle time to measure all masses on the ICP-MS (in time-resolved analysis mode) was $250 \mathrm{~ms}$. 
Utilizing these settings, every $1 \mathrm{~s}$ of analysis or the equivalent of a $5 \mu \mathrm{m}$ spot diameter, included four full scans of the mass spectrometer.

The calibration procedures of Jackson (2008) were followed during the mapping sessions. Standardization was achieved by calibrating the signals of unknowns against analyses of GSE-1G (for most major and trace elements), and internal reference materials pyrrhotite (sulphur calibration) and calcite (carbon calibration), and normalizing total element (or element oxide) concentrations to $100 \%$. Reference materials were analyzed every 20 unknowns to account for instrument drift during the mapping run. Secondary standards GSD-1G, NIST-160 or BC-28 (UQAC) were analyzed throughout the mapping sessions, and routinely yielded calculated concentrations within $5-10 \%$ of the accepted values for most elements. Reference values for GSE-1G, GSE-1G and NIST-610 are taken from the online geological and environmental reference materials database (GeoReM; Jochum et al., 2005). The software programs LAMTRACE and PixeLAte (Jackson, 2008) were used to calibrate the data and convert the line scans to elemental maps. Elements analyzed include: $\mathrm{Na}, \mathrm{Mg}, \mathrm{Al}, \mathrm{Si}, \mathrm{P}, \mathrm{S}, \mathrm{K}, \mathrm{Ca}, \mathrm{Ti}, \mathrm{V}, \mathrm{Cr}, \mathrm{Mn}$, $\mathrm{Fe}, \mathrm{Co}, \mathrm{Ni}, \mathrm{Cu}, \mathrm{Zn}, \mathrm{As}, \mathrm{Sr}, \mathrm{Y}, \mathrm{Zr}, \mathrm{Nb}, \mathrm{Mo}, \mathrm{Sn}, \mathrm{Ba}, \mathrm{La}, \mathrm{Ce}, \mathrm{Pr}, \mathrm{Nd}, \mathrm{Sm}, \mathrm{Eu}, \mathrm{Gd}, \mathrm{Tb}, \mathrm{Dy}, \mathrm{Ho}, \mathrm{Er}$, Tm, Yb, Lu, Hf, Ta, W, Tl, ${ }^{206} \mathrm{~Pb},{ }^{207} \mathrm{~Pb},{ }^{208} \mathrm{~Pb}, \mathrm{Bi}, \mathrm{Th},{ }^{235} \mathrm{U}$, and ${ }^{238} \mathrm{U}$.

\subsection{Results}

\subsubsection{Petrography}

Magnetite grains in sample 18-CD-10 of the Gear deposit (Fig. 3-1a) are coarsegrained ( $<150 \mathrm{um}$ ) and form bands (alternating with lamellae of amphibole, albite and \pm 
quartz) within the sample. Minor amounts of apatite occur in veinlets; minor uraninite is disseminated or occurs in veinlets within the magnetite lamellae. Two generations of magnetite have been identified, an early coarser-grained, unaltered magnetite, and a later, finer-grained magnetite/hematite forming around the margins/fractures of early magnetite

Magnetite grains in sample 18-CD-16 of the Inda deposit (Fig. 3-1b) are finegrained ( $<75 \mathrm{um})$ and are disseminated within a matrix of fine-grained amphibole and albite. The matrix is also composed of minor fine-grained disseminated calcite, titanite and uraninite
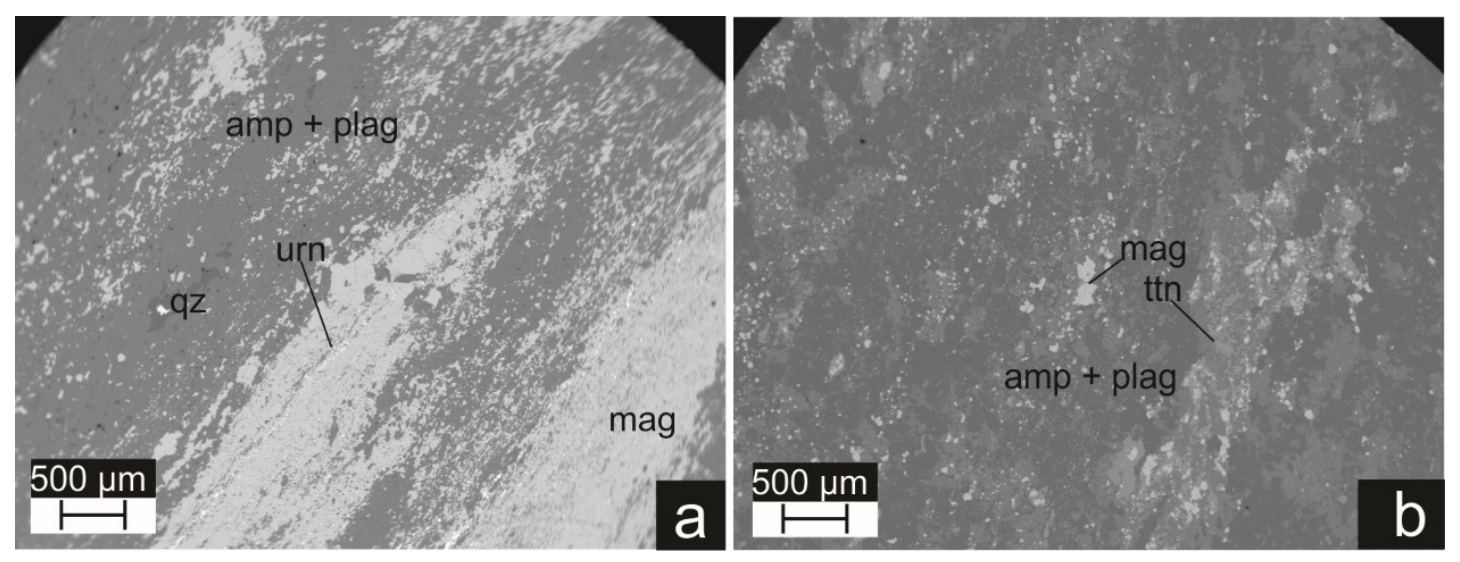

Fig. 3-1: BSE image of (a) alternating lamellae of fine-grained amphibole and plagioclase with minor quartz and magnetite with disseminated uraninite; Sample 18-CD-10 of the Inda deposit. (b) Fine grained matrix of amphibole and plagioclase with disseminated magnetite and titanite; Sample 18-CD-16 of the Gear deposit. Abbreviations: amphibole (amp), magnetite (mag), plagioclase (plag), quartz (qz), titanite (ttn) and uraninite (urn) 


\subsubsection{Geochemistry}

The magnetite data were filtered based on the following criteria to confirm the analyses from the LA-ICP-MS mapping were of magnetite, and also to avoid significant alteration: Fe $>500000$ ppm; S $<25000$ ppm; Si, Ca and $\mathrm{Al}<10000$ ppm.

The magnetite in sample $18-\mathrm{CD}-10$ is characterized by very high $\mathrm{V}$ contents between 1 and 9 wt \% and a median of 3.6 wt \%, high Zn contents between 50 and 21000 ppm and a median of 956 ppm, low Cu contents between 1 and 5800 ppm and a median of $1.75 \mathrm{ppm}$ and low Sn contents between 0.3 and $11 \mathrm{ppm}$ and a median of 0.92 ppm (Fig. 3-2, Table 3-1).

The magnetite in sample 18-CD-16 is characterized by high $V$ contents between 1 and 3 wt \% and a median of 1.83 wt \%, low Ni between 1.28 and 158 ppm and a median of $34.3 \mathrm{ppm}$ and low Cr contents between 5.34 and $133 \mathrm{ppm}$ and a median of $5.34 \mathrm{ppm}$, low Cu contents with a median of 1.76 ppm ( $\max 87000$ ppm) and low Sn contents between 0.3 and 7 ppm and a median of 0.3 ppm (Fig. 3-2, Table 3-1).

Although the samples were homogeneous (on the grain-scale), with no zoning observed in the element maps, both samples are characterized by highly variable $Y$ (0.0001-1), $\mathrm{Pb}(0.001-5000), \operatorname{Zr}(0.0001-100)$, and $\mathrm{Hf}(0.01-100)$ when normalized to bulk continental crust (BCC; Fig. 3-3). Sample 18-CD-10 is also characterized by variable $\mathrm{Nb}(0.0001-10)$ and $\mathrm{Mg}(0.0001-1)$, while sample $18-\mathrm{CD}-16$ has variable $\mathrm{Cu}(0.1-10000)$, Ti (0.0001-1) and Zn (0.01-1000). 


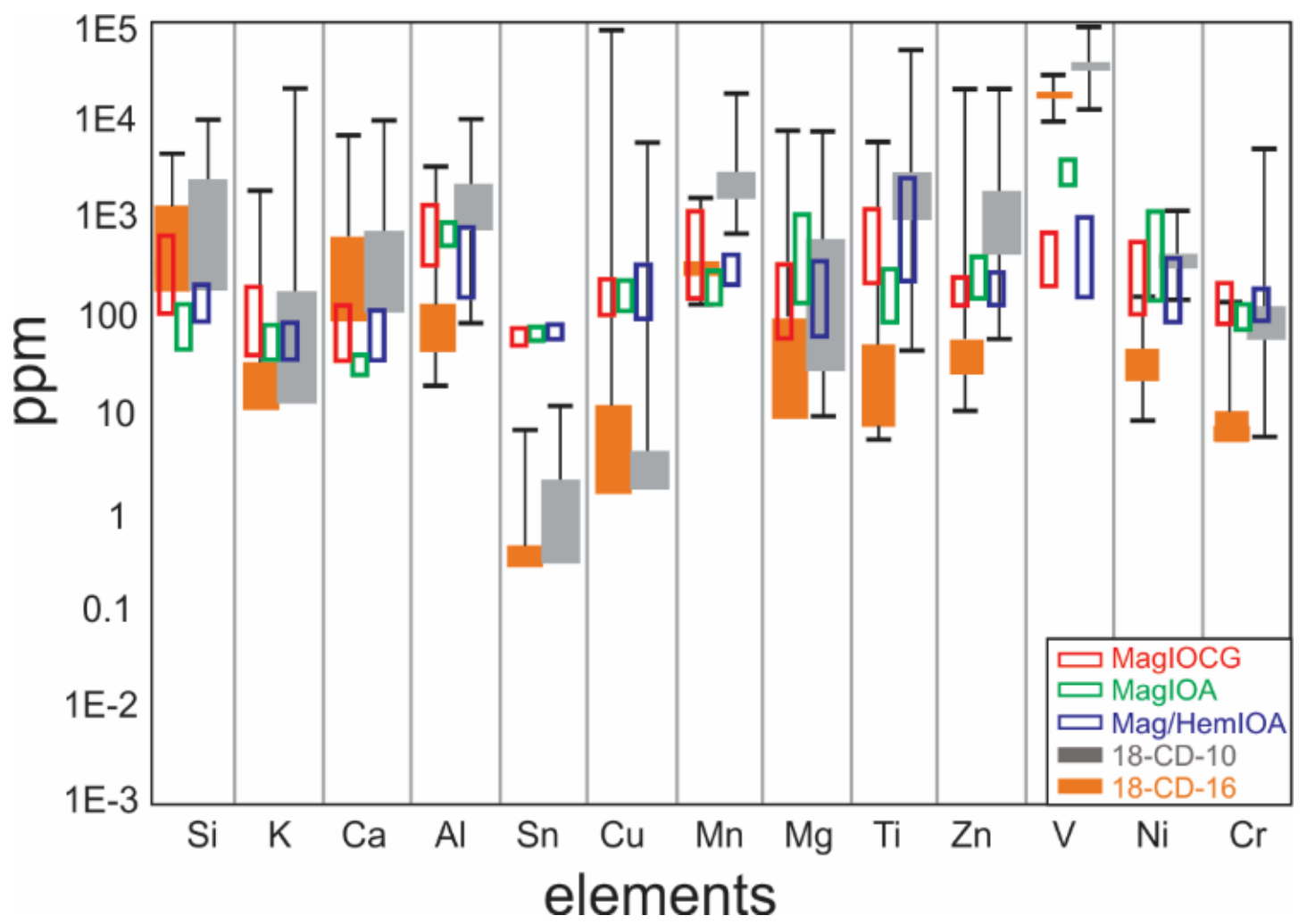

Fig. 3-2: Minor to trace element box (in ppm) and whisker plot of magnetite from this study plotted alongside representative IOAA data from Huang et al. (2019). 

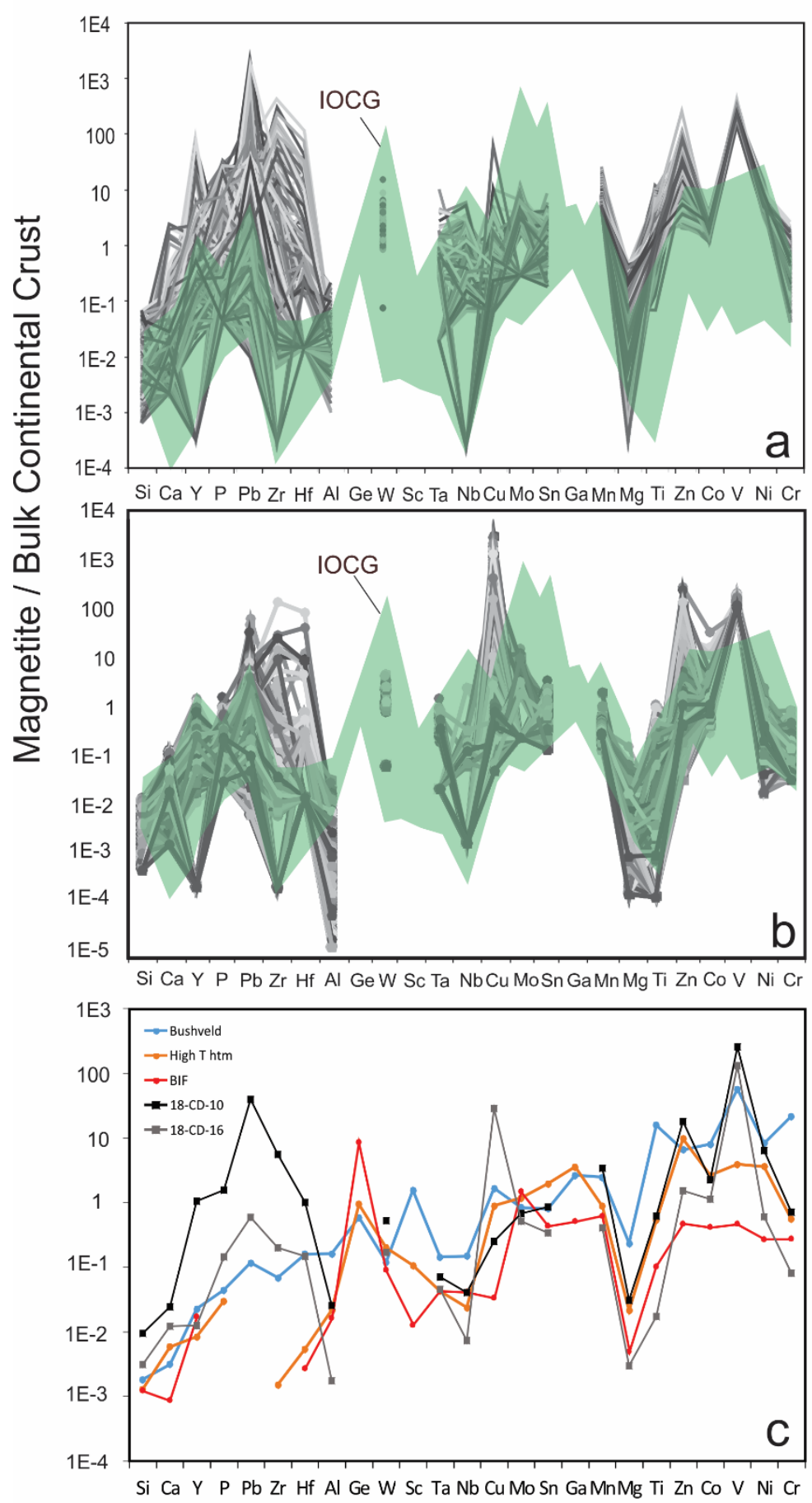

Fig. 3-3: Magnetite trace element plot normalized to bulk continental crust (BCC) (Rudnick and Gao, 2003). Average trace element data for magnetite of high temperature hydrothermal deposits (high t htm), the Bushveld deposit (Fe-Ti-P type) and Banded Iron Formation deposit (Dare et al., 2014) and IOCG-type deposits (in green) (Huang et al., 2019) are also plotted. (a) Sample 18-CD-10 ( $n=1000)$ of the Gear deposit. (b) Sample 18-CD-16 ( $n=1749$ ) of the Inda deposit, and (c) Average trace of both samples 
Table 3-1: LA-ICP-MS data (ppm) of magnetite used to create Fig. 3-2. Abbreviations: minimum (min); first quartile (Q1); median (med); third quartile (Q3); maximum (max)

\begin{tabular}{|c|c|c|c|c|c|c|c|c|c|c|c|c|c|c|}
\hline & & Si & K & $\mathrm{Ca}$ & Al & Sn & $\mathrm{Cu}$ & $M n$ & $\mathrm{Mg}$ & $\mathrm{Ti}$ & $\mathrm{Zn}$ & $\mathbf{v}$ & $\mathrm{Ni}$ & $\mathrm{Cr}$ \\
\hline \multirow{10}{*}{ 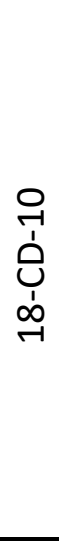 } & Min & 185 & 12.9 & 104 & 85.7 & 0.312 & 1.75 & 674 & 9.20 & 0.004 & 58.6 & 12298 & 140 & 5.57 \\
\hline & Q1 & 185 & 12.9 & 104 & 798 & 0.312 & 1.75 & 1601 & 27.7 & 0.099 & 449 & 33895 & 324 & 60.2 \\
\hline & Med & 950 & 51.9 & 163 & 1315 & 0.923 & 1.75 & 2059.2 & 143 & 0.158 & 956 & 35885 & 368 & 91.4 \\
\hline & Q3 & 2510 & 176 & 735 & 2204 & 2.07 & 4.10 & 2867 & 601 & 0.283 & 1856 & 38070 & 417 & 125 \\
\hline & Max & 9992 & 20827 & 9944 & 9843 & 11.7 & 5847 & 18900 & 7570 & 5.16 & 21162 & 90014 & 1132 & 5029 \\
\hline & Q1-min & 0.000 & 0.000 & 0.000 & 712 & 0.000 & 0.00 & 927 & 18.5 & 0.095 & 390 & 21597 & 184 & 54.6 \\
\hline & Q1 & 185 & 12.9 & 104 & 798 & 0.312 & 1.75 & 1601 & 27.7 & 0.099 & 449 & 33895 & 324 & 60.2 \\
\hline & med-Q1 & 765 & 39.0 & 59.3 & 518 & 0.611 & 0.00 & 458 & 115 & 0.059 & 507 & 1990 & 43.7 & 31.2 \\
\hline & Q3-med & 1560 & 124 & 572 & 889 & 1.15 & 2.35 & 808 & 459 & 0.125 & 900 & 2185 & 48.9 & 33.8 \\
\hline & Max-Q3 & 7482 & 20651 & 9209 & 7639 & 9.60 & 5843 & 16034 & 6968 & 4.88 & 19305 & 51944 & 715 & 4904 \\
\hline \multirow{10}{*}{ 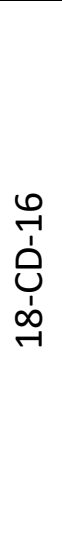 } & Min & 176 & 12.0 & 91.3 & 1.48 & 0.280 & 1.59 & 115 & 8.88 & 0.881 & 2.75 & 8225 & 1.28 & 5.34 \\
\hline & Q1 & 176 & 12.0 & 91.3 & 42.7 & 0.280 & 1.59 & 261 & 8.88 & 7.81 & 25.6 & 17079 & 22.5 & 5.34 \\
\hline & Med & 312 & 12.0 & 119 & 76.0 & 0.280 & 1.76 & 304 & 26.0 & 24.8 & 39.2 & 18281 & 34.3 & 5.34 \\
\hline & Q3 & 1321 & 33.6 & 631 & 134 & 0.454 & 12.2 & 349 & 96.3 & 51.6 & 56.8 & 19460 & 46.7 & 10.6 \\
\hline & Max & 4569 & 1913 & 7059 & 3288 & 6.58 & 87088 & 1565 & 7802 & 6008 & 20801 & 28960 & 158 & 133 \\
\hline & Q1-min & 0.000 & 0.000 & 0.000 & 41.2 & 0.000 & 0.000 & 146 & 0.000 & 6.93 & 22.85 & 8855 & 21.2 & 0.000 \\
\hline & Q1 & 176 & 12.0 & 91.3 & 42.7 & 0.280 & 1.59 & 261 & 8.88 & 7.81 & 25.6 & 17079 & 22.5 & 5.34 \\
\hline & med-Q1 & 135 & 0.000 & 28.2 & 33.4 & 0.000 & 0.172 & 43.0 & 17.2 & 17.0 & 13.6 & 1201 & 11.9 & 0.000 \\
\hline & Q3-med & 1010 & 21.6 & 511 & 57.8 & 0.174 & 10.5 & 44.6 & 70.2 & 26.8 & 17.6 & 1180 & 12.4 & 5.23 \\
\hline & Max Q3 & 3248 & 1879 & 6428 & 3154 & 6.13 & 87075 & 1216 & 7706 & 5956 & 20744 & 9499 & 111 & 123 \\
\hline
\end{tabular}




\subsubsection{LA-ICP-MS Element Maps}

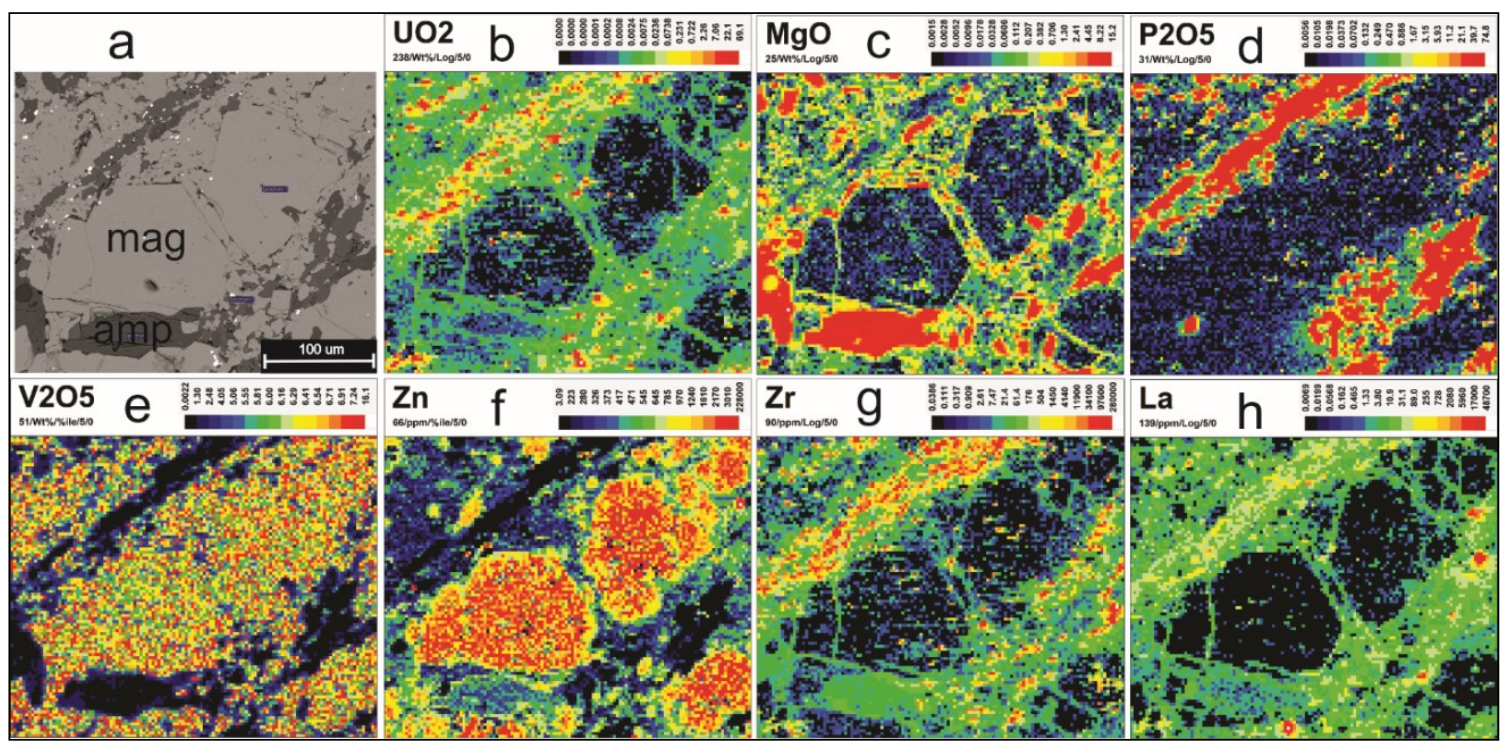

Fig. 3-4: (a) BSE image and (b-h) LA-ICP-MS element maps of sample CD-18-10 containing coarse-grained magnetite in bands rimmed by magnetite and hematite, associated with amphibole and apatite.

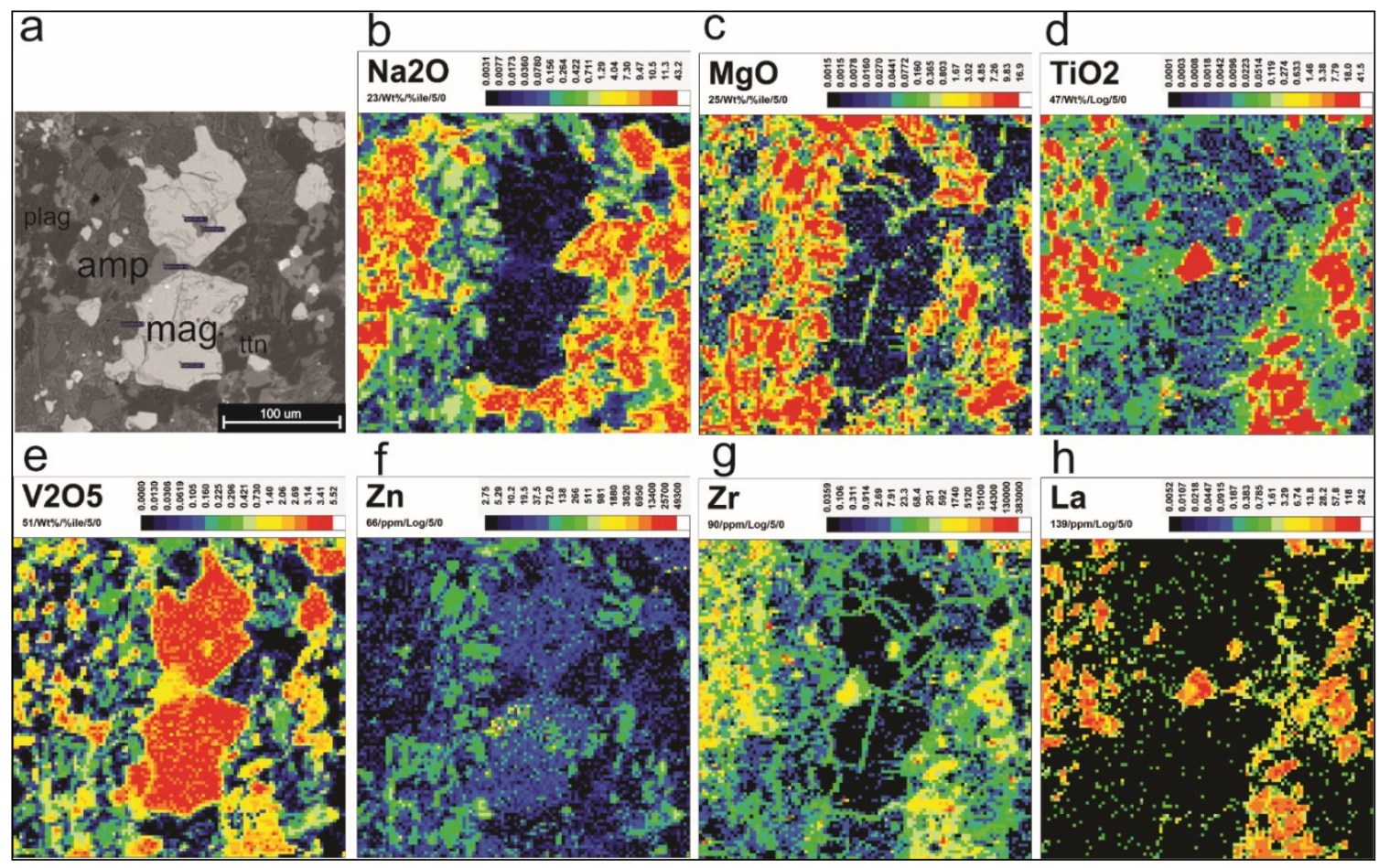

Fig. 3-5: (a) BSE image and (b-h) LA-ICP-MS element maps of samples CD-18-16 containing fine-grained magnetite within a plagioclase and amphibole matrix. 
Two generations of magnetite in sample 18-CD-10 have been identified, an early coarser-grained, unaltered magnetite, and a later, finer-grained magnetite/hematite forming around the margins/fractures of early magnetite enriched in $\mathrm{U}, \mathrm{REE}$ and $\mathrm{Mg}$ (Fig. 3-4b,c,h) but depleted in Zn (Fig. 3-4f). The apatite rich vein-like structure that hosts small grains of uraninite exhibits an enrichment in $\mathrm{Zr}$ (Fig. 3-4g). Sample 18-CD-16 is characterized by a single generation of magnetite. The $\mathrm{Zr}$ and $\mathrm{Mg}$ enrichment visible along fractures is similar to the surrounding amphibole (Fig. 3-5c,g). Titanite is enriched in REE relative to magnetite (Fig. $3-5 d, h$ ).

\subsection{Discussion}

Magnetite that was analyzed by LA-ICP-MS is interpreted to be of at least two different generations based on geochemistry and petrography. Using the Dare et al. (2014) discrimination plot, $\mathrm{Ni} / \mathrm{Cr}$ ratios distinguishes hydrothermal from magmatic magnetite (Fig. 3-6). According to this plot, magnetite from sample 18-CD-10 is strictly hydrothermal in origin, while magnetite from sample 18-CD-16 straddles the magmatic/hydrothermal distinction line. Both samples are enriched in V and in Fig. 3-7 plot strictly in the magmatic Fe-Ti-V deposit field. This slightly contradicts the hydrothermal origin defined by the $\mathrm{Ni} / \mathrm{Cr}$ ratios (Dare et al., 2014). 


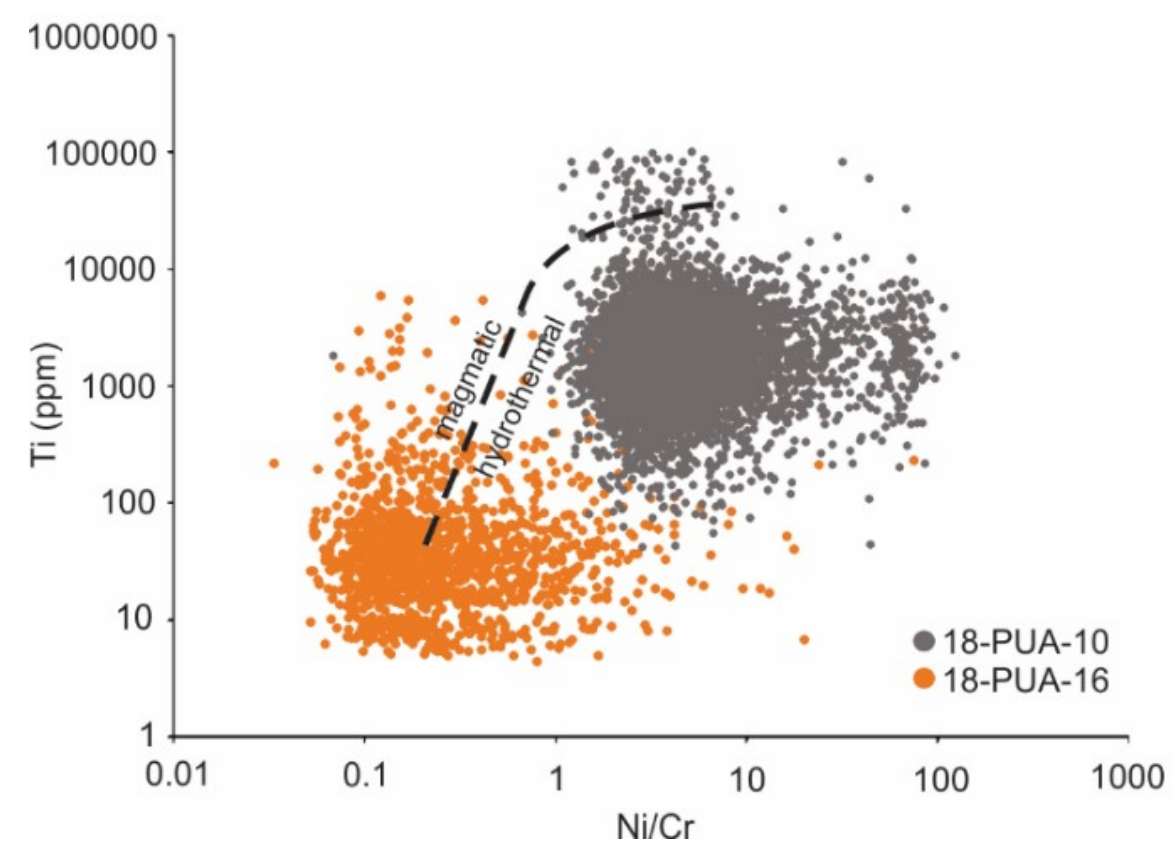

Fig. 3-6: Ti vs. Ni/Cr of magnetite from the two samples analyzed by LA-ICP-MS, the dotted line denotes the magmatic and hydrothermal magnetite zones, modified from Dare et al (2014).

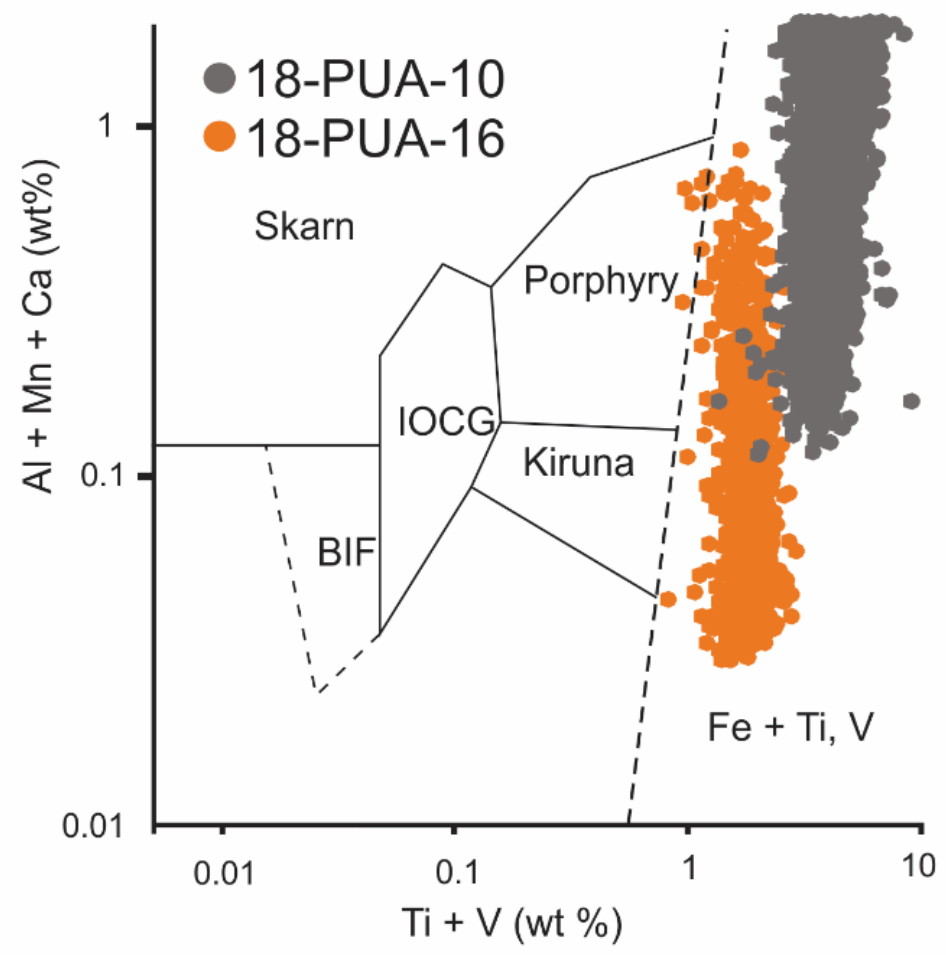

Fig. 3-7: Magnetite discrimination plot (in wt \%) where the dotted line denotes the magmatic Fe $+\mathrm{Ti}, \mathrm{V}$ deposit field, modified from Dupuis and Beaudoin (2011). 
Differences in V and Sn contents of IOAA-type magnetite have been interpreted to reflect differences in fluid temperature and oxygen fugacity, where an increase in oxidation and a decrease in temperature of the hydrothermal fluid can lead to a decrease in V and an increase in Sn contents of magnetite (Carew, 2004; Righter et al., 2006; Huang et al., 2019).

Magnetite of this study is characterized by high $\mathrm{V}$ contents (up to $9 \mathrm{wt} \%$ ) and low Sn (up to $10 \mathrm{ppm}$ ), possibly reflective of a high temperature, reduced fluid (Carew, 2004; Righter et al., 2006; Huang et al., 2019). Both the geochemical characteristics described and the nature of uraninite mineralization in sample 18-CD-10 which overgrows primary magnetite, could further support the interpretation of section 2.5 .3 that the source fluid of the primary uraninite was of a higher temperature and more reduced nature than that of the remobilized uraninite.

The Nori IOCG occurrence in the Great Bear Magmatic Zone (see section 2.6.1 for a description of the occurrence) hosts uraninite that is geochemically similar to the Kitts deposit uraninite (Acosta-Gongora et al., 2014; Potter et al., 2014, accepted). Major element contents of the Nori magnetite are similar to that of the Kitts-Post Hill belt magnetite. The Kitts-Post Hill belt magnetite may have a similar fluid source to the Nori magnetite, also interpreted to potentially be reduced and high temperature in origin (Acosta-Gongora et al., 2014).

Trace element patterns of both samples overlap with the IOCG field as defined by Huang et al. (2019) with the exception of vanadium (Fig. 3-3b). Incompatible elements of sample $18-C D-10$ are enriched relative to sample $18-C D-16$ and all other 
reference deposits. Compatible elements $(\mathrm{Zn}-\mathrm{Cr})$ are enriched and variable compared to the flat pattern of the average BIF. Compatible element contents vary wildly, with $\mathrm{V}$ and Zn contents similar to the magmatic Bushveld deposit while $\mathrm{Ni}$ and $\mathrm{Cr}$ contents are more similar to hydrothermal IOCG deposits.

Magnetite in the sample suite has low Ti and Al contents, similar to hydrothermal magnetite characterized by Dare et al. (2014). Magnetite is enriched in more immobile elements (e.g., $\mathrm{Zr}$ and $\mathrm{Hf}$ ), similar to uraninite element maps of section 2.5.3, which may reflect an enrichment of these elements in the mineralization fluid. Magnetite is enriched in compatible elements (e.g., Zn-Cr in Fig. 3-3), similar to the Bushveld deposit (Fe-Ti-P type), characteristic of high temperature hydrothermal deposits (Dare et al., 2014). The depletions in both $\mathrm{Ti}$ and $\mathrm{Al}$, as well as the enrichments in compatible elements and "immobile" elements point to a high temperature hydrothermal fluid origin, enriched in "immobile" and HFSE elements, similar to fluids suggested from uraninite data.

Trace element patterns of both samples show that magnetite is depleted in $\mathrm{Mg}$. This is reflected in the trace element maps as amphibole is enriched in $\mathrm{Mg}$ relative to magnetite, which suggests that $\mathrm{Mg}$ is being taken up by amphibole. Co-crystalizing titanite in sample 18-CD-16 may be taking up Ti at the expense of magnetite, reflected by the Ti depletion in the trace element pattern of magnetite. An enrichment of $\mathrm{Zr}, \mathrm{UO}_{2}$, $\mathrm{Pb}$ and $\mathrm{Al}_{2} \mathrm{O}_{3}$ is observed along fractures of magnetite (similar to that observed in uraninite element maps of section 2.5.3), which may reflect alteration by fluids, where the more compatible elements in magnetite are not as affected (Fig. 3-5). While it 
appears in the trace element maps that there are two geochemically distinct generations of magnetite, this is difficult to distinguish by the trace element patterns.

Evans (1980) proposed a U-V relationship in the Kitts deposit, based on whole rock geochemical data. However, our results indicate that $\mathrm{V}$ is hosted primarily in magnetite, where magnetite predates uranium mineralization. 


\subsection{Zircon U-Pb geochronology}

\subsection{Methods}

\subsubsection{SHRIMP}

Zircon $\mathrm{U}-\mathrm{Pb}$ analyses were performed on one sample each from the Kitts (sample 18-CD-14a) and Gear (sample 17-CD-002) deposits. Zircon U-Pb geochronology was performed on a sensitive high-resolution ion microprobe (SHRIMP) at the Geological Survey of Canada Geochronology Laboratory in Ottawa, Canada. The SHRIMP analytical procedures followed in this study are described by Stern (1997), with standards and U$\mathrm{Pb}$ calibration methods following Stern and Amelin (2003). Zircon grains were analyzed by drilling the grains from thin sections, and mounting the resulting disks in epoxy. Mount surfaces were evaporatively coated with $10 \mathrm{~nm}$ of high purity Au. Analyses on zircon grains were conducted using a ${ }^{16} \mathrm{O}$ - primary beam at $10 \mathrm{kV}$. The sputtered area used for analysis was $6 \mu \mathrm{m}$ (K30 aperture) in diameter with a beam current of 0.5-0.7 $\mathrm{nA}$. The count rates at eleven masses including background were sequentially measured over six scans with a single electron multiplier and a pulse counting system with deadtime of 21 ns. SQUID 2.5 software written by Ludwig (2009) was used to process the data. The 1 sigma external errors of ${ }^{206} \mathrm{~Pb} /{ }^{238} \mathrm{U}$ ratios reported in the data table incorporate a $\pm 0.8 \%$ error in calibrating the 6266 zircon reference mineral (accepted value $=559.2 \pm 0.2 \mathrm{Ma}$; Stern and Amelin, 2003). The primary standard zircon used was number 6266. No fractionation correction was applied to the $\mathrm{Pb}$-isotope data based on a value of $2687 \pm 22 \mathrm{Ma}(\mathrm{MSWD}=0.7, \mathrm{n}=6)$ for the 1242 standard zircon with the range of the accepted value of $2679.8 \pm 0.2 \mathrm{Ma}$ (Davis et al., 2018). The common $\mathrm{Pb}$ 
correction utilized the Pb composition of the surface blank (Stern, 1997). Isoplot v. 4.00

(Ludwig, 2003) was used to generate Concordia plots and calculate weighted means.

The error ellipses on the Concordia diagrams, and the weighted mean errors are reported with 2 sigma errors.

\subsubsection{Electric pulse disaggregation}

Two samples from the Kitts deposit were sent to Overburden Drilling Management (ODM), in Ottawa, Ontario, and processed using electric-pulse disaggregation (EPD). Samples were chosen from the historical collection of Sunil S. Gandhi at the GSC, and were characterized by their extremely high uranium content and presence of zircon in thin sections. A Spark 2 electric-pulse disaggregator was used to fragment the rocks along zones of weakness, using high-voltage electrical pulses. This produced both a heavy mineral concentrate, and a "zircon" concentrate. Zircon grains were very fine-grained, and were not used for geochronology in this study.

\subsection{Results}

\subsubsection{Petrography}

Sample 18-CD-14a (Fig. 4-1b,c) is an argillite composed of a matrix of finegrained (<500 um) amphibole and albite, with disseminated uraninite that formed clusters/veinlets (<500 um) and minor fine-grained disseminated pyrite, arsenopyrite, titanite, graphite and zircon ( $<500 \mathrm{um}$ ).

Sample 17-CD-002 (Fig. 4-1a) is an intercalated felsic-mafic volcanic rock composed of alternating layers of a mafic-type layer of fine-grained amphibole, biotite, 
plagioclase and minor quartz and a felsic layer of fine-grained plagioclase and quartz with minor amphibole. Minor zircon, titanite, muscovite, apatite and allanite occur throughout the sample.
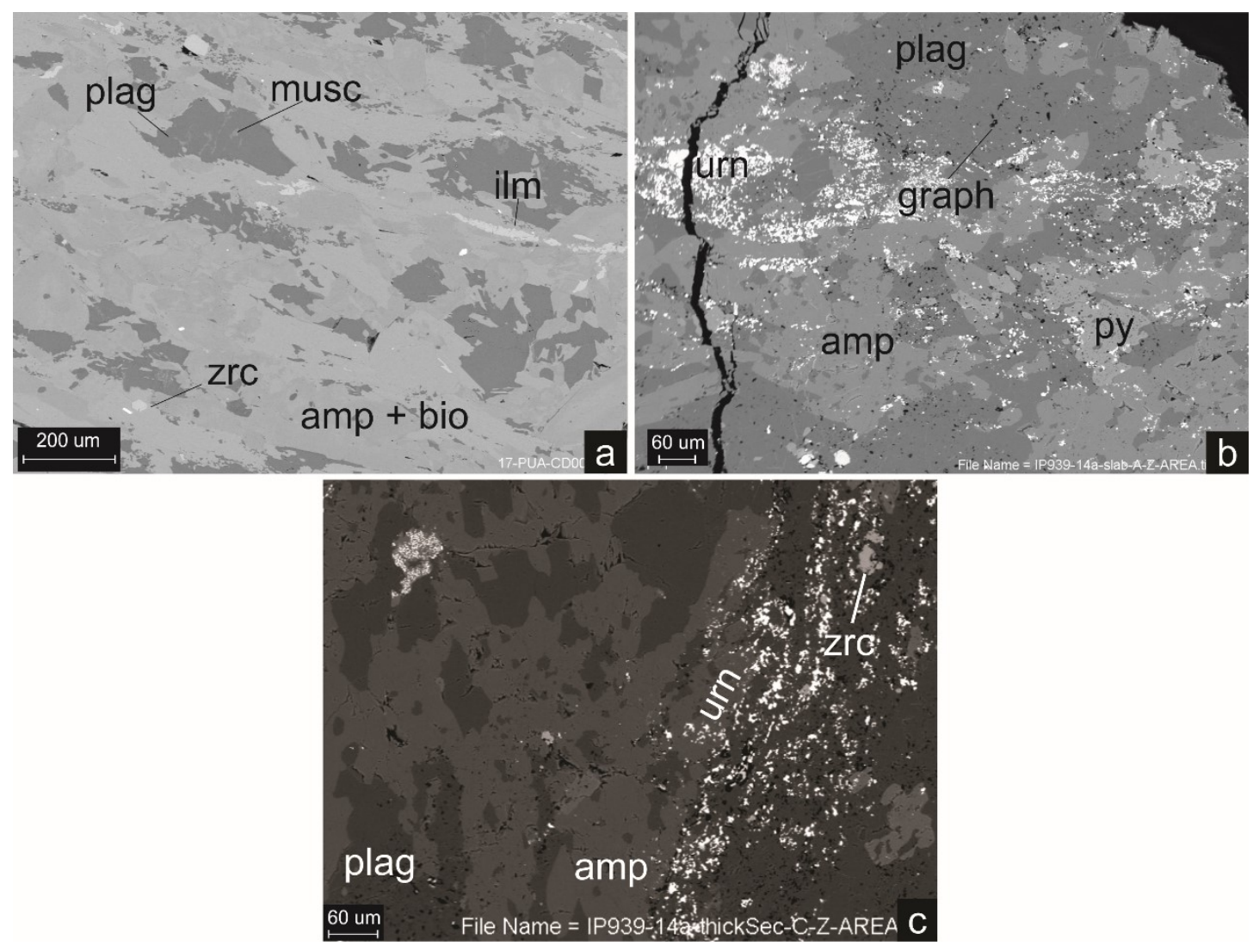

Fig. 4-1: BSE images of (a) fine-grained amphibole and biotite matrix with fine-grained plagioclase that contains inclusions of muscovite, and fine-grained zircon and ilmenite from sample 17-CD-002 of the Gear deposit. (b) Fine-grained amphibole and plagioclase matrix with disseminated fine-grained uraninite, graphite and pyrite from sample 18CD-014a of the Kitts deposit. (c) Fine-grained amphibole and plagioclase matrix with disseminated fine-grained uraninite and veinlet uraninite with fine grained zircon intergrown from sample 18-CD-14a of the Kitts deposit. Abbreviations: amphibole (amp), biotite (bio), graph (graphite), ilmenite (ilm), muscovite (musc), plagioclase (plag), pyrite (py), urn (uraninite), zircon (zrc). 


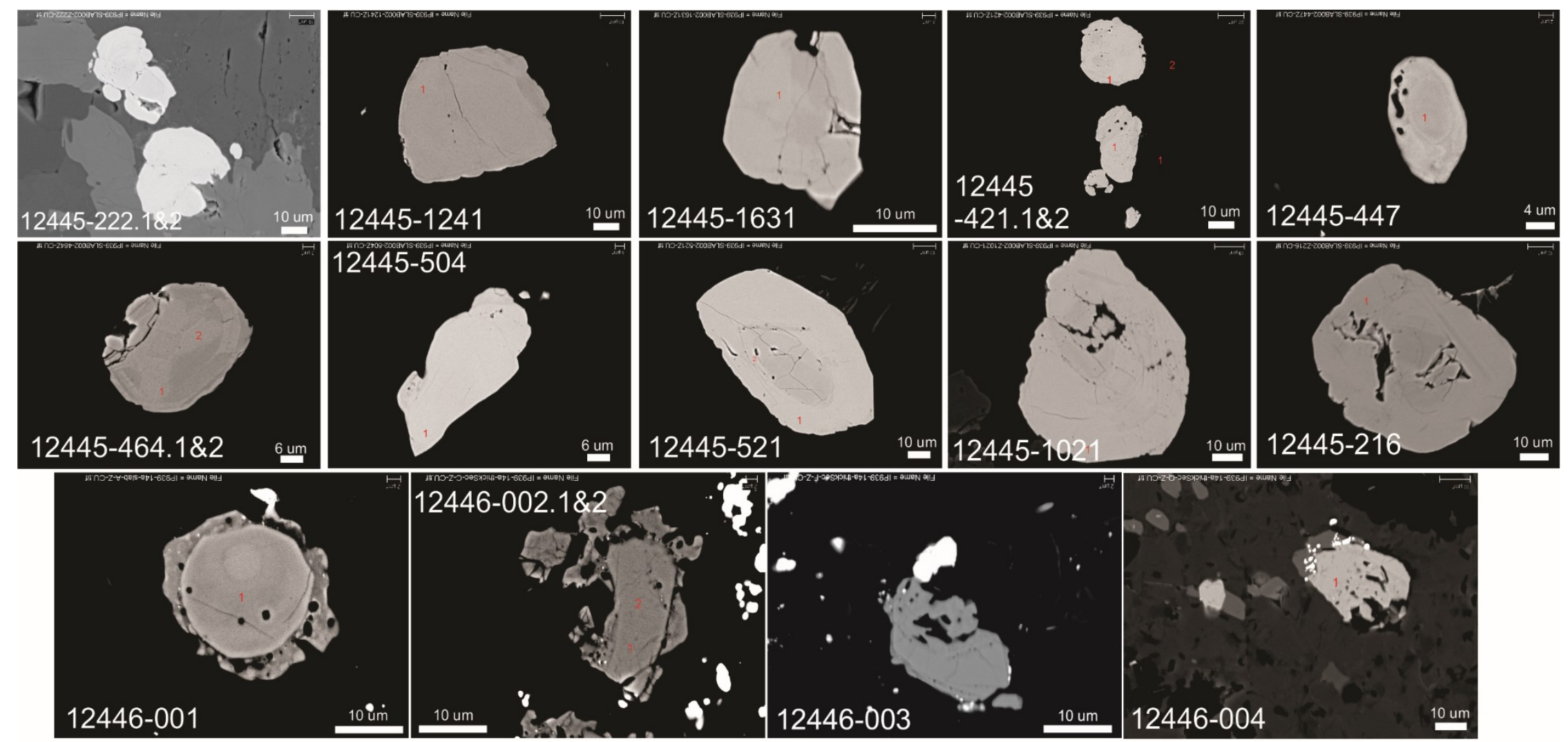

Fig. 4-2: BSE images of the zircons analyzed by SHRIMP, listed in Table 4-1, zircons (light grey), uraninite (white). 


\subsubsection{Zircon SHRIMP geochronology}

Results of the SHRIMP zircon analyses are given in Table 4-1. The spot names 12446 and 12445 correspond to samples 18-CD-14a and 17-CD-002 respectively. Images of the analyzed zircons are given in Fig. 4-2.

A single concordant Paleoproterozoic zircon from the Kitts deposit was measured with a ${ }^{207} \mathrm{~Pb} /{ }^{206} \mathrm{~Pb}$ age of $1868 \mathrm{Ma}$. All other zircons analyzed, from both the Kitts and Gear deposit, gave Archean ages. 
Table 4-1: SHRIMP zircon geochronology data, corrected for common ${ }^{204} \mathrm{~Pb}$.

\begin{tabular}{|c|c|c|c|c|c|c|c|c|c|c|c|c|c|c|}
\hline SPOT & $\begin{array}{c}\text { U } \\
\text { (PPM) }\end{array}$ & TH (PPM) & $\begin{array}{c}{ }^{207} \mathrm{~Pb} / \\
{ }^{235} \mathrm{U}\end{array}$ & \% ERR & $\begin{array}{c}{ }^{206} \mathrm{~Pb} / \\
{ }^{238} \mathrm{U}\end{array}$ & $\begin{array}{c}\% \\
\text { ERR }\end{array}$ & $\begin{array}{c}\text { ERR } \\
\text { COEF }\end{array}$ & $\begin{array}{c}{ }^{207} \mathrm{~Pb} / \\
{ }^{206} \mathrm{~Pb}\end{array}$ & $\begin{array}{c}\% \\
\text { ERR }\end{array}$ & $\begin{array}{l}{ }^{206} \mathrm{~Pb} / \\
{ }^{238} \mathrm{U} \\
\mathrm{AGE} \\
(\mathrm{Ma})\end{array}$ & ERR & $\begin{array}{l}{ }^{207} \mathrm{~Pb} / \\
{ }^{206} \mathrm{~Pb} \\
\mathrm{AGE} \\
(\mathrm{Ma})\end{array}$ & ERR & $\begin{array}{c}\% \\
\text { DISC }\end{array}$ \\
\hline $12446-002.1$ & 769 & 6 & 11.566 & 1.4 & 0.491 & 1.2 & 1 & 0.171 & 0.9 & 2577 & 24 & 2564 & 14 & -1 \\
\hline $12446-002.2$ & 844 & 12 & 11.017 & 1.3 & 0.467 & 1.2 & 0.9 & 0.171 & 0.5 & 2472 & 24 & 2567 & 9 & 4 \\
\hline $12446-004.1$ & 2479 & 23 & 5.074 & 4.7 & 0.322 & 3.8 & 0.8 & 0.114 & 2.8 & 1800 & 60 & 1868 & 50 & 4 \\
\hline 12445-1021.1 & 638 & 158 & 12.551 & 1.5 & 0.494 & 1.3 & 0.9 & 0.184 & 0.7 & 2589 & 28 & 2691 & 11 & 5 \\
\hline 12445-1241.1 & 554 & 78 & 12.048 & 1.4 & 0.485 & 1.3 & 0.9 & 0.180 & 0.7 & 2547 & 27 & 2656 & 11 & 5 \\
\hline 12445-1631.1 & 899 & 173 & 9.967 & 1.3 & 0.439 & 1.2 & 0.9 & 0.165 & 0.6 & 2346 & 23 & 2504 & 11 & 8 \\
\hline $12445-216.1$ & 465 & 95 & 11.157 & 2.3 & 0.463 & 2.1 & 0.9 & 0.175 & 1.0 & 2453 & 42 & 2603 & 17 & 7 \\
\hline $12445-222.1$ & 615 & 140 & 12.066 & 1.9 & 0.490 & 1.8 & 0.9 & 0.179 & 0.7 & 2572 & 38 & 2639 & 11 & 3 \\
\hline $12445-222.2$ & 115 & 42 & 12.169 & 3.0 & 0.473 & 2.3 & 0.8 & 0.187 & 1.9 & 2495 & 47 & 2714 & 31 & 10 \\
\hline $12445-421.1$ & 614 & 95 & 9.467 & 1.5 & 0.410 & 1.2 & 0.8 & 0.167 & 0.8 & 2217 & 23 & 2531 & 14 & 15 \\
\hline $12445-421.2$ & 579 & 84 & 9.343 & 2.3 & 0.413 & 2.1 & 0.9 & 0.164 & 1.0 & 2228 & 40 & 2498 & 16 & 13 \\
\hline $12445-464.1$ & 1000 & 207 & 8.730 & 1.3 & 0.415 & 1.1 & 0.9 & 0.152 & 0.6 & 2240 & 21 & 2373 & 10 & 7 \\
\hline $12445-464.2$ & 939 & 207 & 8.782 & 1.3 & 0.414 & 1.1 & 0.9 & 0.154 & 0.6 & 2235 & 21 & 2387 & 11 & 8 \\
\hline $12445-504.1$ & 629 & 134 & 12.395 & 1.4 & 0.502 & 1.2 & 0.9 & 0.179 & 0.7 & 2621 & 27 & 2646 & 11 & 1 \\
\hline $12445-521.1$ & 523 & 89 & 11.332 & 3.3 & 0.470 & 3.3 & 1.0 & 0.175 & 0.8 & 2482 & 67 & 2606 & 13 & 6 \\
\hline
\end{tabular}




\subsection{Discussion}

Zircon grains analyzed by SHRIMP were thought to be of hydrothermal origin based on the morphology of zircon grains in both samples, and their co-precipitating relationship with uraninite mineralization in vein-like features as shown in sample 18CD-14a (Fig. 4-1). Zircon grains from the Kitts deposit show clear signs of alteration, visible in Fig. 4-2 photo 12446-001, which shows a relatively intact core and an altered rim.

Aillik domain Archean basement rocks (ca. $2813 \pm 16 / 13 \mathrm{Ma}$ ) are overlain by the ca. 2235 Ma Post Hill Group, the host to the samples analyzed (Ketchum et al., 2002). Archean zircon grains have been reported from some Post Hill Group units, therefore it is likely that most of the zircon grains analyzed reflect a detrital Archean source. Zircon grains from samples $17-C D-002$ and $18-C D-14 a$ were not used to create isochrons, as they are likely detrital and therefore may reflect different sources. A single zircon from sample 18-CD-14a plotted concordantly at ca. $1800 \mathrm{Ma}$ and may reflect a hydrothermal origin (Fig. 4-3).

The concordant zircon at ca. 1800 Ma gave a younger age than the mineralization age (1881-2018 Ma) proposed by Sparkes et al. (2010), and may represent a remobilization age ca. $1800 \mathrm{Ma}$. This could be interpreted as a product of heat production in the area from syntectonic Makkovikian plutonism (ca. 1840-1800 Ma), more specifically the Long Island Quartz Monzonite $1802 \pm 13 / 7$ Ma (Kerr et al., 1992). 
Multiple zircon grains were found in the heavy mineral separate generated by the electric-pulse disaggregation method. This zircon separation was attempted in order to do LA-ICP-MS depth profiling, on zircon grains that were characterized as hydrothermal and/or bearing micron-scale overgrowths and possibly associated with uranium mineralization. Some were too small to be used for the LA-ICP-MS depth profile geochronology technique, while others were lost from the tape in the SEM during the initial vacuum step. Unfortunately, only a single zircon grain of adequate size was found, not enough to accurately date the mineralization.

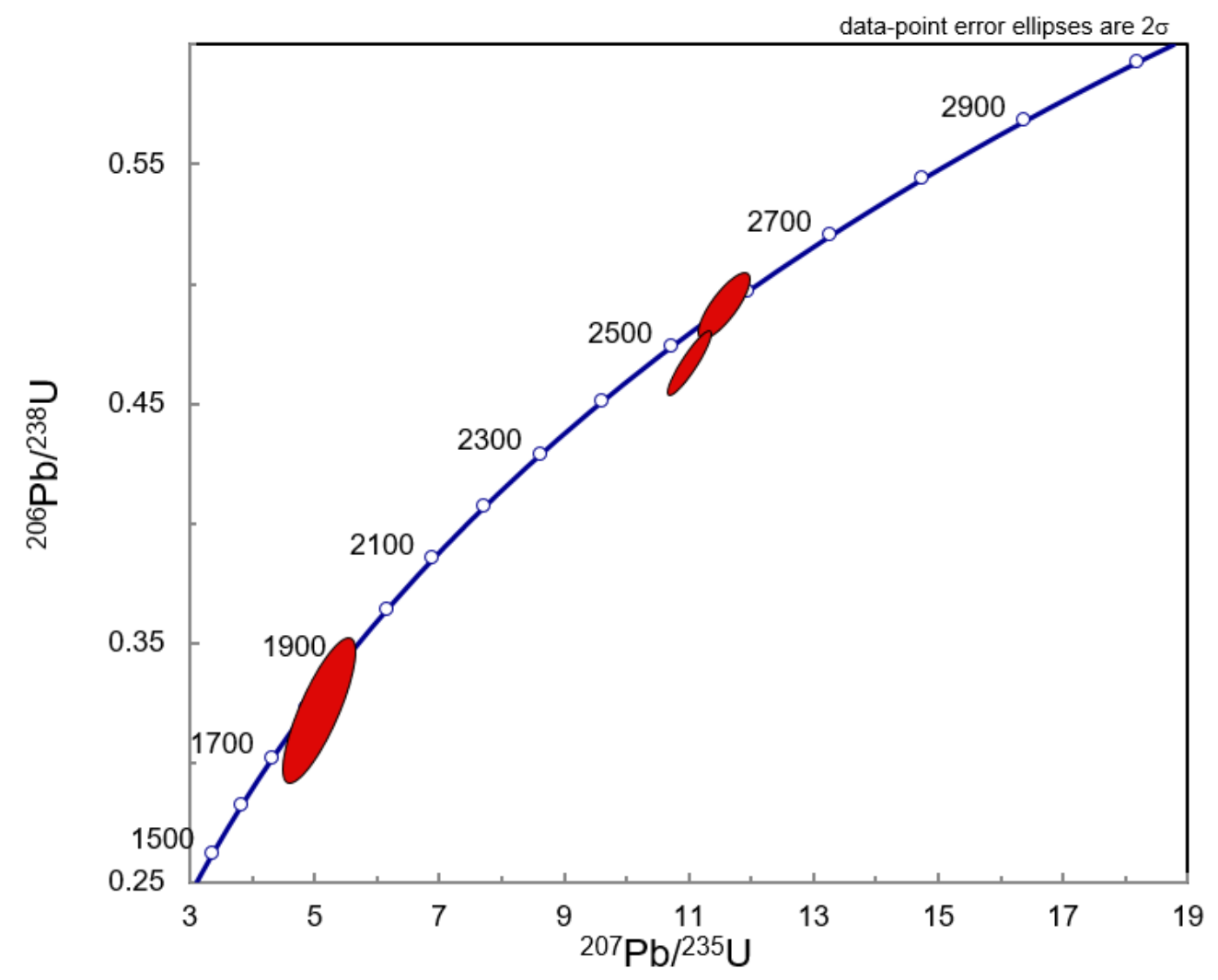

Fig. 4-3: Concordia plot of zircon grains from sample 18-CD-14a 


\subsection{Conclusion}

It has been well established that IOAA systems exhibit widespread and intense hydrothermal-metasomatic alteration assemblages (Hitzman et al., 1992; Corriveau and Mumin, 2010; Corriveau et al., 2010, 2016). Under the right tectonic conditions, albititehosted uranium deposits have also been documented to occur within these systems (Montreuil et al., 2015; Potter et al., 2019). From this study, trace element mineral chemistry, alteration and mineral assemblages suggest a potential IOAA association (regional $\mathrm{Na}, \mathrm{Ca}-\mathrm{Fe}$, and possibly K-Fe alteration) associated with uraninite mineralization.

Differences in uraninite geochemistry are interpreted to record three different events at the Kitts deposit. The $\mathrm{Zr}$ and $\mathrm{Nb}$ enrichment associated with uraninite suggest primary high temperature, fluids capable of moving high field strength elements. Late transition metal enrichment is associated with late iron oxide alteration, at times crosscutting uraninite. Enrichment of $\mathrm{Zr}, \mathrm{LREE}, \mathrm{U}$ and $\mathrm{Pb}$ along grain boundaries and fractures within the matrix support late-remobilization of these elements during alteration of the uraninite. Enrichment of LREE in rims compared to cores of uraninite grains support the findings of Martz et al. (2019) that disruption of primary REE signatures is possible under certain fluid conditions, particularly $\mathrm{Cl}$-rich fluids (Migdisov et al., 2016).

Uraninite from the Kitts deposit exhibits bell to pseudo-bell shaped REE patterns, with an increasing LREE/HREE ratio with increasing alteration/remobilization. The 
positive Eu anomalies of Group 2 uraninite may reflect leaching of Eu from plagioclase and/or amphibole rich rocks where by these minerals selectively remove Eu during crystallization, but release Eu when altered (Lottermoser, 1992), or remobilization by fluids with higher oxygen fugacity (Drake, 1975); the latter of which is supported by the late hematite mineralization (Hemmingway, 1990). Uraninite chondrite normalized REE patterns are similar to those of the Domes region deposits in Zambia (Eglinger et al., 2014). Total REE contents and U/Th ratios of uraninite are similar to that of the Mistamisk deposit (Lach et al., 2013; this study). This suggests a similar metasomatic fluid source for the Kitts-Post Hill belt to that of both the Domes region and Mistamisk deposit, which have been proposed to be Ca-Na metasomatic in origin with potential IOAA linkages (Corriveau et al., 2014; Eglinger et al., 2014).

Differences in magnetite geochemistry can be interpreted as two, possibly three, mineralization events within the Kitts-Post Hill belt. Major elements of magnetite in the Kitts-Post Hill belt are similar to the magnetite of the Nori IOCG occurrence in the Great Bear magmatic zone, analyzed by Acosta-Góngora et al. (2014). The V content of the Kitts-Post Hill belt magnetite is unusually high, characteristic of magnetite from magmatic $\mathrm{Fe}, \mathrm{Ti}+\mathrm{V}$ deposits as opposed to IOCG type magnetite, supporting the high temperature source fluid proposed for primary uraninite. This slightly contradicts the hydrothermal origin for magnetite as determined by the Ni/Cr plot by Dare et al. (2014). Bulk continental crust normalized trace element patterns reflect a high temperature hydrothermal mineralizing fluid, enriched in "immobile" and high field strength elements. A V enrichment is associated with magnetite that predates uranium 
mineralization, suggesting a $\mathrm{V}$-Fe relationship as opposed to a $\mathrm{V}-\mathrm{U}$ relationship (Evans, 1980).

Zircon $\mathrm{U}-\mathrm{Pb}$ geochronology did not accurately date the mineralization age of the uraninite, but the results could be interpreted as a remobilization event ca. $1800 \mathrm{Ma}$. This is consistent with the $\mathrm{U}-\mathrm{Pb}$ data that suggested three populations of uraninite, all younger than the Sparkes et al. (2010) primary mineralization age (1881-2018 Ma). Preliminary uraninite $\mathrm{U}-\mathrm{Pb}$ geochronology studies revealed that uraninite of the Kitts deposit experienced a remobilization event ca. 1640 Ma.

Sparkes and Kerr (2008) describe the diversity of uranium mineralization in the $\mathrm{CMB}$ as "bewildering"; the same could be said of the geochemical variations of the uranium mineralization in the Kitts-Post Hill belt. Differences in uraninite and magnetite geochemistry point to a complex hydrothermal fluid history, where the primary signatures have been altered by the many regional metamorphic-plutonic episodes.

\subsection{Future research}

Due to the fine-grained nature of the uraninite in the sample suite, only uraninite from the Kitts deposit was geochemically analyzed by LA-ICP-MS. As such, future work on uraninite of the Gear, Inda and Nash deposits is needed in order to fully characterize the Kitts-Post Hill belt.

Originally, this study was proposed to be a component of a larger field mapping and geochemistry project along the entire $\mathrm{CMB}$. However, financial and logistical constraints refocussed the study to a detailed examination of uraninite and magnetite 
mineralization using archival hand samples and industry drill core from the GSC and Newfoundland and Labrador Geological Survey. Field mapping of regional alteration footprints in IOAA-type systems was an important tool used by Corriveau et al. (2010) to distinguish vectors to potential mineralized areas. As such, future work in the Kitts-Post Hill belt should include regional-deposit scale mapping, as well as supporting whole rock geochemical analyses. Geochemical analyses would also permit creation of elemental "barcodes", which allows for visualization of regional-scale alteration facies evolution (Corriveau et al., 2016, 2018).

This study analyzed magnetite from the Inda and Gear deposits, but additional samples from the Kitts and Nash deposits is needed to further characterize the magnetite mineralization of the Kitts-Post Hill to fully understand the fluid origin, and the significance of the vanadium enrichment.

Timing of uraninite mineralization in the Kitts-Post Hill belt remains poorly defined. This study proposed a remobilization age for uraninite of the Kitts deposit at ca. $1800 \mathrm{Ma}$ and ca. $1640 \mathrm{Ma}$ based on zircon U-Pb geochronology from SHRIMP data and uraninite U-Pb geochronology from EMPA data. The vein-hosted nature and anhedral textures of zircon suggest a hydrothermal origin, but the reliability of the geochronology was hindered by the small sample suite and small size of the zircon grains. Electric pulse disaggregation was attempted in order to produce a larger sample suite of zircon grains, but unfortunately only a few zircon grains were in the concentrate and those were very fine-grained (average $<50 \mathrm{um}$ ). Uraninite $\mathrm{U}-\mathrm{Pb}$ dating was attempted from the LA-ICPMS mapping data, but the errors produced were too large to give reliable ages. More 
precise results could be obtained by reducing the number of elements being analysed and adjusting the laser raster rates. Future work on uraninite of the Kitts-Post Hill belt is recommended to confirm the remobilization ages suggested for the Kitts deposit, as well as to determine the primary mineralization age. 
6.0 Appendix

Appendix A: Major oxides (wt\%) EMPA data for uraninite analyses

\begin{tabular}{|c|c|c|c|c|c|c|c|c|c|c|c|c|c|c|}
\hline \multirow{2}{*}{$17-C D-025$} & $\mathrm{SiO}_{2}$ & $\mathrm{UO}_{2}$ & $\mathrm{PbO}$ & $\mathrm{CaO}$ & $\mathrm{La}_{2} \mathrm{O}_{3}$ & $\mathrm{Ce}_{2} \mathrm{O}_{3}$ & $\mathrm{Nd}_{2} \mathrm{O}_{3}$ & $\mathrm{Sm}_{2} \mathrm{O}_{3}$ & $\mathrm{FeO}$ & $\mathrm{ThO}_{2}$ & $\mathrm{P}_{2} \mathrm{O}_{5}$ & $\mathrm{Y}_{2} \mathrm{O}_{3}$ & $\mathrm{ZrO}_{2}$ & Total \\
\hline & & & & & & & & & & & & & & \\
\hline GC2-6 & 0.38 & 73.94 & 19.54 & 0.46 & 0.12 & 0.06 & 0.05 & - & 1.55 & 0.57 & - & 0.76 & 0.08 & 97.56 \\
\hline GC3-1 & - & 76.04 & 21.02 & 0.11 & - & 0.15 & 0.06 & 0.19 & 0.55 & 0.97 & - & 0.87 & 0.05 & $10-$ \\
\hline GC3-2 & 0.62 & 70.14 & 20.29 & 0.15 & - & 0.31 & 0.42 & 0.12 & 0.59 & 1.01 & - & 0.58 & 1.86 & 96.09 \\
\hline \multirow[t]{12}{*}{ 17-CD-027 } & $\mathrm{SiO}_{2}$ & $\mathrm{UO}_{2}$ & $\mathrm{PbO}$ & $\mathrm{CaO}$ & $\mathrm{La}_{2} \mathrm{O}_{3}$ & $\mathrm{Ce}_{2} \mathrm{O}_{3}$ & $\mathrm{Nd}_{2} \mathrm{O}_{3}$ & $\mathrm{Sm}_{2} \mathrm{O}_{3}$ & $\mathrm{FeO}$ & $\mathrm{ThO}_{2}$ & $\mathrm{P}_{2} \mathrm{O}_{5}$ & $\mathrm{Y}_{2} \mathrm{O}_{3}$ & $\mathrm{ZrO}_{2}$ & Total \\
\hline & - & 74.19 & 20.87 & 0.10 & - & - & 0.10 & 0.11 & 0.23 & - & - & 1.40 & 0.09 & 95.40 \\
\hline & - & 72.79 & 19.78 & 0.24 & 0.12 & 0.18 & 0.29 & - & 0.27 & - & - & 2.74 & 0.37 & 96.34 \\
\hline & - & 73.26 & 20.50 & 0.25 & 0.17 & 0.14 & 0.22 & 0.07 & 0.21 & 0.13 & - & 2.82 & 0.41 & 95.05 \\
\hline & - & 73.48 & 20.82 & 0.19 & - & - & 0.06 & 0.12 & 0.26 & 0.05 & - & 1.80 & 0.20 & 96.15 \\
\hline & - & 72.16 & 20.75 & 0.16 & - & 0.15 & 0.24 & 0.23 & 0.15 & - & - & 2.07 & 0.14 & 95.55 \\
\hline & 0.94 & 72.76 & 19.26 & 0.61 & 0.35 & - & - & - & 0.17 & 0.08 & - & 1.28 & 0.08 & 95.18 \\
\hline & - & 75.74 & 20.60 & 0.15 & - & - & 0.19 & 0.28 & 0.80 & - & - & 1.05 & - & 96.10 \\
\hline & - & 72.74 & 20.60 & 0.19 & - & - & 0.20 & 0.08 & 0.26 & - & - & 1.92 & 0.19 & 96.56 \\
\hline & - & 75.27 & 20.74 & 0.26 & 0.06 & 0.14 & 0.10 & 0.23 & 0.32 & 0.07 & - & 1.63 & 0.07 & 96.76 \\
\hline & - & 75.04 & 20.38 & 0.14 & 0.18 & 0.16 & 0.36 & 0.15 & 0.49 & 0.14 & - & 1.35 & - & 95.75 \\
\hline & - & 75.03 & 21.01 & 0.25 & - & 0.24 & 0.16 & 0.19 & 0.25 & 0.06 & - & 1.57 & - & 96.24 \\
\hline \multirow[t]{5}{*}{ 17-CD-024 } & $\mathrm{SiO}_{2}$ & $\mathrm{UO}_{2}$ & $\mathrm{PbO}$ & $\mathrm{CaO}$ & $\mathrm{La}_{2} \mathrm{O}_{3}$ & $\mathrm{Ce}_{2} \mathrm{O}_{3}$ & $\mathrm{Nd}_{2} \mathrm{O}_{3}$ & $\mathrm{Sm}_{2} \mathrm{O}_{3}$ & $\mathrm{FeO}$ & $\mathrm{ThO}_{2}$ & $\mathrm{P}_{2} \mathrm{O}_{5}$ & $\mathrm{Y}_{2} \mathrm{O}_{3}$ & $\mathrm{ZrO}_{2}$ & Total \\
\hline & - & 74.98 & 21.22 & - & - & 0.06 & 0.35 & 0.10 & 0.77 & 2.05 & - & 1.15 & - & 100.73 \\
\hline & - & 73.09 & 20.16 & 0.07 & 0.36 & 0.20 & 0.14 & - & 0.23 & 2.22 & - & 1.13 & - & 97.61 \\
\hline & 0.11 & 75.48 & 21.55 & 0.09 & - & 0.07 & 0.16 & - & 0.39 & 2.51 & - & 1.14 & - & 101.60 \\
\hline & - & 72.91 & 20.63 & 0.15 & 0.11 & 0.17 & - & 0.20 & 0.63 & 2.43 & - & 1.41 & 0.07 & 98.81 \\
\hline GS-08-266-02 & $\mathrm{SiO}_{2}$ & $\mathrm{UO}_{2}$ & $\mathrm{PbO}$ & $\mathrm{CaO}$ & $\mathrm{La}_{2} \mathrm{O}_{3}$ & $\mathrm{Ce}_{2} \mathrm{O}_{3}$ & $\mathrm{Nd}_{2} \mathrm{O}_{3}$ & $\mathrm{Sm}_{2} \mathrm{O}_{3}$ & $\mathrm{FeO}$ & $\mathrm{ThO}_{2}$ & $\mathrm{P}_{2} \mathrm{O}_{5}$ & $\mathrm{Y}_{2} \mathrm{O}_{3}$ & $\mathrm{ZrO}_{2}$ & Total \\
\hline 1 & 0.09 & 77.05 & 21.29 & 0.18 & 0.11 & 0.10 & 0.37 & - & 0.21 & - & - & 0.26 & 0.12 & 99.90 \\
\hline
\end{tabular}




\begin{tabular}{|c|c|c|c|c|c|c|c|c|c|c|c|c|c|c|}
\hline 2 & 0.07 & 75.40 & 21.66 & 0.22 & - & 0.23 & 0.16 & - & 0.23 & 0.07 & - & 0.22 & 0.16 & 98.48 \\
\hline 3 & 0.07 & 76.99 & 20.10 & 0.09 & - & 0.15 & 0.22 & 0.05 & 0.06 & - & - & 0.26 & 0.10 & 98.10 \\
\hline 4 & - & 76.88 & 20.67 & 0.19 & 0.39 & - & 0.07 & 0.18 & 0.14 & 0.11 & - & 0.36 & - & 99.17 \\
\hline 5 & - & 77.60 & 21.10 & 0.19 & - & 0.28 & - & - & 0.63 & 0.10 & - & 0.37 & - & 100.44 \\
\hline 6 & 0.39 & 75.89 & 20.68 & 0.18 & - & 0.28 & 0.14 & - & 0.69 & 0.08 & - & 0.42 & - & 98.37 \\
\hline 7 & 0.18 & 77.28 & 19.88 & 0.31 & - & - & - & 0.20 & 0.11 & 0.12 & - & 0.33 & - & 98.32 \\
\hline 8 & 0.19 & 76.98 & 20.69 & 0.36 & - & 0.38 & 0.17 & 0.11 & 0.15 & - & - & 0.26 & - & 99.28 \\
\hline 9 & 0.14 & 76.73 & 19.74 & 0.32 & - & - & 0.16 & - & 0.09 & - & - & 0.22 & - & 97.32 \\
\hline 10 & 0.10 & 77.63 & 21.00 & 0.22 & - & 0.21 & 0.15 & 0.05 & 0.07 & 0.12 & - & 0.30 & - & 99.80 \\
\hline 11 & 0.14 & 76.69 & 20.10 & 0.27 & 0.23 & 0.12 & 0.18 & - & 0.14 & 0.13 & - & 0.20 & - & 98.13 \\
\hline 12 & 0.09 & 77.13 & 20.65 & 0.19 & 0.26 & - & 0.30 & 0.14 & 0.17 & 0.12 & - & 0.26 & - & 99.26 \\
\hline 13 & 0.06 & 76.30 & 20.63 & 0.28 & 0.09 & 0.09 & 0.08 & - & 0.23 & 0.25 & - & 0.12 & - & 98.14 \\
\hline 14 & 0.53 & 75.69 & 18.92 & 0.32 & 0.22 & 0.15 & 0.20 & 0.06 & 0.35 & - & - & 0.31 & 4.02 & 100.29 \\
\hline 15 & 0.09 & 78.14 & 21.10 & 0.23 & - & - & 0.30 & - & 0.09 & 0.19 & - & 0.20 & 0.14 & 100.52 \\
\hline 18 & 0.23 & 76.74 & 17.97 & 0.42 & - & - & 0.27 & - & 0.32 & - & - & 0.35 & - & 96.10 \\
\hline 22 & 0.13 & 73.66 & 21.30 & 0.12 & - & 0.11 & 0.12 & - & 0.30 & 0.14 & - & 0.19 & - & 96.00 \\
\hline GS-08-266-01a & $\mathrm{SiO}_{2}$ & $\mathrm{UO}_{2}$ & $\mathrm{PbO}$ & $\mathrm{CaO}$ & $\mathrm{La}_{2} \mathrm{O}_{3}$ & $\mathrm{Ce}_{2} \mathrm{O}_{3}$ & $\mathrm{Nd}_{2} \mathrm{O}_{3}$ & $\mathrm{Sm}_{2} \mathrm{O}_{3}$ & $\mathrm{FeO}$ & $\mathrm{ThO}_{2}$ & $\mathrm{P}_{2} \mathrm{O}_{5}$ & $\mathrm{Y}_{2} \mathrm{O}_{3}$ & $\mathrm{ZrO}_{2}$ & Total \\
\hline 1 & 0.06 & 78.03 & 21.03 & 0.36 & - & 0.11 & 0.39 & 0.07 & 0.14 & 0.06 & - & 0.21 & - & 100.42 \\
\hline 2 & 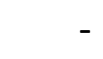 & 77.77 & 21.17 & 0.16 & 0.17 & 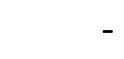 & 0.10 & 0.09 & 0.06 & 0.13 & - & 0.19 & - & 99.93 \\
\hline 3 & 0.10 & 76.51 & 20.48 & 0.22 & 0.16 & 0.16 & 0.27 & 0.05 & 0.07 & 0.14 & - & 0.07 & 0.16 & 98.44 \\
\hline 4 & 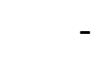 & 77.09 & 21.04 & 0.17 & - & 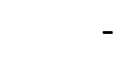 & 0.38 & 0.11 & 0.08 & 0.17 & - & 0.17 & - & 99.29 \\
\hline 5 & 0.11 & 77.67 & 20.44 & 0.26 & - & 0.33 & 0.12 & - & 0.72 & - & - & 0.26 & 0.08 & 100.12 \\
\hline 6 & 0.15 & 77.35 & 20.27 & 0.25 & - & 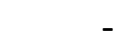 & 0.30 & 0.07 & 0.12 & - & - & 0.21 & - & 98.63 \\
\hline 7 & - & 77.47 & 19.74 & 0.23 & 0.05 & 0.07 & 0.10 & 0.10 & 0.13 & - & 0.05 & 0.20 & - & 98.16 \\
\hline 8 & 0.10 & 76.88 & 21.02 & 0.19 & - & 0.09 & 0.20 & - & 0.12 & 0.12 & - & 0.14 & - & 98.81 \\
\hline 9 & 0.05 & 76.33 & $2-$ & 0.22 & 0.17 & - & 0.28 & 0.10 & 0.19 & - & - & 0.14 & - & 97.45 \\
\hline 10 & 0.11 & 75.82 & 20.78 & 0.24 & 0.12 & 0.26 & 0.15 & 0.11 & 0.30 & - & - & 0.17 & - & 97.96 \\
\hline 11 & 0.14 & 77.02 & 20.87 & 0.21 & 0.18 & - & 0.26 & - & 0.11 & - & - & 0.08 & 0.10 & 99.00 \\
\hline 13 & 0.06 & 77.36 & 21.30 & 0.27 & - & 0.08 & 0.20 & - & 0.13 & 0.07 & - & 0.17 & 0.11 & 99.87 \\
\hline
\end{tabular}




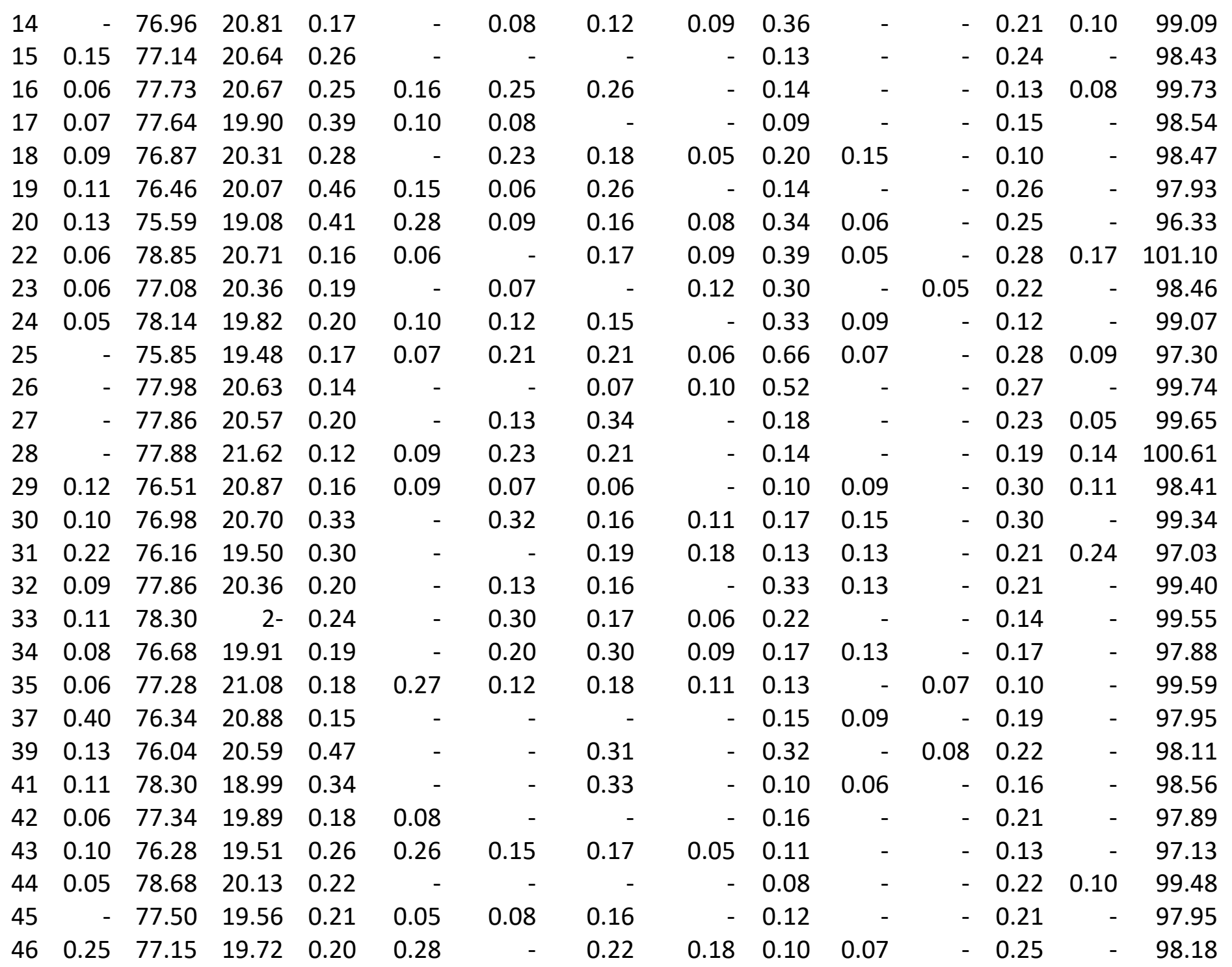




\begin{tabular}{|c|c|c|c|c|c|c|c|c|c|c|c|c|c|c|}
\hline 47 & 0.10 & 77.24 & 20.06 & 0.19 & - & 0.19 & 0.11 & - & 0.35 & 0.06 & - & 0.29 & - & 98.54 \\
\hline 49 & 0.17 & 77.64 & 20.33 & 0.34 & - & 0.16 & 0.25 & - & 0.11 & - & - & 0.22 & - & 99.21 \\
\hline 50 & 0.07 & 76.81 & 20.75 & 0.23 & - & - & 0.19 & - & 0.07 & - & - & 0.12 & - & 98.26 \\
\hline 51 & 0.12 & 77.16 & 20.23 & 0.33 & - & 0.13 & - & 0.15 & 0.09 & 0.13 & - & 0.25 & - & 98.64 \\
\hline 52 & 0.08 & 77.24 & 20.31 & 0.25 & - & 0.12 & 0.13 & 0.05 & 0.15 & - & - & 0.35 & 0.05 & 98.72 \\
\hline 53 & 0.14 & 76.71 & 20.16 & 0.24 & - & 0.24 & 0.33 & 0.07 & 0.15 & - & - & 0.21 & 0.11 & 98.24 \\
\hline 54 & 0.07 & 76.82 & 21.30 & 0.21 & - & - & 0.17 & - & 0.12 & 0.06 & - & 0.23 & 0.05 & 99.12 \\
\hline 55 & 0.22 & 74.70 & 19.24 & 0.47 & - & 0.12 & 0.21 & - & 0.10 & 0.12 & - & 0.30 & 0.37 & 95.62 \\
\hline 56 & 0.07 & 77.46 & 20.32 & 0.25 & - & - & 0.27 & - & 0.06 & - & - & 0.10 & - & 98.57 \\
\hline 57 & 0.18 & 74.31 & 20.26 & 0.37 & 0.15 & - & 0.14 & - & 0.07 & - & - & 0.17 & - & 95.58 \\
\hline 58 & 0.05 & 76.66 & 21.03 & 0.19 & - & 0.05 & 0.21 & 0.19 & 0.11 & - & - & 0.19 & - & 98.79 \\
\hline 59 & 0.09 & 77.17 & 19.90 & 0.33 & 0.15 & - & 0.23 & - & 0.19 & 0.10 & - & 0.15 & 0.07 & 98.34 \\
\hline GS-08-266-01b & $\mathrm{SiO}_{2}$ & $\mathrm{UO}_{2}$ & $\mathrm{PbO}$ & $\mathrm{CaO}$ & $\mathrm{La}_{2} \mathrm{O}_{3}$ & $\mathrm{Ce}_{2} \mathrm{O}_{3}$ & $\mathrm{Nd}_{2} \mathrm{O}_{3}$ & $\mathrm{Sm}_{2} \mathrm{O}_{3}$ & $\mathrm{FeO}$ & $\mathrm{ThO}_{2}$ & $\mathrm{P}_{2} \mathrm{O}_{5}$ & $\mathrm{Y}_{2} \mathrm{O}_{3}$ & $\mathrm{ZrO}_{2}$ & Total \\
\hline 2 & - & 76.36 & 20.22 & 0.15 & 0.08 & 0.10 & 0.14 & - & 0.06 & - & - & 0.10 & - & 97.32 \\
\hline 3 & 0.84 & 76.00 & 18.74 & 0.85 & - & 0.17 & 0.18 & - & - & 0.15 & 0.09 & 0.32 & - & 96.58 \\
\hline 4 & 0.09 & 76.31 & 20.51 & 0.16 & 0.09 & 0.14 & 0.15 & - & 0.05 & 0.10 & - & 0.12 & - & 97.72 \\
\hline 5 & - & 76.43 & 20.48 & 0.27 & 0.12 & - & 0.19 & 0.15 & 0.10 & 0.11 & - & 0.25 & - & 98.13 \\
\hline 6 & - & 76.57 & 20.58 & 0.27 & - & 0.20 & 0.31 & - & 0.11 & - & - & 0.18 & - & 98.30 \\
\hline 7 & - & 75.54 & 20.37 & 0.16 & - & 0.18 & 0.28 & 0.06 & 0.05 & - & - & 0.17 & - & 96.86 \\
\hline 8 & - & 76.43 & $2-$ & 0.20 & - & - & 0.14 & 0.06 & 0.15 & - & - & 0.25 & - & 97.35 \\
\hline 9 & - & 78.78 & 20.52 & 0.22 & 0.21 & 0.16 & 0.10 & - & 0.05 & - & - & 0.24 & - & 100.36 \\
\hline 11 & 0.06 & 76.64 & 19.46 & 0.16 & - & 0.11 & 0.26 & - & 0.22 & - & - & 0.17 & - & 97.05 \\
\hline 12 & 0.05 & 78.81 & 19.14 & 0.50 & 0.10 & - & 0.06 & - & 0.19 & - & - & 0.20 & - & 99.12 \\
\hline 13 & 0.54 & 76.54 & 19.51 & 0.42 & - & - & 0.12 & 0.06 & 0.27 & - & - & 0.18 & - & 97.14 \\
\hline 14 & - & 78.47 & 19.79 & 0.19 & - & 0.21 & 0.25 & - & 0.49 & 0.09 & 0.05 & 0.20 & 0.05 & 99.78 \\
\hline 16 & 0.10 & 78.11 & 19.20 & 0.70 & - & 0.05 & 0.18 & - & 0.12 & - & - & 0.13 & 0.08 & 98.66 \\
\hline 17 & 0.23 & 76.80 & 19.89 & 0.27 & - & - & 0.26 & - & 0.27 & 0.14 & - & 0.11 & 0.08 & 97.85 \\
\hline 18 & 0.07 & 77.70 & 19.63 & 0.40 & 0.31 & 0.09 & - & - & 0.25 & 0.18 & 0.05 & 0.22 & - & 98.92 \\
\hline 19 & 0.08 & 77.31 & 20.62 & 0.15 & - & 0.13 & 0.23 & 0.08 & 0.29 & - & - & - & - & 98.93 \\
\hline
\end{tabular}




\begin{tabular}{|c|c|c|c|c|c|c|c|c|c|c|c|c|c|c|}
\hline 20 & 0.12 & 75.43 & $2-$ & 0.22 & 0.19 & 0.14 & 0.32 & - & 0.49 & - & - & 0.17 & - & 96.99 \\
\hline 21 & 0.26 & 75.34 & 19.65 & 0.50 & 0.10 & - & 0.10 & - & 0.49 & - & - & 0.15 & - & 96.34 \\
\hline 22 & 0.16 & 78.03 & 19.20 & 0.27 & 0.25 & - & - & 0.09 & 0.37 & - & - & 0.22 & - & 98.50 \\
\hline 24 & 0.33 & 76.54 & 21.01 & 0.32 & - & 0.07 & 0.35 & - & 0.24 & - & - & 0.29 & 0.06 & 98.94 \\
\hline 25 & 0.05 & 77.14 & 19.64 & 0.25 & 0.14 & 0.30 & - & - & 0.22 & - & - & 0.28 & 0.12 & 98.17 \\
\hline 26 & - & 75.11 & 20.69 & 0.20 & - & - & 0.16 & - & 0.11 & - & - & 0.30 & - & 96.73 \\
\hline 27 & 0.22 & 76.18 & 20.94 & 0.22 & - & 0.06 & 0.14 & - & 0.18 & - & - & 0.16 & 0.18 & 98.27 \\
\hline 28 & 0.12 & 76.92 & 20.06 & 0.16 & - & 0.07 & 0.16 & - & 0.10 & - & - & - & - & 97.46 \\
\hline 29 & 0.15 & 76.44 & 20.06 & 0.51 & 0.17 & 0.18 & 0.20 & - & 0.09 & 0.05 & 0.05 & 0.13 & - & 97.90 \\
\hline GS-08-266-01c & $\mathrm{SiO}_{2}$ & $\mathrm{UO}_{2}$ & $\mathrm{PbO}$ & $\mathrm{CaO}$ & $\mathrm{La}_{2} \mathrm{O}_{3}$ & $\mathrm{Ce}_{2} \mathrm{O}_{3}$ & $\mathrm{Nd}_{2} \mathrm{O}_{3}$ & $\mathrm{Sm}_{2} \mathrm{O}_{3}$ & $\mathrm{FeO}$ & $\mathrm{ThO}_{2}$ & $\mathrm{P}_{2} \mathrm{O}_{5}$ & $\mathrm{Y}_{2} \mathrm{O}_{3}$ & $\mathrm{ZrO}_{2}$ & Total \\
\hline 1 & 0.11 & 77.37 & 21.39 & 0.19 & 0.05 & - & 0.18 & - & 0.06 & - & - & 0.19 & 0.08 & 99.60 \\
\hline 2 & 0.25 & 77.01 & 19.13 & 0.11 & - & 0.09 & 0.11 & 0.08 & 0.10 & - & - & 0.28 & 0.06 & 97.04 \\
\hline 3 & 0.18 & 77.71 & 20.63 & 0.29 & 0.07 & - & 0.24 & 0.05 & - & 0.09 & - & 0.28 & - & 99.44 \\
\hline 4 & 0.15 & 78.39 & 19.68 & 0.33 & 0.26 & 0.08 & 0.43 & - & 0.28 & - & - & 0.22 & 0.07 & 99.73 \\
\hline 5 & 0.23 & 75.53 & 20.36 & 0.30 & - & 0.05 & - & - & 0.16 & - & - & 0.10 & 0.11 & 96.90 \\
\hline 6 & 0.17 & 78.26 & 20.78 & 0.27 & - & 0.23 & 0.06 & - & 0.12 & 0.16 & 0.05 & 0.10 & - & 100.09 \\
\hline 7 & 0.10 & 77.87 & 19.65 & 0.16 & - & 0.06 & 0.34 & 0.14 & 0.14 & - & - & 0.19 & - & 98.55 \\
\hline 8 & 0.06 & 77.24 & 20.77 & 0.47 & - & 0.42 & 0.05 & - & 0.06 & 0.07 & - & 0.26 & - & 99.41 \\
\hline 9 & 0.27 & 75.63 & 19.64 & 0.33 & - & - & 0.23 & 0.05 & 0.09 & 0.12 & - & 0.10 & 0.15 & 96.42 \\
\hline 10 & 0.08 & 77.48 & 19.77 & 0.12 & 0.09 & 0.27 & 0.13 & 0.05 & 0.07 & - & - & 0.22 & - & 98.21 \\
\hline 11 & 0.06 & 78.09 & 20.93 & 0.12 & - & 0.21 & 0.12 & 0.06 & 0.08 & - & - & 0.06 & - & 99.77 \\
\hline 12 & 0.12 & 77.23 & 20.57 & 0.21 & 0.21 & - & 0.29 & - & 0.13 & 0.12 & - & 0.10 & - & 99.03 \\
\hline 13 & 0.14 & 76.32 & 20.73 & 0.24 & - & - & 0.35 & - & 0.14 & 0.10 & - & 0.15 & 0.16 & 98.32 \\
\hline 14 & 0.44 & 77.91 & 18.99 & 0.40 & - & 0.05 & 0.23 & - & 0.14 & 0.07 & - & 0.21 & - & 98.06 \\
\hline 15 & - & 76.33 & 20.53 & 0.23 & - & - & 0.18 & - & - & 0.08 & - & 0.25 & - & 97.67 \\
\hline 17 & 0.06 & 78.73 & 18.80 & 0.19 & - & 0.08 & 0.21 & 0.10 & - & 0.18 & - & 0.16 & - & 98.51 \\
\hline 19 & 0.15 & 76.03 & 20.91 & 0.37 & 0.13 & 0.17 & 0.06 & 0.11 & 0.10 & - & - & 0.21 & 0.06 & 98.18 \\
\hline 20 & 0.14 & 76.61 & 20.34 & 0.26 & - & 0.06 & 0.05 & 0.11 & 0.26 & - & 0.06 & 0.16 & 0.11 & 98.09 \\
\hline 21 & 0.22 & 78.26 & 18.40 & 0.13 & - & - & 0.15 & - & 0.86 & 0.17 & - & 0.17 & & 98.21 \\
\hline
\end{tabular}




\begin{tabular}{|c|c|c|c|c|c|c|c|c|c|c|c|c|c|c|}
\hline 22 & 0.06 & 77.85 & 20.30 & 0.16 & - & - & 0.09 & - & 0.08 & - & - & 0.18 & - & 98.70 \\
\hline 23 & 0.22 & 76.15 & 19.57 & 0.38 & - & 0.10 & 0.19 & 0.05 & 0.09 & - & - & 0.18 & 0.07 & 96.79 \\
\hline 24 & 0.16 & 76.40 & 21.41 & 0.49 & - & - & 0.15 & 0.19 & 0.11 & - & - & 0.11 & - & 98.97 \\
\hline 26 & 0.07 & 76.05 & 20.38 & 0.23 & - & 0.23 & 0.12 & 0.06 & 0.08 & - & - & 0.28 & 0.05 & 97.69 \\
\hline 27 & 0.19 & 76.39 & 21.21 & 0.42 & - & - & 0.14 & 0.12 & 0.47 & - & - & 0.23 & - & 99.08 \\
\hline 28 & 0.21 & 75.89 & 20.12 & 0.30 & 0.13 & 0.15 & 0.06 & - & 0.23 & - & - & - & 0.06 & 97.07 \\
\hline 29 & 0.24 & 78.97 & 19.88 & 0.89 & 0.16 & 0.18 & 0.18 & - & 0.19 & 0.17 & - & 0.19 & 0.09 & 100.98 \\
\hline 30 & 0.10 & 77.75 & 20.38 & 0.22 & - & 0.10 & 0.11 & 0.12 & - & 0.07 & - & 0.13 & 0.06 & 98.98 \\
\hline 31 & 0.42 & 76.18 & 19.03 & 0.39 & - & 0.09 & - & - & 0.33 & 0.16 & - & 0.13 & - & 96.36 \\
\hline 32 & 0.17 & 78.08 & 19.43 & 0.44 & 0.07 & - & 0.14 & - & 0.14 & - & - & 0.12 & - & 98.58 \\
\hline S-08-267-01 & $\mathrm{SiO}_{2}$ & $\mathrm{UO}_{2}$ & $\mathrm{PbO}$ & $\mathrm{CaO}$ & $\mathrm{La}_{2} \mathrm{O}_{3}$ & $\mathrm{Ce}_{2} \mathrm{O}_{3}$ & $\mathrm{Nd}_{2} \mathrm{O}_{3}$ & $\mathrm{Sm}_{2} \mathrm{O}_{3}$ & $\mathrm{FeO}$ & $\mathrm{ThO}_{2}$ & $\mathrm{P}_{2} \mathrm{O}_{5}$ & $\mathrm{Y}_{2} \mathrm{O}_{3}$ & $\mathrm{ZrO}_{2}$ & Total \\
\hline 1 & 0.10 & 75.30 & 19.61 & 0.38 & - & 0.18 & 0.14 & - & 0.70 & - & - & 0.17 & 0.08 & 96.73 \\
\hline 2 & 0.08 & 75.39 & 20.53 & 0.16 & - & 0.10 & 0.11 & 0.07 & 0.40 & - & - & 0.12 & - & 96.92 \\
\hline 2 & 0.07 & 76.44 & 20.78 & 0.23 & - & 0.22 & 0.10 & 0.10 & 0.44 & - & - & 0.18 & 0.09 & 98.60 \\
\hline 3 & 0.09 & 76.64 & 20.33 & 0.23 & 0.26 & - & 0.12 & - & 0.74 & - & - & 0.09 & 0.09 & 98.63 \\
\hline 6 & 0.19 & 77.68 & 18.46 & 0.61 & - & 0.18 & 0.14 & 0.12 & 0.21 & - & 0.06 & 0.15 & - & 97.68 \\
\hline 7 & 0.10 & 73.77 & 26.17 & 0.18 & 0.21 & 0.06 & 0.39 & - & 0.43 & 0.12 & - & 0.16 & 0.08 & 101.74 \\
\hline 8 & 0.18 & 72.86 & 24.66 & 0.28 & - & 0.09 & 0.24 & 0.06 & 0.34 & 0.15 & - & 0.10 & - & 98.82 \\
\hline 9 & 0.32 & 78.71 & 18.68 & 1.00 & 0.07 & - & 0.20 & - & 0.26 & 0.05 & - & 0.09 & - & 99.22 \\
\hline 10 & - & 78.62 & 19.27 & 0.31 & - & - & 0.08 & - & 0.29 & - & - & 0.09 & - & 98.76 \\
\hline 11 & 0.09 & 77.96 & 19.66 & 0.27 & - & 0.09 & 0.31 & 0.06 & 0.27 & - & - & 0.13 & 0.11 & 98.89 \\
\hline 12 & 0.07 & 79.18 & 21.24 & 0.18 & - & 0.31 & 0.28 & - & 0.22 & 0.09 & - & 0.14 & - & 101.66 \\
\hline 13 & 0.07 & 77.89 & 19.44 & 0.19 & - & 0.25 & 0.33 & - & 0.28 & - & - & 0.24 & 0.10 & 98.82 \\
\hline 13 & 0.14 & 78.04 & 19.47 & 0.50 & - & 0.07 & 0.16 & - & 0.49 & - & - & 0.22 & - & 98.99 \\
\hline 14 & 0.08 & 78.17 & 19.45 & 0.55 & 0.22 & - & 0.17 & 0.12 & 0.42 & 0.05 & - & 0.17 & - & 99.37 \\
\hline 15 & 0.07 & 76.78 & 19.88 & 0.13 & - & 0.16 & - & 0.16 & 0.77 & 0.11 & - & 0.17 & - & 98.29 \\
\hline 16 & 0.05 & 78.32 & 20.26 & 0.25 & 0.08 & 0.06 & 0.17 & 0.09 & 0.43 & 0.05 & - & 0.11 & 0.05 & 99.93 \\
\hline 18 & 0.13 & 76.82 & 19.47 & 0.50 & 0.19 & - & 0.09 & - & 0.59 & 0.11 & 0.05 & 0.06 & - & 97.90 \\
\hline 19 & 0.13 & 76.99 & 20.75 & 0.22 & - & 0.08 & 0.27 & 0.05 & 0.77 & 0.05 & - & 0.36 & & 99.55 \\
\hline
\end{tabular}




\begin{tabular}{|c|c|c|c|c|c|c|c|c|c|c|c|c|c|c|}
\hline 21 & 0.12 & 73.23 & 19.93 & 0.16 & - & 0.25 & 0.16 & 0.12 & 0.48 & 0.10 & - & 0.57 & - & 95.08 \\
\hline \multirow[t]{11}{*}{ GS-08-267-0 } & $\mathrm{SiO}_{2}$ & $\mathrm{UO}_{2}$ & $\mathrm{PbO}$ & $\mathrm{CaO}$ & $\mathrm{La}_{2} \mathrm{O}_{3}$ & $\mathrm{Ce}_{2} \mathrm{O}_{3}$ & $\mathrm{Nd}_{2} \mathrm{O}_{3}$ & $\mathrm{Sm}_{2} \mathrm{O}_{3}$ & $\mathrm{FeO}$ & $\mathrm{ThO}_{2}$ & $\mathrm{P}_{2} \mathrm{O}_{5}$ & $\mathrm{Y}_{2} \mathrm{O}_{3}$ & $\mathrm{ZrO}_{2}$ & Total \\
\hline & 0.12 & 75.59 & 20.86 & 0.19 & - & 0.08 & 0.34 & - & 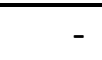 & - & - & 0.34 & - & 97.51 \\
\hline & 0.12 & 76.08 & 19.28 & 0.37 & - & 0.08 & 0.17 & 0.19 & 0.08 & - & - & 0.27 & - & 96.64 \\
\hline & 0.10 & 75.51 & 19.31 & 0.35 & - & - & 0.18 & - & 0.05 & - & - & 0.28 & 0.08 & 95.81 \\
\hline & 0.07 & 74.80 & 20.19 & 0.15 & - & 0.08 & - & - & - & - & - & 0.49 & 0.11 & 95.85 \\
\hline & 0.12 & 74.69 & 19.34 & 0.40 & - & 0.12 & 0.22 & 0.10 & 0.11 & 0.06 & 0.07 & 0.30 & - & 95.53 \\
\hline & 0.19 & 74.68 & 19.18 & 0.35 & - & 0.19 & 0.08 & - & 0.06 & - & - & 0.32 & 0.11 & 95.06 \\
\hline & 0.09 & 74.09 & $2-$ & 0.21 & 0.15 & - & 0.31 & - & 0.10 & - & - & 0.41 & - & 95.28 \\
\hline & - & 76.14 & 20.46 & 0.20 & - & 0.12 & 0.27 & - & 0.07 & - & 0.05 & 0.20 & - & 97.59 \\
\hline & 0.15 & 74.23 & 20.33 & 0.21 & - & - & 0.17 & 0.12 & 0.10 & - & - & 0.29 & 0.10 & 95.65 \\
\hline & 0.09 & 75.90 & 19.38 & 0.20 & - & 0.11 & 0.18 & - & 0.08 & - & 0.06 & 0.32 & - & 96.25 \\
\hline \multirow[t]{8}{*}{ 18-CD-14a-1 } & $\mathrm{SiO}_{2}$ & $\mathrm{UO}_{2}$ & $\mathrm{PbO}$ & $\mathrm{CaO}$ & $\mathrm{La}_{2} \mathrm{O}_{3}$ & $\mathrm{Ce}_{2} \mathrm{O}_{3}$ & $\mathrm{Nd}_{2} \mathrm{O}_{3}$ & $\mathrm{Sm}_{2} \mathrm{O}_{3}$ & $\mathrm{FeO}$ & $\mathrm{ThO}_{2}$ & $\mathrm{P}_{2} \mathrm{O}_{5}$ & $\mathrm{Y}_{2} \mathrm{O}_{3}$ & $\mathrm{ZrO}_{2}$ & Total \\
\hline & 0.29 & 76.70 & 21.22 & 0.30 & 0.12 & - & 0.09 & 0.09 & - & 0.10 & - & 0.12 & 0.46 & 99.32 \\
\hline & 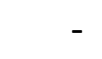 & 77.40 & 21.33 & 0.18 & - & 0.23 & - & - & - & - & 0.05 & 0.15 & - & 99.43 \\
\hline & - & 77.13 & 21.19 & 0.25 & - & 0.09 & 0.39 & - & 0.05 & 0.05 & 0.05 & 0.07 & - & 99.31 \\
\hline & 0.15 & 77.01 & 21.19 & 0.38 & 0.11 & 0.18 & 0.32 & - & - & - & 0.06 & 0.14 & - & 99.44 \\
\hline & 0.19 & 83.10 & 23.25 & 0.73 & 0.20 & - & 0.25 & - & 0.12 & 0.13 & - & 0.05 & 0.06 & 108.01 \\
\hline & 0.41 & 78.43 & 21.09 & 0.39 & 0.17 & - & 0.34 & - & 0.62 & - & - & 0.11 & - & 101.38 \\
\hline & 0.22 & 77.82 & 20.87 & 0.50 & 0.12 & 0.26 & 0.26 & - & 0.18 & - & - & 0.11 & - & 100.20 \\
\hline \multirow[t]{5}{*}{ 18-CD-14a-2 } & $\mathrm{SiO}_{2}$ & $\mathrm{UO}_{2}$ & $\mathrm{PbO}$ & $\mathrm{CaO}$ & $\mathrm{La}_{2} \mathrm{O}_{3}$ & $\mathrm{Ce}_{2} \mathrm{O}_{3}$ & $\mathrm{Nd}_{2} \mathrm{O}_{3}$ & $\mathrm{Sm}_{2} \mathrm{O}_{3}$ & $\mathrm{FeO}$ & $\mathrm{ThO}_{2}$ & $\mathrm{P}_{2} \mathrm{O}_{5}$ & $\mathrm{Y}_{2} \mathrm{O}_{3}$ & $\mathrm{ZrO}_{2}$ & Total \\
\hline & - & 78.06 & 22.00 & 0.26 & 0.30 & 0.19 & 0.24 & - & 0.05 & 0.18 & - & 0.07 & 0.08 & 101.51 \\
\hline & 0.05 & 78.06 & 21.89 & 0.28 & - & 0.20 & 0.41 & 0.11 & - & 0.07 & - & 0.17 & - & 101.25 \\
\hline & 0.62 & 76.66 & 21.20 & 0.31 & - & 0.16 & 0.24 & 0.06 & - & 0.18 & 0.07 & 0.10 & - & 99.26 \\
\hline & 0.12 & 78.50 & 21.05 & 0.40 & - & - & 0.36 & - & - & - & - & 0.13 & - & 100.63 \\
\hline \multirow[t]{3}{*}{ 18-CD-14a-3 } & $\mathrm{SiO}_{2}$ & $\mathrm{UO}_{2}$ & $\mathrm{PbO}$ & $\mathrm{CaO}$ & $\mathrm{La}_{2} \mathrm{O}_{3}$ & $\mathrm{Ce}_{2} \mathrm{O}_{3}$ & $\mathrm{Nd}_{2} \mathrm{O}_{3}$ & $\mathrm{Sm}_{2} \mathrm{O}_{3}$ & $\mathrm{FeO}$ & $\mathrm{ThO}_{2}$ & $\mathrm{P}_{2} \mathrm{O}_{5}$ & $\mathrm{Y}_{2} \mathrm{O}_{3}$ & $\mathrm{ZrO}_{2}$ & Total \\
\hline & 0.15 & 77.52 & 20.62 & 0.32 & - & 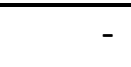 & 0.35 & - & 0.22 & 0.05 & 0.06 & 0.10 & - & 99.36 \\
\hline & 0.11 & 75.33 & 21.53 & 0.38 & - & 0.08 & 0.34 & - & 0.06 & 0.09 & - & 0.09 & - & 97.95 \\
\hline
\end{tabular}




\begin{tabular}{rlllllllllllrrr} 
& 0.06 & 76.42 & 21.56 & 0.33 & - & 0.10 & 0.15 & - & - & - & - & 0.16 & 0.05 & 98.89 \\
& 0.10 & 78.71 & 20.86 & 0.27 & 0.07 & 0.26 & 0.19 & - & 0.06 & - & - & 0.06 & 0.05 & 100.62 \\
& 0.08 & 77.12 & 21.30 & 0.28 & 0.28 & 0.18 & 0.33 & - & 0.08 & - & - & 0.13 & - & 99.70 \\
$18-\mathrm{CD}-14 \mathrm{~b}-1$ & $\mathrm{SiO}_{2}$ & $\mathrm{UO}_{2}$ & $\mathrm{PbO}$ & $\mathrm{CaO}$ & $\mathrm{La}_{2} \mathrm{O}_{3}$ & $\mathrm{Ce}_{2} \mathrm{O}_{3}$ & $\mathrm{Nd}_{2} \mathrm{O}_{3}$ & $\mathrm{Sm}_{2} \mathrm{O}_{3}$ & $\mathrm{FeO}$ & $\mathrm{ThO}_{2}$ & $\mathrm{P}_{2} \mathrm{O}_{5}$ & $\mathrm{Y}_{2} \mathrm{O}_{3}$ & $\mathrm{ZrO}_{2}$ & $\mathrm{Total}$ \\
\hline & 0.11 & 78.90 & 21.67 & 0.40 & 0.11 & 0.09 & 0.06 & - & - & - & - & 0.15 & 0.07 & 101.63 \\
& 0.53 & 76.78 & 21.06 & 0.56 & - & - & 0.26 & 0.07 & 0.13 & 0.12 & - & 0.05 & - & 99.12
\end{tabular}


Appendix B: LA-ICP-MS average element data for magnetite analyses in ppm unless otherwise noted

18-CD-10

18-CD-16

\begin{tabular}{llrlr} 
& Average & Std dev & Average & Std dev \\
\hline Si wt\% & 0.270 & 0.387 & 0.088 & 0.100 \\
Ca wt\% & 0.112 & 0.380 & 0.056 & 0.095 \\
Y & 20.093 & 137.929 & 0.237 & 1.447 \\
P wt \% & 0.088 & 0.250 & 0.008 & 0.010 \\
Pb & 434.808 & 2918.529 & 6.468 & 28.531 \\
Zr & 738.704 & 4318.854 & 26.175 & 461.731 \\
Hf & 3.722 & 23.284 & 0.550 & 8.761 \\
Al wt\% & 0.216 & 0.231 & 0.015 & 0.025 \\
Ge & - & - & - & - \\
W & 0.524 & 1.355 & 0.171 & 0.476 \\
Sc & - & - & - & - \\
Ta & 0.049 & 0.163 & 0.032 & 0.082 \\
Nb & 0.321 & 1.669 & 0.059 & 0.533 \\
Cu & 6.719 & 78.755 & 778.398 & 4838.712 \\
Mo & 0.542 & 1.053 & 0.408 & 0.951 \\
Sn & 1.469 & 1.458 & 0.573 & 0.646 \\
Ga & - & - & - & - \\
Mn wt\% & 0.256 & 0.182 & 307.996 & 78.491 \\
Mg wt\% & 0.086 & 0.170 & 0.013 & 0.038 \\
Ti wt\% & 0.265 & 0.385 & 0.009 & 0.035 \\
Zn & 1305.919 & 1293.008 & 110.373 & 803.895 \\
Co & 59.722 & 12.156 & 30.342 & 27.223 \\
V wt\% & 3.593 & 0.387 & 1.820 & 0.220 \\
Ni & 376.216 & 74.904 & 36.054 & 18.592 \\
Cr & 95.471 & 74.425 & 10.882 & 11.935
\end{tabular}




\subsection{References}

Acosta-Góngora, P., Potter, E.G., Corriveau, L., Lawley, C.J.M., and Sparkes, G.W., 2019, Geochemistry of $\mathrm{U} \pm \mathrm{Cu} \pm \mathrm{Mo} \pm \mathrm{V}$ mineralization, Central Mineral Belt, Labrador: differentiating between mineralization styles using a principal component analysis approach; in Targeted Geoscience Initiative: 2018 report of activities, (ed.) N. Rogers; Geological Survey of Canada, Open File 8549, p. 381-391.

Alexandre, P. \& Kyser, T.K., 2005, Effects of cationic substitution and alteration in uraninite and implications for the dating of uranium deposits, Canadian Mineralogist, v. 43, p. 1005-1017

Azimov, P.Y., Bushmin, S.A., 2007. Solubility of minerals of metamorphic and metasomatic rocks in hydrothermal solutions of varying acidity: thermodynamic modeling at $400-800{ }^{\circ} \mathrm{C}$ and $1-5$ kbar. Geochem. Int. 45, 1210-1234.

BHP, 2018, BHP Billiton Limited annual report 2018, 300 p. Available on: www.bhp.com/investor-centre.

Bowels, J., 2015, Age dating from electron microprobe analyses of U, Th, Ph: geological advantages and analytical difficulties, Microsc. Microanal, v. 21, p. 1114-1122.

Bruneton, P. 2014, "IAEA classification of uranium deposits." Vienna: IAEA.

Cadman, A.C., Heaman, L., Tarney, J., Wardle, R., and Krogh, T.E, 1993, U-Pb geochronology and geochemical variation within two Proterozoic mafic dyke swarms, Labrador. Canadian Journal of Earth Sciences, v. 30, p. 1490-1504. 
Carew, M.J., 2004, Controls on Cu-Au mineralization and Fe oxide metasomatism in the Eastern fold belt, N.W. Queensland, Australia: Unpublished Ph.D. thesis, Townsville, James Cook University, 308 p

Corriveau, L., and Mumin, A., 2010, Exploring for iron oxide copper-gold (Ag-Bi-Co-U) deposits: case examples, classification and exploration vectors, in Corriveau, L. and Mumin, A. eds., Exploring for iron oxide copper-gold deposits: Canada and global analogues, Geological Association of Canada, p. 89-110.

Corriveau, L., Williams, P., and Mumin, A., 2010, Alteration vectors to IOCG mineralization from uncharted terranes to deposits, in Corriveau, L. and Mumin, A. eds., Exploring for iron oxide copper-gold deposits: Canada and global analogues, Geological Association of Canada, p. 89-110.

Corriveau, L., Nadeau, O., Montreuil, J.-F., and Desrochers, J.-P., 2014, Report of activities for the Core Zone: Strategic geomapping and geoscience to assess the mineral potential of the Labrador Trough for multiple metals IOCG and affiliated deposits, Canada; Geological Survey of Canada, Open File 7714, 12 p. doi:10.4095/295529.

Corriveau, L., Montreuil, J.-F., and Potter, E.G., 2016, Alteration Facies Linkages Among Iron Oxide Copper-Gold, Iron Oxide-Apatite, and Affiliated Deposits in the Great Bear Magmatic Zone, Northwest Territories, Canada: Economic Geology, v. 111, p. 2045-2072, doi:10.2113/econgeo.111.8.2045. 
Corriveau, L., Potter, E.G., Montreuil, J.-F., Blein, O., Ehrig, K., and De Toni, A., 2018, Iron-oxide and alkali-calcic alteration ore systems and their polymetallic IOA, IOCG, skarn, albitite-hosted $U \pm A u \pm C o$, and affiliated deposits: a short course series. Part 2: overview of deposit types, distribution, ages, settings, alteration facies, and ore deposit models: Geological Survey of Canada, Scientific Presentation 81, $154 \mathrm{p}$.

Cuney, M., 2009, The extreme diversity of uranium deposits: Mineralium Deposita, v. 44, p. 3-9, doi: 10.1007/s00126-008-0223-1.

Cuney, M., Emetz, A., Mercadier, J., Mykchaylov, V., Shunko, V., and Yuslenko, A., 2012, Uranium deposits associated with Na-metasomatism from central Ukraine: A review of some of the major deposits and genetic constraints: Ore Geology Reviews, v. 44, p. 82-106, doi:10.1016/j.oregeorev.2011.09.007.

Dare, S.A.S., Barnes, S.-J., Beaudoin, G., Méric, J., Boutroy, E., and Potvin-Doucet, C., 2014, Trace elements in magnetite as petrogenetic indicators: Mineralium Deposita, v. 49, p. 785-796, doi:10.1007/s00126-014-0529-0.

Davis, W.J., Pestaj, T., Rayner, N., and McNicoll, V., 2018, Long-term reproducibility of $207 \mathrm{~Pb} / 206 \mathrm{~Pb}$ age at the GSC SHRIMP lab based on the GSC Archean reference zircon 1242. 9th International Shrimp Workshop, Korea Basic Science Institute. p. 107.

Desrochers, J.P., 2016, Exploration Report (fall 2014 drill Program) on the Sagar Property, Romanet Horst, Labrador Trough, Québec, Canada, Energizer 
Resources Inc, p. 73.

Drake, M.J., 1975, The oxidation state of europium as an indicator of oxygen fugacity: Geochimica et Cosmochimica Acta, v. 39, p. 55-64, doi:10.1016/00167037(75)90184-2.

Dupuis, C., and Beaudoin, G., 2011, Discriminant diagrams for iron oxide trace element fingerprinting of mineral deposit types: Mineralium Deposita, v. 46, p. 319-335, doi:10.1007/s00126-011-0334-y.

Eglinger, A., André-Mayer, A.-S., Vanderhaeghe, O., Mercadier, J., Cuney, M., Decrée, S., Feybesse, J.-L., and Milesi, J.-P., 2013, Geochemical signatures of uranium oxides in the Lufilian belt: From unconformity-related to syn-metamorphic uranium deposits during the Pan-African orogenic cycle: Ore Geology Reviews, v. 54, p. 197-213, doi:10.1016/j.oregeorev.2013.04.003.

Eglinger, A., Tarantola, A., Durand, C., Ferraina, C., Vanderhaeghe, O., André-Mayer, A.S., Paquette, J.-L., and Deloule, E., 2014, Uranium mobilization by fluids associated with $\mathrm{Ca}-\mathrm{Na}$ metasomatism: A P - T - t record of fluid-rock interactions during Pan-African metamorphism (Western Zambian Copperbelt): Chemical Geology, v. 386, p. 218-237, doi:10.1016/j.chemgeo.2014.07.028.

Gabelman, J.W., 1988, Classification of uranium deposits: Ore Geology Reviews, v. 3, p. 13-29, doi: 10.1016/0169-1368(88)90014-5. 
Gale, A., Dalton, C.A., Langmuir, C.H., Su, Y., and Schilling, J-G. 2003, The mean composition of ocean ridge basalts. Geochemistry, Geophysics, Geosystems, v. 14, p. 489-518.

Gandhi, S., 1978, Geological setting and genetic aspects of uranium occurences in the Kaipokok Bay-Big River area, Labrador: Economic Geology, v. 73, p. 1492-1522.

Golder, H.Q.1977, Feasibility study volume 2-geology and reserves and volume 6 geotechnical surveys for Kitts-Michelin project, Labrador. Newfoundland and Labrador Geological Survey, Assessment File LAB/0259, 583 pages.

Gower C.F., Flanagan, M.J., Kerr, A., and Bailet, D.G., 1982, Geology of the Kaipokok Bay - Big River area, Central Mineral Belt, Labrador, Newfoundland and Labrador Department of Mines and Energy, Mineral Development Division, Report 82-7.

Gower, C.F., Schärer, U., and Heaman, L.M., 1992, The Labradorian orogeny in the Grenville Province, eastern Labrador, Canada: Canadian Journal of Earth Sciences, v. 29, p. 1944-1957, doi:10.1139/e92-152.

Griffin, W.L., Powell, W.J., Pearson, N.J., and O'Reilly, S.Y., 2008, GLITTER: Data reduction software for laser ablation ICP-MS, in, Laser Ablation-ICP-Mass Spectrometry in the Earth Sciences: Current Practices and Outstanding Issues (Sylvester, P., Ed.), Mineralogical Association of Canada (MAC) Short Course Series, v. 40, p. 308-311. 
Groves, D.I., Bierlein, F.P., Meinert, L.D., and Hitzman, M.W., 2010, Iron Oxide CopperGold (IOCG) Deposits through Earth History: Implications for Origin, Lithospheric Setting, and Distinction from Other Epigenetic Iron Oxide Deposits: Economic Geology, v. 105, p. 641-654, doi:10.2113/gsecongeo.105.3.641.

Hemingway, B. S., 1990, Thermodynamic Properties for Bunsenite, NiO, Magnetite, Fe304, and Hematite, Fe2O3, with Comments on Selected Oxygen Buffer Reactions, American Mineralogist v. 75 (7-8), p. 781-790.

Hertel, M., Podhorski-Thomas, M., Durston, K., Edwards, C. and Allard, S. 2009, Michelin uranium project, Labrador, Canada, NI 43-101 technical report on preliminary economic assessment. NI 43-101F1 Technical Report, 221 pages.

Hinchey, A., 2007, The Paleoproterozoic metavolcanic, metasedimentary and igneous rocks of the Aillik domain, Makkovik province, Labrador (NTS map area 130/03: Newfoundland and Labrador Department of Resources Geologic Survey Report, p. $25-44$.

Hinchey, A.M. and Davis, W.J., 2013, New U-Pb zircon geochronology for the Measles Point Granite, Aillik Domain, Makkovik Province, Labrador (NTS map area 130/03). In Current Research. Government of Newfoundland and Labrador, Department of Natural Resources, Geological Survey, Report 13-1, p. 223-232.

Hitzman, M.W., Oreskes, N., and Einaudi, M.T., 1992, Geological characteristics and tectonic setting of proterozoic iron oxide (CU-U-Au-REE) deposits: Precambrian Research, v. 58, p. 241-287, doi:10.1016/0301-9268(92)90121-4. 
Hitzman, M.W., and Valenta, R.K., 2005, Uranium in iron-oxide-copper-gold (IOCG) systems: Economic Geology, v. 100, p. 1657-1661, doi:10.2113/gsecongeo.100.8.1657.

Huang, X.-W., Boutroy, É., Makvandi, S., Beaudoin, G., Corriveau, L., and De Toni, A.F., 2019, Trace element composition of iron oxides from IOCG and IOA deposits: relationship to hydrothermal alteration and deposit subtypes: Mineralium Deposita, v. 54, p. 525-552, doi:10.1007/s00126-018-0825-1.

IAEA. 2017, How China has Become the World's Fastest Expanding Nuclear Power Producer. https://www.iaea.org/newscenter/news/how-china-has-become-theworlds-fastest-expanding-nuclear-power-producer.

IAEA. 2016, IAEA Sees Global Nuclear Power Capacity Growing Through 2030. https://www.iaea.org/newscenter/pressreleases/iaea-sees-global-nuclearpower-capacity-growing-through-2030.

Jackson, S.E., 2008, Calibration strategies for elemental analysis by LA-ICP-MS, in, Laser Ablation-ICP-Mass Spectrometry in the Earth Sciences: Current Practices and Outstanding Issues (Sylvester, P., Ed.), Mineralogical Association of Canada (MAC) Short Course Series, v. 40, p. 169-188.

Jackson, S.E., 2008, LAMTRACE data reduction software for LA-ICP-MS, in, Laser Ablation-ICP-Mass Spectrometry in the Earth Sciences: Current Practices and Outstanding Issues (Sylvester, P., Ed.), Mineralogical Association of Canada (MAC) Short Course Series, v. 40, p. 305-307. 
Keleman, P.B., Hanghøj, K., and Greene, A.R. 2014, One view of the geochemistry of subduction-related magmatic arcs, with an emphasis on primitive andesite and lower crust. In Treatise on geochemistry, second edition, volume 4, The Crust. Edited by R.L. Rudnick, H.D. Holland and K.K. Turekian. Elsevier, Amsterdam, p. 749-806.

Kemp, A.J., and Hawkesworth, C.J. 2005, Granitic perspectives on the generation and secular evolution of the continental crust. In Treatise on geochemistry, volume 3, The Crust. Edited by R.L. Rudnick, H.D. Holland and K.K. Turekian. Elsevier, Amsterdam, p. 349-410.

Keppler, H., Wyllie, P.J., 1991. Partitioning of $\mathrm{Cu}, \mathrm{Sn}, \mathrm{Mo}, \mathrm{W}, \mathrm{U}$, and Th between melt and aqueous fluid in the systems haplogranite- $\mathrm{H} 2 \mathrm{O}-\mathrm{HCl}$ and haplogranite- $\mathrm{H} 2 \mathrm{O}-$ HF. Contrib. Mineral. Petrol. 109, 139-150.

Kerr, A., Ryan, B., Gower, C., and Wardle, R., 1996, The Makkovik province: extensions of the Ketilidian Mobile Belt in mainland North America, in Brewer, T. ed., Precambrian crustal evolution In the North Atlantic region, Geological Society of Canada, v. 112.

Kerr, A., and Sparkes, G., 2008, Diverse styles of uranium mineralization in the Central Mineral Belt of Labrador: an overview and prelimenary discussion: Newfoundland and Labrador Department of Resources Geologic Survey Report 08-1. 
Ketchum, J.W.F., Barr, S.M., Culshaw, N.G., and White, C.E., 2001, U-Pb ages of granitoid rocks in the northwestern Makkovik Province, Labrador: evidence for 175 million years of episodic synorogenic and postorogenic plutonism: Canadian Journal of Earth Sciences, v. 38, p. 359-372, doi: 10.1139/cjes-38-3-359.

Ketchum, J., Culshaw, N.G., and Barr, S.M., 2002, Anatomy and orogenic history of a Paleoproterozoic accretionary belt: the Makkovik Province, Labrador, Canada: Canadian Journal of Earth Sciences, v. 34, p. 1072-1088.

Kontonikas-Charos, A., Ciobanu, C.L., Cook, N., 2014, Albitization and redistribution of REE and Y in IOCG systems: Insights from Moonta-Wallaroo, Yorke Peninsula, South Australia. Lithos. v. 208-209, p. 178-201.

Lawley, C.J.M., Creaser, R.A., Jackson, S.E., Yang, Z., Davis, B.J., Pehrsson, S.J., Dubé, B., Mercier-Langevin, P., and Vaillancourt, D., 2015, Unraveling the Western Churchill Province Paleoproterozoic Gold Metallotect: Constraints from Re-Os Arsenopyrite and U-Pb Xenotime Geochronology and LA-ICP-MS Arsenopyrite Trace Element Chemistry at the BIF-Hosted Meliadine Gold District, Nunavut, Canada: Economic Geology, v. 110, p. 1425-1454, doi:10.2113/econgeo.110.6.1425.

Lottermoser, B.G., 1992, Rare earth elements and hydrothermal ore formation processes: Ore Geology Reviews, v. 7, p. 25-41, doi:10.1016/01691368(92)90017-F. 
Ludwig, K.R., 2003, User's manual for Isoplot/Ex rev. 3.00: a Geochronological Toolkit for Microsoft Excel. Special Publication, 4, Berkeley Geochronology Center, Berkeley, $70 \mathrm{p}$.

Marten, B., 1977, The relationship between the Aillik Group and the Hopedale gneiss, Kaipokok Bay, Labrador: Memorial University of Newfoundland.

McDonough, W., and Sun, S., 1995, The composition of the Earth: Chemical Geology, v. 120, p. 223-253.

Meneghel, L., 1981, The occurrence of uranium in the Katanga System of northwestern Zambia: Economic Geology, v. 76, p. 56-68, doi:10.2113/gsecongeo.76.1.56.

Mercadier, J., Cuney, M., Lach, P., Boiron, M.-C., Bonhoure, J., Richard, A., Leisen, M., and Kister, P., 2011, Origin of uranium deposits revealed by their rare earth element signature: Origin of $U$ deposits revealed by the rare earth elements: Terra Nova, v. 23, p. 264-269, doi:10.1111/j.1365-3121.2011.01008.x.

Migdisov, A.A.,Williams-Jones, A.E.,Wagner, T., 2009. An experimental study of the solubility and speciation of the Rare Earth Elements (III) in fluoride- and chloridebearing aqueous solutions at temperatures up to $300^{\circ} \mathrm{C}$. Geochim. Cosmochim. Acta 73, 7087-7109.

Migdisov, A.A., Williams-Jones, A.E., van Hinsberg, V., Salvi, S., 2011. An experimental study of the solubility of baddeleyite $(\mathrm{ZrO} 2)$ in fluoride-bearing solutions at elevated temperature. Geochim. Cosmochim. Acta 75, 7426-7434. 
Migdisov, A., Williams-Jones, A., Brugger, J., and Caporuscio, F., 2016, Hydrothermal transport, deposition, and fractionation of the REE: Experimental data and thermodynamic calculations, Chemical Geology, v. 439. p. 13-42. 10.1016/j.chemgeo.2016.06.005.

Montreuil, J., Corriveau, L., and Potter, E., 2015, Formation of albitite-hosted uranium within IOCG systems: the Southern Breccia, Great Bear magmatic zone, Northwest Territories, Canada: Mineralium Deposita, p. 293-325.

Montreuil, J., Potter, E., and De Toni, A., 2016, On the relationship between alteration facies and metal endowment of iron oxide-alkali-altered, Sothern Great Bear Magmatic zone, Canada: Economic Geology, v. 111, p. 2139-2168.

Morrison, E. R., 1956, Report on prospecting in area D, Labrador. Newfoundland and Labrador Geological Survey, Assessment File LAB/0182.

Nunn G., A. G., Thomas, A., and Kroght, E., 1985, The Labradorian orogeny: geochronological database, Current research for 1984, Newfoundland Department of Mines and Energy, Mineral Development Division, Report 85-1, p. $43-54$

OECD, 2018, Uranium 2018: Resources, Production and Demand, NEA, no. 7413.

Ootes, L., Goff, S., Jackson, V.A., Gleeson, S.A., Creaser, R.A., Samson, I.M., Evensen, N., Corriveau, L., and Mumin, A.H., 2010, Timing and thermochemical constraints on multi-element mineralisation at the Nori/RA Cu-Mo-U prospect, Great Bear 
magmatic zone, Northwest Territories, Canada: Mineralium Deposita, v. 45, p. 549-566, doi:10.1007/s00126-010-0291-x.

Pearce, J.A., Harris, N.B.W., and Tindle, A.G. 1984, Trace element determination diagrams for the tectonic interpretation of granitic rocks. Journal of Petrology, v. 25, p. 956-983.

Porter, T.M., 2010, Current understanding of iron oxide associated-alkali altered mineralised systems: Part 1-An overview; Part 2-A review. In: Porter, T.M. (Ed.), Hydrothermal Iron Oxide Copper-Gold and Related Deposits: A Global Perspective Advances in the Understanding of IOCG Deposits volume 3. Porter Geoscience Consultant Publication, Adelaide, p. 5-106.

Polito, P.A., Kyser, K.T., Stanley, C., 2009, The Proterozoic, albitite-hosted, Valhalla uranium deposit, Queensland, Australia, a description of the alteration assemblage associated with uranium mineralisation in diamond drill hole V39. Miner. Deposita v. 44, p. 11-40.

Porto de Silveira, C.L., Shorscher, H.D., Miekeley, N., 1991, The geochemistry of albitisation and related uranium mineralisation, Espinharas, Paraiba, Brazil. J. Geochem. Explor, v. 40, p. 329-347.

Potter, E.G., Corriveau, L., Montreuil, J.-F., Yang, Z., Comeau, J.-S., 2014, Geochemical signatures of uraninite from iron oxide-copper-gold (IOCG) systems of the Great Bear magmatic zone, Canada. Geol. Surv. Can Open File 7545, 1 sheet. 
Potter, E.G., Montreuil, J.-F., Corriveau, L., Davis, W.J., 2019a, The Southern Breccia Metasomatic Uranium System of the Great Bear Magmatic Zone, Canada: Iron Oxide-Copper-Gold (IOCG) and Albitite-Hosted Uranium Linkages. In Ore Deposits: Origin, Exploration, and Exploitation, edited by S. Decrée, L. Robb, eds., American Geophysical Union, Geophysical Monograph 242, First Edition, p. 109130.

Potter, E.G., Acosta-Gongora, P., Corriveau, L., Montreuil, J-F., and Yang, Z., 2019b, Uranium enrichment in iron oxide and alkali-altered (IOAA) systems of the Great Bear magmatic zone as revealed by trace element signatures of uraninite, in Corriveau, L., Mumin, A.H., Potter, E.G., eds, Iron oxide-copper-gold and affiliated deposits: GAC Short Course Notes 21.

Putnis, A., 2009, Mineral Replacement Reactions: Reviews in Mineralogy and Geochemistry, v. 70, p. 87-124, doi: 10.2138/rmg.2009.70.3.

Righter, K., Leeman, W.P., and Hervig, R.L., 2006, Partitioning of Ni, Co, and V between spinel-structured oxides and silicate melts: Importance of spinel composition: Chemical Geology, v. 227, p. 1-25.

Romberger, S.B., 1984. Transport and deposition of uranium in hydrothermal systems at temperatures up to $300^{\circ} \mathrm{C}$ : geological implications. In: DeVivo, B., Ippolito, F., Capaldi, G., Simpson, P.R. (Eds.), Uranium Geochemistry, Mineralogy, Geology, Exploration and Resources. Institution of Mining and Metallurgy, London, pp. $12-17$. 
Rudnick, R.L., and Gao, S., 2003, Composition of the Continental Crust, in Treatise on Geochemistry, Elsevier, p. 1-64, doi:10.1016/B0-08-043751-6/03016-4.

Rudnick, R.L., and Gao, S. 2014, Composition of the Continental Crust. In Treatise on geochemistry, second edition, volume 4, the crust. Edited by R.L. Rudnick, H.D. Holland and K.K. Turekian, Elsevier, Amsterdam, p. 1-64.

Salvi, S., Fontan, F., Monchoux, P., Williams-Jones, A.E., Moine, B., 2000. Hydrothermal mobilization of high field strength elements in alkaline igneous systems: evidence from the Tamazeght Complex (Morocco). Econ. Geol. 95, 559-576.

Schärer, U., Krogh, T.E., Wardle, R.J., Ryan, B., and Gandhi, S.S., 1988, U-Pb ages of early and middle Proterozoic volcanism and metamorphism in the Makkovik Orogen, Labrador: Canadian Journal of Earth Sciences, v. 25, p. 1098-1107, doi:10.1139/e88-107.

Skirrow, R., 2010, “Hematite-group” IOCG \pm U ore systems: tectonic settings, hydrothermal characteristics, and $\mathrm{Cu}-\mathrm{Au}$ and $\mathrm{U}$ mineralizing processes, in Corriveau, L. and Mumin, A.H., eds, Exploring for iron oxide copper-gold deposits: Canada and global analogues: Geological Association of Canada, Short Course Notes, No. 20, p. 39-57

Sparkes, G., 2017, Uranium mineralization within the Central Mineral Belt of Labrador: a summary of the diverse styles, settings and timing of mineralization: Newfoundland and Labrador Department of Resources Open Flle LAB/1684. 
Sparkes, G., and Dunning, G., 2015, New U-Pb age constraints on the developement of uranium mineralization within the Central Mineral Belt of Labrador: Newfoundland and Labrador Department of Resources Geologic Survey Report 15-1, 105-113 p.

Sparkes, G., Dunning, G., Fonkwe, M., and Langille, A., 2016, Age constraints on the formation of the iron oxide-rich hydrothermal breccias of the Moran Lake area: evidence for potential IOCG-style mineralization within the Central Mineral Belt of Labrador: Newfoundland and Labrador Department of Resources Geologic Survey Report 16-1.

Sparkes, G.W., Dunning, G.R., Langille, A, 2017, The Michelin deposit: an example of albitite-hosted uranium mineralization within the Central Mineral Belt of Labrador. Newfoundland and Labrador Department of Natural Resources Geological Survey, Report 17-1, p. 219-238.

Stern, R.A., 1997, The GSC Sensitive High Resolution Ion Microprobe (SHRIMP): analytical techniques of zircon $\mathrm{U}-\mathrm{Th}-\mathrm{Pb}$ age determinations and performance evaluation: in Radiogenic Age and Isotopic Studies, Report 10, Geological Survey of Canada, Current Research 1997-F, p. 1-31.

Stern R., 1999, In situ zircon trace element analysis by high mass-resolution SIMS. Ninth Annual V.M. Goldschmidt Conference, 284-285. 
Stern, R.A., and Amelin, Y., 2003, Assessment of errors in SIMS zircon U-Pb geochronology using a natural zircon standard and NIST SRM 610 glass; Chemical Geology, v. 197, p. 111-146.

Timofeev, A., Migdisov, A.A., Williams-Jones, A.E., Roback, R., Nelson, A.T., and Xu, H., 2018, Uranium transport in acidic brines under reducing conditions: Nature Communications, v. 9, doi:10.1038/s41467-018-03564-7.

Tracey, M., 2009, Study of Volcanic and Sediment-Hosted Uranium within the Post Hill Group, Central Mineral Belt Region, Labrador [B.Sc.]: Memorial University of Newfoundland, $137 \mathrm{p}$.

Wardle, R.J. \& Ryan, B and Nunn, G.A.G. \& Mengel, F.C., 1990, Labrador segment of the Trans-Hudson Orogen: crustal development through oblique convergence and collision, v. 37, p. 353-369.

Wilde. A., 2013, Towards a model for albitite-type uranium, Miner 3, p. 36-48.

Wilton, D.H.C., and Wardle, R.J., 1987, Two contrasting metallogenic styles in the Early Proterozoic Upper Aillik Group, Central Mineral Belt, Labrador, Canada: Mineralium Deposita, v. 22, doi:10.1007/BF00206610.

Wilton, D.H.C., and Longerich, H.P., 1993, Metallogenic significance of trace element and $\mathrm{U}-\mathrm{Pb}$ isotope data for uraninite-rich mineral separates from the Labrador Central Mineral Belt: Canadian Journal of Earth Sciences, v. 30, p. 2352-2365, doi:10.1139/e93-204. 
Wood, S.A., 2005.The aqueous geochemistry of zirconium, hafnium, niobium and tantalum, In: Rare-Element Geochemistry and Mineral Deposits, R. L. Linnen and I. M. Samson (Editors). Geological Association of Canada Short Course Notes 17, Geological Association of Canada, p. 217-250. 